\title{
MIDOR】 ISHII
}

\section{HÁBITOS ALIMENTARES DE SEGMENTOS POPULACIONAIS JAPONESES:} HISTÓRICO DA NATUREZA E DIRECÃO DE MUDANCA

\footnotetext{
Tese de doutoramento apresentada $\bar{a}$ Faculdade de Saúde Püblica da Universidade de São Paulo.
}

ORIENTADOR:

Prof. Dr. Yaro RibeIro Gandra

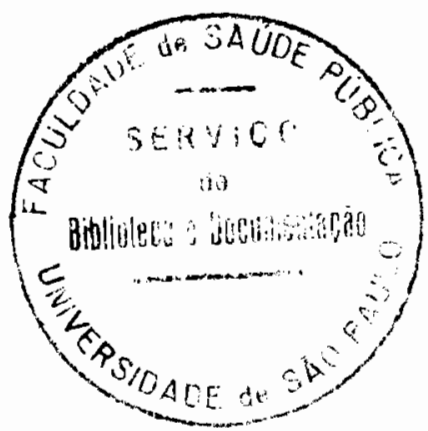


DEDICATÓRIA 
In memoriam da antropóloga MARGARETH MEAD que muito fez para o engrandecimento dos estudos de häbitos ali mentares. 
AGRADECIMENTOS 
- Ao mestre e mentor, Professor Doutor YARO RIBEIRO CANDRA , orientador não só do presente trabalho, mas de toda minha formação profissional, meu especial agradecimento e admira ção.

- A todos os "isseis" e descendentes das colônias ITAPETI, SA KURA-TAKANORI e PARATEI-DO-MEIO que, tão prontamente, colaboraram, fornecendo preciosas informaçōes, sem as quais não se ria possível a realização deste estudo.

- A SHIzUKa MUKaI NACUMO, colega, que participou desde a elaboração do projeto de pesquisa, incorporando, como se fosse uma parte da minha pessoa, com amizade, competência e esforço des medido, minha eterna gratidão.

- Especial agradecimento àquela equipe de campo que nunca esque cerei, onde o tempo só tenderá a aumentar os momentos de sa tisfaçāo, tendo a certeza da qualidade alcançada no levanta mento de dados, motivando o prosseguimento deste estudo.

- As supervisoras de campo, nutricionistas, MARIA KIMICO NISHIDA, CI.ARA SAKANO E TEREZA YAMAMOTO que trilharam,palmo a palmo, a ärea rural, tão difícil de percorrer, transmitindo orientação, entusiasmo e estímulo aos entrevistadores de campo, meu muito obrigado.

- Ao Chefe do Departamento de Nutrição desta Faculdade, Profes sor Doutor DONALD WILSON, pelo apoio inconteste para a finaliza çāo deste trabalho, meu especial obrigado. 
- Aos colegas docentes, ROSA NILDA MAZZILLI, SOPHIA CORNBLUTH SZARFARC, MARLENE TRIGO, IGNES SALAS MARTINS e SERGIO ARAUJo ANTUNES, pelo apoio e estímulo, agradeço sinceramente co movida.

- Ao pessoal de apoio administrativo do Departamento de Nutri ção da casa de Paula Souza e Borges Vieira, nas pessoas de ELISABETH SANTOS SOUZA, SANDRA E.R.JACCOUD MOLINA, FLAVIO ALEXANDRE CONCEIÇAO, ROSELY NOVAES SANTIAGO, JOAO DE PAULO, e demais funcionärios, pela sua presteza.

- AO JOSE CARLOS RODRIGUES que, mui prestativamente, contri buiu na revisão da redação.

- A todos aqueles que, de várias maneiras, concorreram na efetivação desta Tese.

- AO MINISTERIO DE EDUCAÇAO DO JAPAO que outorgou o auxílio financeiro, junto à Universidade Feminina de Hiroshima, para que realizasse esta pesquisa no Departamento de Nutrição da Faculdade de Saúde Pública da Universidade de São Paulo. 


\section{RESUMO}

A coexistência de segmentos populacionais de origem japonesa, no nosso meio,permite uma análise de continuidade da dinâmica dos hábitos alimentares, quando integrada ao sistema ecológico local e sujeitos a tradiçōes culturais nacionais. Na presente pesquisa, ao se tomar os "isseis" que aqui vieram an tes da II Guerra Mundial (IAG), seus descendentes "nikkeis."(D) e 08 "isseis" que aportaram depois da Guerra (IDG), verificouse que a análise das duas geraçōes consecutivas - IAG e D -nos dá idéia da velocidade de mudança dos hābitos alimentares, mes mo quando estes hảbitos estejam influenciados por uma forte pressão cultural. O posicionamento dos IDG a esta evolução, aproxima-os mais dos $D$ do que dos IAG, em razão de jā trazerem uma diversificação alimentar incorporada no Japão de pós-Guerra; a comparação de imigrantes "isseis" com seus descendentes "nikkeis" revela um evidente enfraquecimento do fator cultural de origem na dieta, que, entretanto, não foi abrangente a todos os tipos de alimentos, is to $\bar{e}$, muitos alimentos orientais continuam a ter elevada frequência na alimentação dos $D$, em que pese a presença dos fatores ambientais e culturais ociden tais em seu estilo de vida; mas, se o aspecto cultural teve un papel relevante na permanência de alimentos típicos japone ses, porém, não resistiu à mudança no preparo dos mesmos, onde a incorporação de novos condimentos ( e o abandono dos tra dicionais) teve função de acelerar a aculturação alimentar, di recioriando-os aos hábitos nacionais. 
SUMMARY

The existence of different population segments of ja panese origen among us, permits the analysis of the continuity and the dynamics of feeding habits when integrated to the lo cal ecologic system, under the influence of Brasilian cultural and tradicional factors. In the present paper the study of "issei" that migrated before II World War (BWI) and their des cendents compared to the study of "issei" that migrate after II World War (AWI) showed that the analysis of two consecutive generations - BWI and their descendents - gives us an idea of the speed with which feeding habits changed, even when subjected to strong cultural pressure. The position of AWI in regarding this evolution is closer to BWI descendents than to BWI proper, due to the fact that they had suffered a diversifi cation of feeding habits introduced in Japan after II World War; comparison between the migrant "issei" and their descendents ("nikkei") shows an evident weakening of feeding cultu ral factors that did not, however, comprehend all types of food, that is, many oriental foods still have high frequency in the diet of the descendents; if the cultural aspects did have a relevant role concerning the maintenance of typical japanese foods they did not, however, resist the changes in pre paration of food, where the introduction of occidental seasonings, abandoning the traditional ones, accelerated cultural integration. 
INDICE

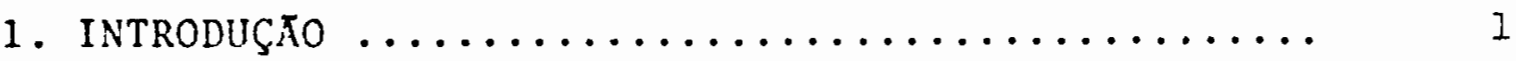

1.1. Gencralidades ...................... I

1.2. Justificativa para estudar um grupo populacio nal de origem japonesa $\ldots \ldots \ldots \ldots \ldots \ldots$

2. ASPECTOS HISTORICOS DO JAPXO $\ldots \ldots \ldots \ldots \ldots \ldots \ldots$

3. BREVE DESCRIÇAO SOBRE A ALTERAÇO DOS IIABITOS ALIMENTARES

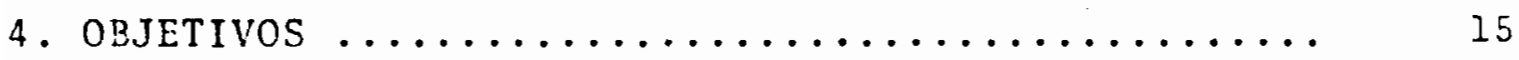

4.1. Geral .......................... 15

4.2. Especificos ..................... 15

5. JUSTIFICATIVA DA ESCOLHA DA RREA DE ESTUDO $\ldots . . .16$

6. DESCRIÇAO DA KREA DE ESTUDO ................ 17

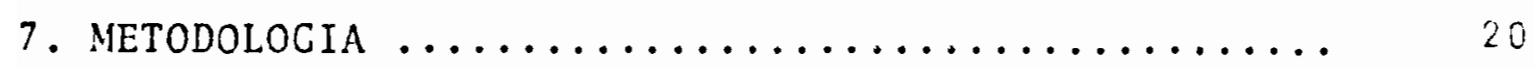

7.1. Formulärios ....................... 21

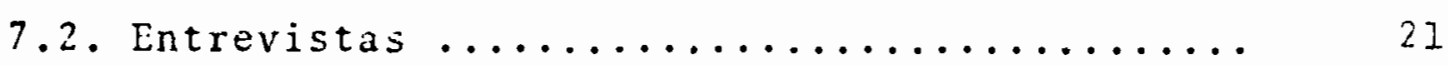

7.3. Critérios de identificação da popuiação pes - 22 quisada

7.4. Inquérito de hábitos alimentares ......... 23 7.4.1. Método ...................... 23

7.5. Critérios adotados para a apuração da freqüên 25 cia de citaçõcs dos alimentos (WAR).......... 
8. APRESENTAÇAO DOS RESULTADOS................. 28

8.1. População em estudo .................... 28

8.1.1. Estrutura familiar.............. 28

8.1.2. Procedência populacional dos chefes-de-. familia........................... 30

8.1.3. Escolaridade dos chefes-de-família.... 30

8.1.4. Anos de residéncia dos chefes-de-famí lia.......................... 30

8.2. Características do meio ambiente da área en es tudo...................................

8.3. Inquérito alimentar................. 35

8.3.1. Análise dos dados de hảbitos alimenta -

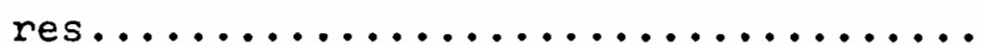

8.3.2. Consumo de alimentos preponderantemente

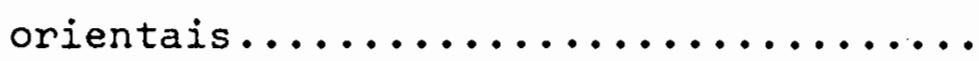

8.3.3. Consurno de alimentos preponderantemente

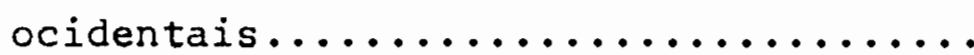

8.3.4. Consumo de verduras e frutas sazo-

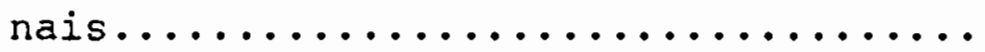

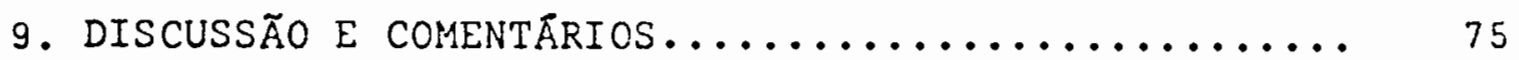

10. CONCLUSÕES $\ldots \ldots \ldots \ldots \ldots \ldots \ldots \ldots \ldots \ldots \ldots \ldots \ldots \ldots \ldots$

11. REFERENCIAS BIBLIOGRĀFICAS............... 82

12. ANEXOS............................. 89 


\section{INDICE DE TABELAS}

TABELAS :

Pāg .

1 - Valor numérico das categorias (diäria, semanal, mensal e eventual) da Unidade Anual de Referéncia (UAR)........ 26

2 - Especificação dos alimentos pertencentes aos grupamen tos alimentares: preponderantemente orientais ( $p$. orientais) e preponderantemente ocidentais (p. ocidentais)....36

3 - Especificação dos alimentos pertencentes aos grupamen tos alimentares: verduras e frutas sazonais............ 38

4 - Resultado da aplicação do teste de Sinal, $\alpha=5 \%$ em cada alimento: preponderantemente orientais ( $p$. orientais) e preponderantemente ocidentais (p. ocidentais), das familias IAG, $D$ e IDG.................... 40

5 - Diferenças absolutas de citações anuais entre famílias isseis antes da Guerra $(I A G)$ e descendentes (D) segundo ordem de grandeza dos alimentos preponderantemente orientais $(p$. orientais) .................... 43

6 - Diferenças percentuais de citaçöes anuais de alimentos orientais, considerando os IAG como 100\%, segundo ordem de grandeza dos $D \ldots \ldots \ldots \ldots \ldots \ldots \ldots \ldots \ldots \ldots \ldots$

7 - Diferenças absolutas de citações de alimentos preponde rantemente orientais ( $p$. orientais) entre famílias isseis antes da Guerra (IAG) e isseis depois da Guerra (IDG), segundo ordem de grandeza............... 47

8 - Diferenças percentuais de citações anuais de alimentos preponderantemente orientais ( $\mathrm{p}$. orientais), tomando as menções das familias IAG como 100\%, segundo ordem de grandeza dos IAG......................... 49 
9 - Diferenças absolutas de citaçōes anuais entre famíli as isseis depois da Guerra (IDG) e descendentes (D), segundo ordem de grandeza dos alimentos preponderantemente orientais ( $\mathrm{p}$. orientais)............... 51

10 - Diferenças percentuais de citaçōes anuais de alimentos orientais, considerando os IDG como 100\%, segundo ordem de grandeza dos $D \ldots \ldots \ldots \ldots \ldots \ldots \ldots \ldots \ldots \ldots$

11 - Diferenças absolutas de citaçöes anuais dos alimen tos preponderantemente ocidentais ( $p$. ocidentais), entre as familias isseis antes da Guerra (IAG) e des cendentes (D), dispostas segundo ordem de grandeza..... 59

12 - Diferenças percentuais de citaçöes anuais de alimentos preponderantemente ocidentais ( $\mathrm{p}$. ocidentais) , considerando famílias isseis antes da Guerra .........6I

13 - Diferenças em nümero $(n)$ absoluto das citações anuais dos alimentos preponderantemente ocidentais ( $p$. ocidentais), entre as familias isseis: antes da Guer ra (IAG) e depois da Guerra (IDG) ...............63

14 - Diferenças percentuais das citaçōes anuais dos alimentos preponderantemente ocidentais ( $\mathrm{p}$.ocidentais), considerando as famílias IAG como $100 \% \ldots \ldots \ldots . \ldots 6$

15 - Diferenças em número absoluto das citaçöes anuais dos alimentos preponderantemente ocidentais ( $p . o c i-$ dentais), entre as famílias isseis depois da Guerra (IDG) e dos descendentes (D), segundo ordem de gran-

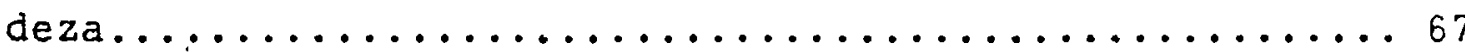

16 - Diferenças percentuais das citações anuais dos ali mentos preponderantemente ocidentais ( $p$. ocidentais), considerando as familias IDG como $100 \%$............69 
FIGURAS:

I - Mapa do Estado de São Paulo e locãlização da área em estudo Ia. Região Administrativa da grande São Paulo, Municipios de Mogi das Cruzes e Guararema; 3a. Região Administrativa do Vale do Paraíba, Mu-

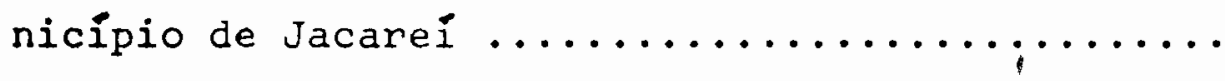

2 - Pirâmides populacionais:IAG(A); $D(B)$; e IDG(C) de população em estudo, $1981 \ldots \ldots \ldots \ldots \ldots \ldots$

3A- Distribuição da procedēncia dos chefes-de-famỉia IAG (1924 - 1941), segundo Região do Japão .....

3B- Distribuiçāo da procedência dos chefes-de-família IDG (1953-1971) em porcentagem, segundo Região do Japão .........................

4 - Distribuição da procedència, por local de nascimento, dos chefes-de-família descendentes segundo Região Administrativa do Estado de são Paulo

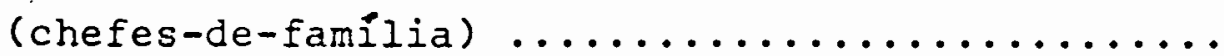

5 - Apresentação gräfica os alimentos preponderante mente orientais com frequéncia anual de mençōes, de uma vez por semana ou mais ao ano (em percen tual), segundo os grupamentos familiares: IAG(1);

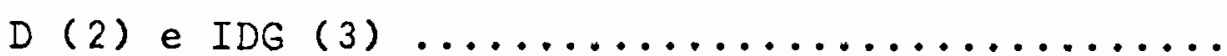

6 - Apresentação gräfica dos alimentos preponderantemente ocidentais com frequēncia anual de mençōes, uma vez por semana ou mais ao ano (em percentual), segundo os Erupanentos familiar: IAG(1); $D(2) \in$

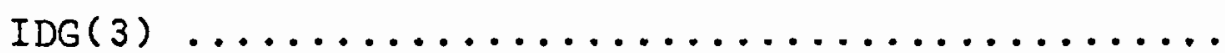

7 - Apresentação gräfica das verduras mencionadas pelas familias pesquisadas IAG(1); $D(2)$ e IDG(3), de consumo usual durante $\circ$ ano $\ldots \ldots \ldots \ldots \ldots \ldots$

8 - Apresentaçäo gräfica das frutas mencionadas pelas famílias estudadas - IAG(1); $D(2)$ e IDG(3), daque las de consumo usual durante 0 ano. 
1 - Formulário populacional - alimentar ............. A-1

2 - Formulário meio ambiente ................. A-12

3 - Conceituação de Fundação IBGE .................... A-15

4A- Distribuição do número de frequencia dos alimentos preponderantemente orientais em diäria (D); semanal (S) ; mensal $(M)$ e eventual (E), segundo erupo familiar IAG,

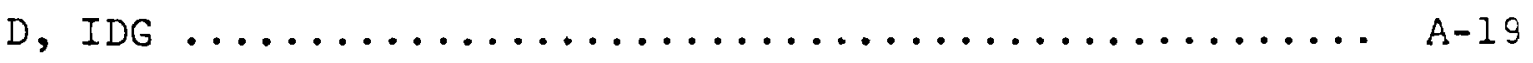

4B- Lista de fatores específicos ( $f_{e}$ ) dos alimentos preponderantemente orientais em diēria (D); semanal (S); men sal (M) e eventual (E), segundo grupo familiar IAC, D e

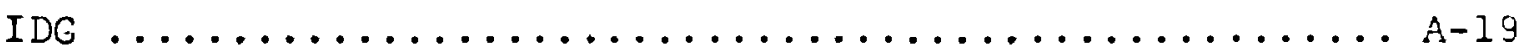

5A- Distribuiçāo do nümero de frequència dos alimentos preponderantemente ocidentais em diäria (D); semanal (S) ; mensal $(M)$ e eventual (E), segundo grupo familiar IAG,

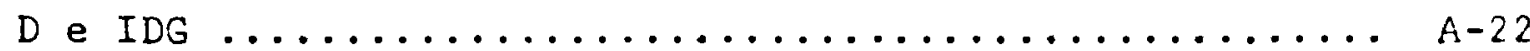

55- Lista de fatores especificos ( $f_{e}$ ) dos alimentos preponderantemente ocidentais eri diäria (D); semanal (S); men sal (M) e eventual (E), segundo grupo familiar IAC, D e

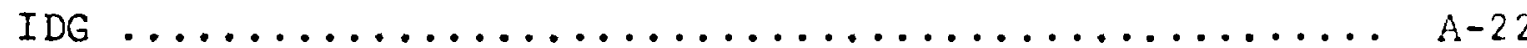

6 - Listagem dos alimentos preponderantemente orientais, com respectivas frequéncias mécias anuais (dias), desvio pa drão, em ordem de grandeza, e nümero de dias da fre quência anual ( $f . a$. ) de cada alimento mencionado pelos grupamentos familiares: IAG, $D \in I D C \ldots \ldots \ldots \ldots \ldots A-26$

7 - Listagem dos alimentos prefonderantemente ocidertais, com respectivas frequéncias médias anuais (dias), des vio padrão, em orden de grandeza, e número de dias da frequência anual ( $f . a$. ) de cada alimento mencionado pelos Erupamentos familiares IAG, D e IDG ........... A-27 
8 - Idade média dos chefe -de-familia dos grupos fa miliares IAG, $D$ e IDG..................

9 - Distribuição percentual do grau de escolaridade dos chefes-de-família, estratificados em IAG, D

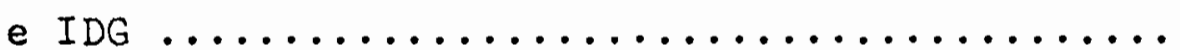

10 - Tempo de residência dos chefes-de-familia, estra tificados em grupos IAG, D e IDG, nos Municipios

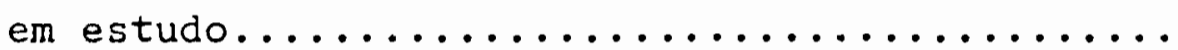

$A-30$

11 - Distribuição da área total das propriedades em alqueire e área utilizada para produção, segundo as familias, $1981 \ldots \ldots \ldots \ldots \ldots \ldots \ldots \ldots \ldots$

12 - Tipos de produçāo agrícola , 1981........... A-32

13 - Condiçōes de posse-da-terra $A-33$

14 - Tipos de construção de moradia das propriedades rurais estudadas

15 - Distribuição do número de cômodos das residên cias, segundo as familias

16 - Distribuição dos tipos de abastecimento d'água, revestimento do poço e instalação da bomba-d'àgua, segundo as familias.

17 - Número de sanitários, com e sem descarga, segun do localização dentro e fora de casa, entre as familias estudadas A-36

18 - Glossärio de alimentos orientais ............ 
1. INTRODUÇĀO

1.1. Generalidades

Nos idos da década de 40 , quando surgiram

os primeiros programas de nutriçāo aplicada com o fim de melhorar - estado nutricional de populaçōes, os especialistas em nutri ção humana notaram que os beneficiārios apresentavam resistēncia em aceitar os alimentos distribuidos para o combate à desnutriçäo. Verificou-se, entāo, que os indivĭduos escolhiam os alimentos, nāo pelo seu valor nutricional, mas sim em decorrēn cia do comportamento cultural. Naquele periodo, apesar da ciẹn cia da nutrição haver alcançado um patamar alto de conhecimentos, ainda, carecia de maior vinculação com os estudos scbre a conduta humana, frente à questão alimentar ${ }^{2}, 3,36$

Para preencher esta lacuna, criou-se, em 1941, nos Estados Unidos, a comissāo sobre Hābitos Alimentares do Conselho Nacional de Pesquisa da Academia Nacional de Ciencias, sob a direçāo da antropóloga Margareth Mead. Foi-lhe confiada a tarefa de reunir dados dispersos em diferentes àreas das ciências, no que se referia a häbitos alimentares e analisar, do ponto de vista cultural, o comportamento humano ante uma mu dança alimentar, partindo da premissa de que qualquer hábito alimentar é parte inseparável do estilo de vida. 3,37

Se, por um lado, o conhecimento dessa relaçäo entre o estado de saūde individual e os hábitos alimentares ainda não está consolidado, por outro lado, o comportamento ali mentar do indivíduo tem uma dinämica que evolue conjuntamente com os usos e costumes da comunidade à que pertence, exigindo contínuo desenvolver de pesquisas.

Realizar o estudo de häbitos alimentares signi fica, antes de mais nada, adentarar na histónia do patrimōnio 
cultural

da comunidade e, deste modo, reconstituir o processo de sua emergēncia e das diferentes fases de sua evolução, incluindo as induçōes resultantes da suplementação alimentar. Não se trata, contudo, de uma reconstituição cronolögica, pois o objetivo pre cípuo è apreender o conjunto das relaçöes estabelecidas entre hãbito e contexto geogrāfico e söcio-cultural mais abrangente no qual se insere, exigindo maior domínio das informaçōes detec tadas anteriormente, ampliando sua representatividade e importāncia. $1,18,20,26$

Por esta razāo, à medida que se multiplicam os estudos de mudanças de hábitos alimentares mais se aproxima das metas almejadas, contribuindo para a obtenção do bom desempenho, no que tange a programas de alimentaçāo, bem como, na pre servação da saúde da população-alvo.

1.2 Justificativa para estudar um grupo populacional de origem japonesa

Ao se pretender realizar estudo sobre mudança de hábitos alimentares, antes de tudo necessita-se determinar o gru po populacional especifico que possa oferecer informaçöes quanto às diferenças existentes dentro da comunidade à qual pertence. 25 $\operatorname{REID}^{42,43}$ considera o estudo em grupos êtnicos de grande interesse por apresentarem um campo fërtil, promissor e emergente, onde se pode analisar um comportamento na sua pleni tude, condicionando-o à variävel de mudança ambiental. 0 autor preconiza a pesquisa em migrantes intercontinentais, fazendo levantamentos epidemiolögicos de algumas doenças näo-transmissíveis e comparä-los com os dados de seu país de origem. Isto traria contribuiçäo para se detectar as condiçōes histōricas da natureza da doença. Há referências não sistematizadas de estudos pioneiros, desenvolvidos na Inglaterra e Estados Unidos. Os japone- 
ses, residentes nos Estados Unidos, foram objeto de estudos nes se sentido, correlacionando doença com mudanças de häbitos ali mentares $28,46,48,52$.

O Brasil, desde 1908 , sendo país receptor de imigrantes japoneses, apresenta, no seu bojo populacional, os migra dos que aqui aportaram antes da II Guerra Mundial e aqueles que vieram pös-Guerra, genericamente denominados de "issei"*. Há ain da, também, um outro grupo integrado por descendentes, brasileiros natos, oriundos dos "isseis", que, na colônia japonesa, são designados com o termo "nikkei" $\$ 8,39,44$

Ao ater-se no estudo desta população de origem jä ponesa, pretende-se obter informaçōes sobre comportamento alimen tar em diferentes estägios da adaptação cultural, pois, conta-se com trés categorias do mesmo segmento populacional: 1. os "isseis" pré-Guerra, possuidores de herança cultural do Japāo, baseada na tradição oriental secular e estabelecidos há mais de 40 anos no Brasil; 2. os "isseis" pōs-Guerra, apresentando, em sua bagagem cultural, o Japäo, com influēncia ocidental e estabelecidos no Brasil hä cerca de 20 anos, e, 3. os "nikkeis", brasileiros por nascimento, mas criados em ambiente ainda sob forte cultura dos "isseis" antes da Guerra.

Verificar os hābitos alimentares desses três seg mentos da populaçāo de origem japonesa, no território nacional, será o cerne desta pesquisa, dando, assim, continuidade ao estudó iniciado e apresentado como dissertação de Mestradơ.4

Issei-vocabulo japones, significando primeira pessoa da geração e com naturalidade japonesa.

** Nikkei-vocábulo japonês, significando pessoa de origem japone sa nāo diferenciando as geraçōes a que pertençam, a partir da segunda geraçāo ou todos os descendentes japoneses, nascidos no ultramar. 


\section{ASPECTOS HISTORICOS DO JAPAO}

Em nossos comentārios mencionaremos, ainda que brevemente, a passagem do antigo regime ao moderno estado industrial e movimento migratório ao exterior.

Discorrer uma fase histōrica do desenvolvimento sōcio-cultural do Japāo è de importāncia para este estudo, a fim de compreender os fatores seletivos que estimularam o movi mento migratório ao hemisfërio ocidental, bem como situar o es tāgio do momento histōrico japonēs, ao qual pertenciam os "isseis" 4,21,39,44,49.

O Japäo, entre 1603 a 1868, passou pelo período do shogunato, sob a égide dos shoguns ou governadores milita res, que ordenou o fechamento dos portos, praticamente isolando -o. A classe dominante, constituida pelos shoguns e guerrei ros samurais, compunha-se de 400.000 famílias, representando cerca de 78 da população total da época. As atividades produti vas do País eram exercidas pelo restante $93 \%$ da populaçāo, dividida entre camponeses, artesōes e mercadores que eram muito pobres. Os camponeses, apesar de serem ignorantes e analfabe tos, estavam em estrato de situaşäo social superior ao dos artesōes e mercadores, uma vez que eram responsāveis pelo suprimento alimentar da naçāo, principalmente o arroz, cuja produ ção indicava a pujança econōmica de cada domínio.

- arroz era o alimento básico para a classe domi nante, enquanto a maioria da população trabalhadora recorria a outros cereais e tubérculos, embora excepcionalmente.

Em 1853, os Estados Unidos forgaram a aber tura ao mercado internacional, liberando o mercado japonês para a indústria americana e, posteriormente, para alguns ou tros países (Inglaterra, Rússia e França). Este episödio marcou o fim do shogunato e o surgimento de uma economia monetá - 
ria e a emergēncia de uma nova classe de mercadores, até então sem prestígio. Porẻm, muitos shoguns aderiram a essa nova realidade, encorajando as atividades industriais e comerciais, dentro dos seus domínios e sob seu controle. Assim, desenvol veram-se as indūstrias manuais de fiaçāo e tecelagem, porcelana e "papel-de-arroz". Nessa época, os produtos exportāveis eram notadamente o chā, a seda e os produtos têxteis.

No contexto da cultura japonesa, a substituição do shogunato pelos padrōes ocidentais, firmou-se a partir da ascenção do Imperador Meiji (1868-1912). O Japão sofreu transformaçōes marcantes, tanto políticas quanto econōmicas e so ciais. Neste período, o idealismo pela igualdade de classes vi gentes, no mundo ocidental, foi muito enaltecido, eliminando a antiga estratificação social rígida, mobilizando todo o País e contribuindo para o fortalecimento de sua unidade.

Em 1871, O Estado, com o objetivo de combater o analfabetismo e a ignorāncia da população, criou o Ministērio de Educaçāo e, logo no ano seguinte, implantou o sistema de en sino compulsōrio de 18 Grau para as crianças de 6 a 14 anos de idade.

Em 1890, O Imperador Meiji decretou a "Rescrito Imperial* sobre a Educaçāo", vigente atē 1945, servindo de guia à formação moral e cívica do povo japonēs. Nele continha a absoluta fidelidade ao trono, normas de convivēncia (obedien cia aos genitores, harmonia entre cônjuges, compreensäo entre amigos, etc) e amor à Pátria. Estas normas de conduta propor cionaram o desenvolvimento de um regime monárquico centralizado, onde a figura do Imperador representava o Senhor Supremo da Naçāo.

* Rescrito Imperial 49 sgnifica resolução do rei, comunicada por escrito. 
Esse esforço, empreendido pelo Estado ao siste ma educacional, pnopagou-se rapidamente, facilitando a introdução das culturas e costumes ocidentais no Japäo, enquanto que, ao mesmo tempo, coexistia o culto ao Imperador e aos va-. lores tradicionais.

Na realidade, no período de 1870 a 1910 , as condições de vida no País foram bastante difíceis para os con tingentes de campo. Os camponesas de servidores dos shoguns, com a "reforma agrária", de posse de terra, passaram a ser cidadāos comuns, com todos os encargos de sobrevivéncia de sua família, embora com renda insuficiente. Esta situaçāo provocou o éxodo rural, transferindo-os para as indústrias tradicio nais locais, sob baixo salário, e, eventualmente, reforçavam seus rendimentos com o amanho da terra, dentro das possibilida des encontradas. Esse baixo poder aquisitivo, de numerosa parte da população, resultou em mercado interno pouco estimulante para o consumo dos produtos manufaturados, fato que induziu a industria nascente a se orientar mais ao mercado externo.

A receita, proveniente da exportaçāo desses pro dutos, somada com a arrecadaçāo do imposto territorial muito passado, foi destinada à aquisiçāo de bens de capital para a grande indústria, resultando em concentraçäo de renda nesse sẹ tor. Estabeleceu-se, com isso, a instabilidade social daquela população marginalizada por esse processo industrial de passagem ao capitalismo, conduzindo a muitas revoltas populares. '0 grande nümero de pequenos proprietários rurais, pela insolvēncia dos impostos do uso da terra e com a exigēncia de pagamento em dinheiro, foram obrigados a se tornarem arrendatários dos grandes proprietários ou, entāo, foram expulsos do seu meio rural pela hipoteca de sua propriedade, relegando-os à uma situação de penūria. 
A primeira experiência de emigraçäo, ocorreu em 1868, entre jōvens desocupados do porto de Yokohama com destino às ilhas de Guan e Havai. Devido às péssimas condiçōes de tra balho, muitos perderam a vida, o que levou à sua proscrição.

Observa-se que com o advento da época Meiji, hou ve forte crescimento populacional, mormente a partirde 1872 , mediante a organização mēdico-hospitalar, a vacinação e a assis tēncia comunitāria para a populaçāo em geral. Esse aumento popu lacional veio reforçar a necessidade de absorver a mäo-de-obra que, impedida de se dirigir ao exterior, forçou a mobilizaçāo in terna, realocando-se os samurais que estavam sem atividade desde a queda do regime anterior e, posteriormente, os camponeses semterra para o norte do territörio japonês, ainda devoluto e inóspito, garantindo sua colonizaçäo e garantindo as fronteiras ido País.Prosseguiu-se dali, a corrente migratōria ao exterior para Rússia Asiātica, China, Manchüria e Corëia". 39,44

o movimento migratório, desencadeado para o exterior, direcionou o tipo de imigração por período de tempo determinado, mediante contrato entre governos, a saber: Estados Unidos, 1868-1924; Canadā, 1877-1925; Austrālia, 1883-1925 e para América do Sul, o primeiro país a receber foi o Peru, 18991921.

o movimento migratōrio japonēs, direcionado ao Brasil, iniciou-se a partir de 1908, porēm, somente veio inten sificar-se a partir da dēcada de 20 , devido à restriçāo imposta por outros países, tradicionalmente receptadores de imigrantes:

* Cronologicamente, esse movimento migratório internacional sucedeu-se ao longo de trēs reinados do trono japonēs. Iniciou-se na era Meiji (1868-1912), toda a seguinte e curta era Taisho (1912-1926) e ao longo da atual era Showa, reinando o Imperador Hiroito, desde 1926 até os dias de hoje. 
Assim, o registro de maior entrada dos japoneses. no Brasil, foi durante o período de 1920 a 1934, atē a implantaçāo : do "Sistema de Quotas", quando já representavam 68,6q dos ingressantes no País.

Os imigrantes japoneses, atē 1920, eram de ori gem ruricula, menos afeitos à mudança cultural do prōprio país de origem, porém, mais prōximos do impacto da era Meiji. Os que para aqui vieram, no período de 1920 a 1930, foram aqueles atingidos pela depressāo econômica, apōs a deflagração da I Guer ra Mundial com a quebra das grandés empresas no Japão.

os japoneses, no território brasileiro, inicial mente foram enviados à área rural, em colônias isoladas, rústicas e etnocéntricas. A expectativa de retorno levou -os a transferirem ${ }^{\approx}$ seus filhos muitos dos seus valores originais. Du rante a II Guerra foram pressionados pelo Governo e Empregadores a assumir a instrução bāsica brasileira, forçando sua acul turaçāo, enquanto se sustava a corrente migratōria japonesa.

Apös a II Guerra Mundial, reiniciou-se a corren te emigratória, formada pelos japoneses criados numa outra rea lidade, que conviveram com a Guerra e a destruiçāo de sua cultura, face à proibiçāo do "Rescrito Imperial", emanado do Impe rador Meiji, pelas forças de 0cupação. São produtos de um país já extremamente ocidentalizado, de jóvens à procura de novas esperanças, deslocando-se do meio competitivo de reconstrução do País e daqueles repatriados da China, Manchūria e Coréia., desacostumados da cultura pätria. Somente o surto industrial pós-reconstruçāo, a partir de 1963, diminuiusensivelmente este movimento ao exterior. Possuem instrução mais acurada, com visāo mais ampla do mundo ocidental, diferente dos seus antecessores com concentraçäo restrita à cultura japonesa e com idéias esteriotipadas referentes ao mundo ocidental. 
3. BREVE DESCRIÇÃO SOBRE A ALTERAÇÃO DOS HÄBITOS ALIMENTARES NO JAPAO

Embora, seja escassa na literatura ocidental, a descrição detalhada sobre os hábitos alimentares no Japão, é necessário, ao presente estudo, tecer algumas consideraçōes neste sentido. $23,32,33,34,40$.

OISO 41 e GALLAGHER 14 , ainda que suscintamente, abordam o transcurso do padrão alimentar no Japão, nestes últimos 70 e 80 anos.

Os referidos autores consideram que a consolidação da verdadeira mudança alimentar, de eminentemente oriental, ao passar para un estāgio mais ocidentalizado, veio somente ocorrer na década de 60. Isto, justamente, no momento em que os resultados do Inquérito Nacional de Alimento : registrou o declínio do consumo per capita-dia do arroz e do acentuado abandono de alimentos considerados habituais da população japonesa, tais como: cevada, centeio, tubérculos, shoyu e misso, cedendo lugar aos alimentos próprios do mundo ocidental: carre, ovo, óleo, gordura e açúcar.

Entretanto, o fator casual desta modificação al mentar desencadeou-se no período correspondente a dois anos, antes e depois do fim de II Guerra Mundial, quando toda extensão territorial enfrentou a maior crise alimentar, provocada pela falta de gêneros alimentícios. A população foi submetida a um drástico racionamento e a produção nacional de arroz enca pada pelo Governo.

Dentre as citaçōes de doenças preocupantes de origem nutricional da população, na época, aparecem a desnutrí ção protéico-energética, anemia além de outras doenças carenci ais.

O saldo positivo desta situação de penúria foi que a população retrógada à mudança alimentar, diante do impac 
to da fome, veio incluir na dieta familiar, logo ao findar a Guerra, os alimentos estranhos ao habitual, enviados pela Orga nização de Socorro. Constatou-se que o consumo energētico diārio não excedia de $1800 \mathrm{kcal}$, mesmo computando as calorias pro venientes dos alimentos recebidos do Exterior.

No entanto, a preocupação com o estado nutricio nal do povo japonēs jā era motivo de consideraçāo na era Meiji. Assim, em 1911, o médico Tadasu Saiki, ao retornar dos Estados Unidos para o Japāo, apōs findar os estudos da ciēncia da nutrição, iniciou esforços para melhoria das condiçöes nutricionais da população.

Em 1914, Saiki criou o Instituto de Pesquisa de Nutrição, em carāter particular, visando dois objetivos: 1. de senvolver pesquisas científicas e 2. popularizar os conherimen tos de nutrição. Para tanto, formou uma equipe de pessoal trei nado, cuja atividade consistia em mudar o hābito de consumir as três refeições principais do dia, à base quase exclusiva de arroź, que respondia por $75 \%$ das necessidades energēticas diä rias $^{32}$ para duas somente e a terceira, à base de trigo e, ain da, incentivar o consumo de produtos de soja, fontes protéicas de origem animal e verduras nas refeições.Havendo a necessida de de pessoal melhor treinado, às suas expensas, fundou a primeira Escola de Nutrição, em 1925, com vistas a desenvolver atividades de nutrição nos serviços de atendimento püblico das províncias, fābricas, hospitais, escolas e prisōes. As ativida des de nutrição obtiveram o reconhecimento de sua importāncia somente em 1934, quando os tēcnicos de nutriçäo implantaram a cozinha comunitäria, numa área rural, ao norte da ilha principal, para programas de emergència face ao surto de fome. Razão pela qual, por Decreto, em 1937, as atividades de nutrição tornaram-se obrigatórias em todas as unidades de saúde do País, 
a fim de combater o alto consumo de hidratos de carbono e res trito em proteínas, gorduras e vitaminas.

A contribuiçāo preponderantemente dos técnicos de nutrição, logo após a Guerra, foi sua atuaçāo no sentido de esclarecer os mētodos de cocçāo dos alimentos da cozinha ocidental, envolvendo diretamente a populaçāo, fazendo-a participar nos programas de alimentação. A escola serviu muito para tal fim, com convocaçāo obrigatöria, por rodizio, das mães de alunos, para o preparo de almoço escolar.Carros-ambulantes para demonstração da culinäria ocidental, cobriram toda a comunidade, inclusive a ärea rural. Alëm dessas atividades mencionadas, desenvolveu-se o programa de incentivo ao consumo de alimentos enriquecidos 32,41

No entanto, as orientações nutricionais, emana das do Instituto Nacional de Nutrição, somente foram acolhidas em 1945, fazendo com que o povo japonēs iniciasse a diversifí cação de sua alimentação tradicional, apesar de ter "fome de arroz". 14

O gräo arroz tem, para o japonēs a conotaçäo secular de "alimento nobre" e o povo atribui-lhe alta conside raçāo.

Entretanto, o arroz nem sempre constituiu a ba se da dieta de todo povo japonès, variando, segundo a localidade geogräfica do País. Assim, nas äreas de rizicultura, o arroz participava da dieta, porēm, por não ser abundante, mui tas vezes, este era misturado com cevada e centeio.Nas regiōes montanhosas, eram consumidos, tão somente, o sorgo e painço. Os alimentos bäsicos tinham como acompanhantes, os pratos pre parados com verduras muito cozidas em shoyu, conserva (tsuque mono) de nabo ou de vegetais folhosos e sopa de misso. Em algumas localidades, o arroz era substituído por tubérculos (ba tata-doce e inhame), sendo os pratos acompanhantes, a soja e 
seus derivados (tofu, ague e misso). Nas regiōes litorâneas, nestes pratos complementares apareciam os peixesm mariscos e algas marinhas. Em geral, somente e. ocasiōes especiais, eram utilizados os pescados e outros produtos do mar, ovos, leite, óleo e gorduras. O cerceamento a estes alimentos, deve-se, prin cipalmente, ao fator financeiro familiar. 41

Portanto, até a ēpoca da II Guerra Mundial, a alimentação dos japoneses era quase que monōtona, rica em carboidratos e verduras, carentes, entretanto, de proteínas, lipídios e vitaminas.

JUDD $^{27}$, referindo-se aos efeitos das influên cias externas sobre os hābitos alimentares dos japoneses, durante o período correspondente a dez anos de ocupação do Japão pelas Forças Armadas Americanas, comenta que as consequencias foram superficiais e quase que Iimitadas. Pois, a essência da preferēncia alimentar ainda recaia naqueles tradicionais peixes, mariscos e outros produtos de mar em vez de carnes. As principais mudanças dos häbitos alimentares consistiram no au mento do consumo de leite (em pó, importado), aumento do uso de carne bovina, na forma de bife, grande consumo de trigo, maior procura de arroz enriquecido com tiamina (contendo gérmem) e significativo acréscimo de consumo do açúcar.

Sendo o sabor doce muito valorizado pelos japone nes, houve a adoção do uso de açūcar nas formas mais diversas, notadamente, nas bebidas quente e fria, refrigerantes aromati zados com sabor artificial de frutas, balas, goma de mascar, bolos e pão-doce e doces ocidentais e orientais, à base de fei jāo.

Verificou se marcante influēncia das cozinhas fran cesa e americana,logo após a assinatura do Tratado de Paz, com expansão de restaurantes especializados em pratos aromatizados com ervas, molhos e frituras. A seguir, este impulso in $\underline{i}$ 
cial de expansão dos restaurantes da cozinha internacional re traiu-se, voltando à cozinha japonesa.

Uma das razöes que veio contribuir, profundamen te, na modificação alimentar no Japão foi, sem dúvida, a ’implantação de nova estrutura fundiäria, imposta pelas Forças de Ocupação Americana, eliminando as grandes propriedades rurais, deversificando a exploração da terra e induzindo à tecnologia moderna agrícola, visando a produtividade por àrea plantada . Esta reforma agrária resultou positiva a partir da década de 50 e, em 1966, o Japão conseguiu elevar a produção de arroz em nível de auto-suficiéncia. A diversificação programada de produção agrícola veio favorecer a oferta hortifrutigranjeira à população. 14

Como anteriormente mencionado, o desenvolvimento de programas de suplementação alimentar nas escolas, nos serviços comunitārios em fábricas e escritórios, ao incentivar - consumo de pão e macarrōes como substitutivo do arroz, na época de dificuldade, veio induzir. ao subseqlente consumo de produtos lácteos (manteiga e queijo), margarina, gelēia, ve getal crú, ovo, embutido e óleo comestível.

Como o povo desconhecia, até então, o mētodo de cocção da cozinha ocidental, os tẻcnicos de alimentação centra ram sua atenção no treinamento e divulgaçāo do preparo de novos alimentos. Para facilitar o uso de alimentos ocidentais, promoveu-se a industrialização dos produtos processados à base de trigo: salgados, massas para frituras, bem como, a carne do tipo "hamburger" e salsicha. Estas novas modalidades de alimen to atingiram, notadamente, a populaçāo jóvem. Por volta de 1951, este recurso alimentar industrializado começou a acele rar o consumo, coincidindo com a reconstrução econōmica do Japäo $23,32 \cdot 33,41$

Os estudos epidemiológicos de algumas doenças 
não transmissiveis indicam que houve transferēncia das doenças carenciais para aquelas consideradas mais próprias ao mundo ocidental: doenças cardíacas, diahetes melito e alguns tipos de neoplasmas malígnos, considerando como um dos fatores causa is a mudança de comportamento alimentar dos japoneses. Concretamente, em 40 anos (1935-1975), ao se observar a ingestāo ali mentar per capita dia, notam-se as seguintes diferenças: 0 con sumo de arroz decaiu em $35 \%$ e o dos tubërculos, em 50\%. Ao con trário, houve o incremento na ingestão de öleos e gorduras em 7 vezes, do açūcar em 1,3 vezes e das carnes em 12,5 vezes. Os vegetais, as frutas $e$ as algas marinhas, neste periodo conside rado, mostraram-se mais estacionārios, com discreta elevação de consumo. 41

Pode-se concluir, pelo exposto, que, atè a eclo são da II Guerra Mundial, os hābitos alimentares no Japão eram extremamente conservadores, com característicasorientais, e os japoneses depois da Guerra, pelas circunstâncias que $\circ$ País es tava atravessando e as condições sōcio-econômicas e culturais estavam favoráveis às modificaçōes alimentares, fez com que a alimentação se aproximasse à semelhança dos häbitos alimentares da sociedade ocidental. 
4. OBJETIVOS

São objetivos do presente trabalho:

4.1. Geral

Conhecer e caracterizar a alimentação de famílias, segundo três tipos de segmentos populacionais de um grüpo ètni co, com assentamento espacial no ambiente rural paulista.Estes três tipos de segmentos foram constituídosde "isseis" antes da Guerra, descendentes e "isseis" depois da Guerra.

\subsection{Especificos}

a) Comparar os hábitos alimentares das famílias imigrantes japonesas ("isseis"), que aportaram no País antes da II Guerra Mundial, com os daquelas familias de seus descendentes ("nikkeis").

b) Comparar os häbitos alimentares dos imigrantes jạ poneses, estabelecidos no País antes da II Guerra Mundial, com os dos que para aqui vieram pōs-Guerra.

c) Comparar os häbitos alimentares das famílias des-i cendentes com os dos "isseis" de pós-Guerra.

d) Analisar os häbitos alimentares dessas famílias , assim estratificadas, segundo alguns determinantes causais.

e) Delinear estratégia de estudo para aferir a mudan ça de comportamento alimentar. 
5. JUSTIFICATIVA DA ESCOLHA DA AREA DE ESTUDO

A ärea para se desenvolver este estudo deveria contar com algumas condições específicas para poder-se atingir os objetivos.

Assim, a comunidade deveria ser de tipo conglo merado isolado, com atividade produtiva semelhante, tanto do ponto de vista histórico quanto econômico, porém, que não estivesse em fase de estagnaçāo, preferentemente de proprietā rios de terra. e podendo contar com estratos populacionais propostos no objetivo do estudo e, ainda, estar assentado na àrea hã mais de 5 anos.

A área que melhor se enquadrava nessas condições foi encontrada em três colônias rurais japonesas, circun visinhas, na Zona Leste da Região Metropolitana de São Paulo. Seus habitantes eram, na maioria, donos de pequenas glebas de terra, com clima e temperatura amenos, a $700 \mathrm{~m}$ acima do nível do mar. Históricamente, nesta ārea, desde 1919, explorava-se a horticultura e a fruticultura.Tanto isto è verdade que, mais recentemente, tornou-se um centro hortifrutigranjeiro, abaste cedor das cidades de São Paulo e Rio de Janeiro.

Pelo visto, a fixação do elemento nipônico, na ărea, è antiga e a produção agrícola é tradicional.

As três colônias, da ârea escolhida, foram formadas pela aquisição do loteamento de glebas de terra,em 1961. A exploração da terra é semelhante em toda a região, basica mente hortifutigranjeira. 
6. DESCRIÇÃO DA ÅREA DE ESTUDO

As três colônias inclứdas no estudo, localizamse ao longo da Rodovia Federal Presidente Dutra, nos municípios limitrofes da la. Região Administrativa da Grande São Paulo (Mu nicípios de Mogi das Cruzes e Guararema)e da 3a. Região Adminis trativa do Vale do Paraíba (Município de Jacareí), Estado de São Paulo, distando da Capital entre 50 e $70 \mathrm{~km}$ (FIGURA 1).

0 inicio da ocupação desta região coberta pela pesquisa, tem iregistro em época distante e histórica de sāo Paulo. E considerada como o berço das mais antigas povoaçōes do planalto paulista, de onde partiram as entradas e bandeirantes, no fim do século 16, para o desbravamento do sertão brasileiro.

Devido à localizaçāo entre duas cidades, São Paụ lo e Rio de Janeiro, era passagem obrigatória àqueles que deman dassem às duas Capitais desde a época do Brasil Colonial. Era, tambẻm, por esta região que se transitava em direçāo ao litoral. Suas culturas agrícolas tradicionais eram o milho, a mandioca e feijão. 22

A instalação dos japoneses iniciou-se em 1919, devido ao seu clima ameno e saudável. Sem ter sido uma ārea de colonização, a formação de núcleos de japoneses prende-se à mobilizaçāo dos antigos colonos da área de expansāo cafeeíra, atraidos pelo clima, bem como por orientação médica, S. Takaoka a indicava para a recuperação da saūde perdida em regiōes quentes e úmidas. Uma outra razão para aí se estabelecerem foram as condiçōes de poderem ser proprietärios de glebas de 4 a 5 ha, a fim de exploração da hortifrutícultura.29

KUNIYOSHI e PIRES 9 descrevem, com propriedade, esta atraçāo e crescente fixação dos japoneses nesta área em es tudo. "Na realidade, a concentração japonesa em Mogi das Cruzes, 


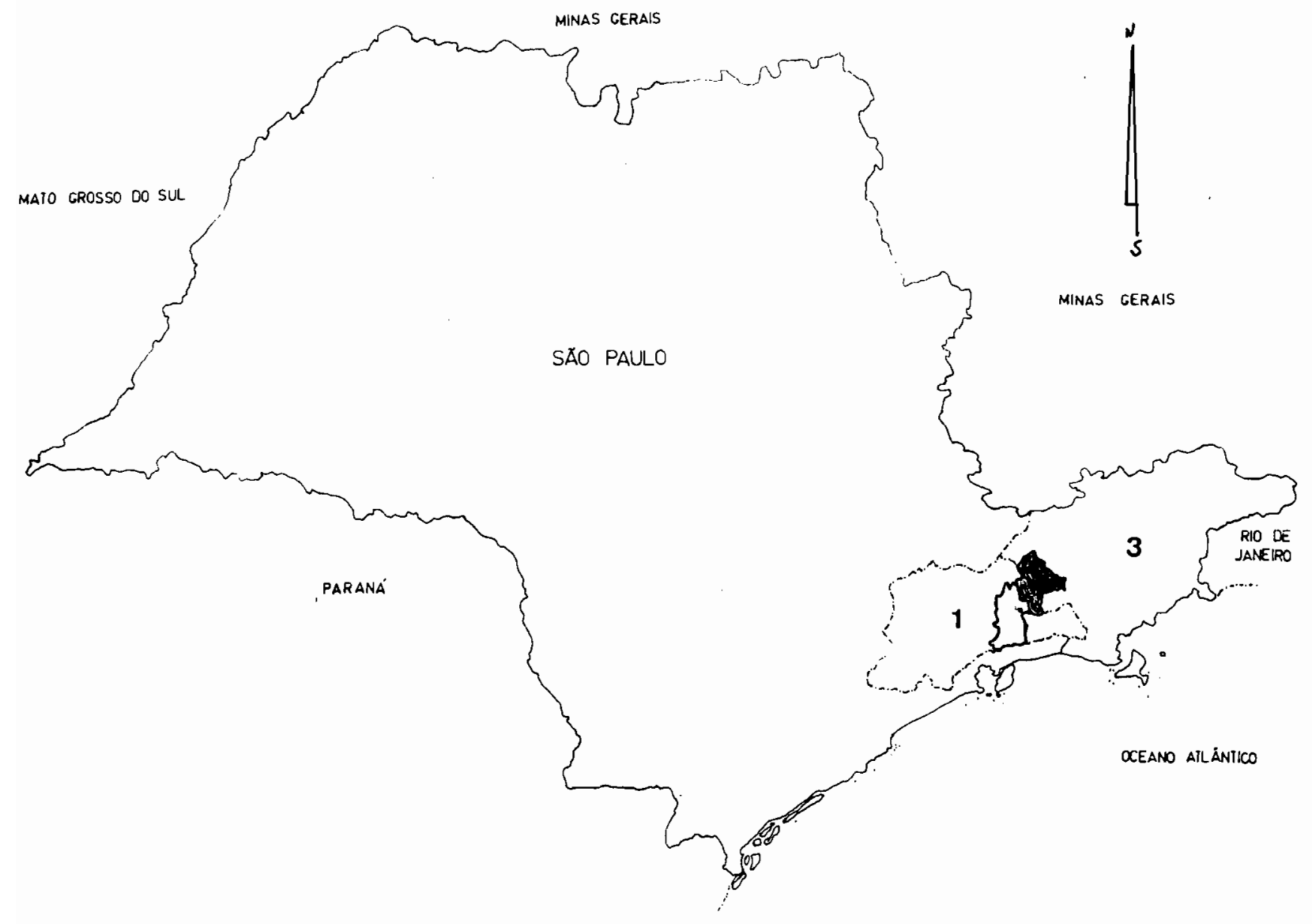

FIGURA 1 - MAPA DO ESTADO DE SATO PAULO E LOCALIZAÇAOO DA AREA EM ESTUDO: Ia. REGIAO ADMINISTRATIVA DA GRANDE SAOO PAULO, MUNICTPIOS DE MOGI DAS CRUZES E GUARAREMA; $3 a$. REGIAOO ADMINISTRATIVA DO VALE DO PARAÍBA, MUNICTPIO DE JACAREÍ 
voltada para a produçāo hortifrutigranjeira, esteve intimamente relacionada à crescente industrialização e urbanização da metrópole paulistana e dos municípios vizinhos, ao aumento da demanda de abastecimento exigida pela expansāo demogrāfica e à modificação dos hábitos alimentares dessa produção. Outro fator para o desenvolvimento dessa produção foi a melhoria das condiçōes de transporte no Vale do Paraíba, que abriu possibilidades de ligação com dois grandes mercados consumidores (São Paulo e Rio de Janeiro), assim com a formaçäo e consolidação de Cooperativas Agricolas, que apoiaram as atividades dos lavradores, por meio do fornecimento de sementes, adubos, da assistência técnica e da comercialização de seus produtos". 
7. METODOLOGIA

Para o conhecimento de häbitos alimentares de uma comunidade é necessário o registro do histórico alimentar por um período de tempo que cubra todo um ciclo alimentar e o registro das características da população e do meio ambiente em que viveu dúrante o período de anälise.

Uma vez que a população e a ārea de estudo jā foram previamente definidas, cabe dimensionar:

- a representatividade estatística da população;

- a caracterizaçāo do instrumental mais adequado ao registro e coleta das informaçōes;

- a forma de tratamento e análise dos resultados.

Com relação à representatividade da população, em função de sua dispersão geogrä́fica em três núcleos rurais, e ao pequeno número de famílias (186), optou-se por aplicar a pesquisa à totalidade da população.

Para o registro e coleta de dados, adotou-se co mo instrumental um conjunto de formulários.

A anălise dos resultados centrou-se na evolução dos häbltos alimentares nas situaçōes abaixo:

- IAG "isseis" que imigraram antes da II Guerra Mundial;

- Donikkeis̈ ou descendentes;

- IDG -"isseis" imigradosno pós-guerra.

Comparandorse os resultados, obtiveram-se os diferenciais de hábitos alimentares em trēs grupos gerados em situaçōes e momentos histórico-sociais característicos. 
7.1. Formulário

Utilizou-se como instrumental de coleta e regis tro de dados, duas modalidades de formulārios abrangendo aspec tos populacionais - alimentares e do meio ambiente, sendo que - primeiro refere-se à informes familiares, histórico alimen tar e recordatónio de vinte e quatro horas.

Os formulários referentes aos informes familiares, ao meio ambiente e à histōria familiar foram elaborados especificamente para o presente trabalho.

Com relação ao recordatório de vinte e quatro horas foi utilizado um questionário: elaborados no Departamento de Nutrição da Faculdade de Saúde Pública da Universidade de são Paulo (AnEXos 1 e 2).

Para a elaboração do formulário do meio ambiente utilizou-se a conceituaçäj³estabelecida pela Fundação do IBGE para o PNAD - Pesquisa Nacional de Amostragem por DomiciIio, 1976 (ANEXO 3).

Estes formularios foram submetidos a teste prévio, aplicados numa localidade rural, do Município de Atibaia, Estado de São Paulo, cuja atividade agrícola assemelhava - se com o local de estudo.

\subsection{Entrevistas}

A aplicaçāo dos formulārios foi executada por equipe composta por doze entrevistadores universitários. 0 per fil de entrevistador que melhor se adaptou a este estudo, foi o do estudante de Nutriçāo, com ascendência japonesa. O levantamento de dados em campo foi supervisionados por três nutri cionistas, também de origem nipōnica,que, por sua vez, tinham o 
assessoramento e a coordenaçāo de dois nutricionistas-docentes. Toda a equipe submeteu-se a treinamento prévio, visando a obtenção de dados homogēneos.

$$
\text { Quanto à tëcnica de entrevista, seguiu-se }
$$
mesma aplicada pelo Autor na elaboração da dissertação de Mestrado, 24 mantendo, assim, as condições de comparabilidade dos resultados. "Entrevistou-se concomitantemente, o chefe-de-família e a dona-de-casa e, na ausência desta, aquele era sempre auxiliado pelo membro da familia que costumeiramente preparava as refeições. Quando presente somente a dona-de-casa, procurava-se complementar as informaçōes com um outro elemento da familia, com idade superior a 15 anos. Para bem transmitir as perguntas formuladas e obter respostas confiáveis da população estudada, procedeu-se à entrevista em português e japonês"

o tempo dispendido para cada entrevista variou

de uma hora a duas horas. Cada entrevista era composta de duas partes por consecutivas, limitando-se o levantamento dos dados a duas familias por entrevistador por dia.

7.3. Critério de identificação da população pesquisada

A população em estudo constou da totalidade das famílias de origem japonesa, residentes naslocalidades.

Tomourse a familia como unidade de estudo, alijando-se, entretanto, as famílias constituídas por casal interracial, pois isto poderia interferir no comportamento do pro blema a que se propōs analisar.

Utilizou -se, para identificar os imigrantes e seus descendentes, a nomenclatura já consagrada pela colōnia japonesa: "Issei" (os japoneses vindo do Japão) e " nikkei " (os descendentes dos isseis).

Para se padronizar e referir o grau de geração a que pertencia o individuo, tomou-se como base apenas a linha 
paterna, contorme a segurr esquematızano:

Termo Sigla Condição de grau de geração

$\begin{array}{ccc}\text { Issei } & \text { I } & \text { Os nascidos no Japāo } \\ \text { Nikkei } & D^{*} & \text { Filhos de pai I e mãe I ou D } \\ & & \text { ou }\end{array}$

Filhos de pai $D$ e māe I ou $D$

* convecionou-se com sigla $D$, de descendente, em vez de $N$, de "nikkei", para fins präticos na construção de tabelas.

No que se refere à unidade de estudo, classificaram-se as familias como "issei" e descendentes ("nikkeis"), seguindo o mesmo critērio já citado, isto é, pelo grau de geraçāo a que pertencia o chefe-de-familia.

Nas áreas de estudo, todas as familias japone sas e seus descendentes foram identificados e localizados.

As trēs colōnias japonesas, incluídas no estudo, estavam bem delimitadas na zona rural e completamente isola das entre sí, cada uma pertencendo a um Município.

\subsection{Inquérito de häbitos alimentares}

$$
\text { 7.4.1. Mëtodo }
$$

Em razāo de poder contar com pessoal auxiliar para se obter informações mais extensivas sobre padrão alimen tar da população em estudo, foram empregados dois procedimentos de coleta de dados no inquérito alimentar: o método da histōria alimentar e o consumo quantificado de vinte quatro 
horas da família ${ }^{7}$. Esta decisäo permitiu atender às proposi çōesprimordiais propostas para a deteç̧ão do consumo de alimen tos usuais das três colônias japonesas, localizadas nos Municí pios de Mogi das Cruzes, Guararema e Jacareí, SP, captar a frequência com que esses alimentos são consumidos em um período anual, bem como, quantificá-los, em gramas, cobrindo uma se mana completa em cada colônia.

Para o mētodo da histöria alimentar,utilizou-se formulário com lista de alimentos e suas respectivas frequên cias de consumo (diária, semanal, mensal e eventual). Esta listagem de gēneros alimentícios foi resultante de levantamentos preliminares, obtida por meio de diferentes visitas in 10co, entrevistando em cada colônia, sua respectiva representante da Associação Feminina local.

Para se elaborar a listagem referente às verduras e frutas, empreganam-se não só a verificação in 10co, como também complementou-se a lista com dados constantes dos boletins estatísticos do ano de 1980, fornecidos pelo Entreposto Terminal de São Paulo - CEAGESP. 6 Assim feito, pôde-se conhecer a sazonalidade da oferta desses produtos agrícolas.

As variedades dos alimentos encontrados em uma primeira aproximação, conforme se apresenta no formulärio, foram estratificadas em essencialmente orientais e não-orientais, sendo que, neste ültimo grupamento, incluiram-se os alimentos comuns ao ocidente e oriente.

o método da histöria alimentar fornece uma idéia longitudinal do consumo de alimentos durante determinado perio-. do que, no presente trabalho, foi de doze meses. No entanto, apesar desse método depender de memorização, tem a vantagem de cobrir o período também de un ano. Para contornar a limitação da memória, utilizou-se, concomitante, o mëtodo de con 
sumo familiar de vinte-quatro horas. Este método consiste na indagação sobre o consumo de alimentos no dia da entrevista, pesando-se também todos os ingredientes utilizados, com equipa mentos próprios de medição. No dia subsequente, realiza-se o retorno, a fim de confirmar ou complementar as informações for necidas (coleta vertical). Por sua vez, este mëtodo sofre limi tações porque somente fornece dados sobre a alimentação de um dia da semana; procurou-se, então, cobrir o período de sete dias consecutivos, de forma simultânea, nas três localidades, para que estas informaçōes representassem as variaçōes semanais do uso de alimentos e seus respectivos preparos.

Alêm dos dados alimentares, foram incluídos outros, complementares, tais como: meio ambiente, atividade: prin cipal da família, sua composiçāo, idade, sexo, grau de instrú ção e geração, parentesco, naturalidade, ano de imigração dos isseis. Essas informaçōes objetivaram enriquecer o trabalho, , auxiliando assim, a análise da mudança dos hábitos alimentares.

7.5. Critérios adotados para a apuração de frequência de citações dos alimentos (UAR) 24

Os alimentos consumidos pela população em estudo. classificam-se em: preponderantemente orientais, preponderantemente ocidentais, incluindo, ainda, as verduras e as frutas que apresentavam sazonalidade.

Para facilitar a deteç̧āo de possíveis mudanças ocorridas nos hābitos alimentares dessa populaçāo, gruparam-se as citações da frequência de consumo dos diversos alimentos em Unidade Anual de Referēncia (UAR) ${ }^{24}$ a saber:diäria, semanal, mensal e eventual. Para tanto, utilizaram-se somente aqueles alimentos referidos no formulário de hābitos alimentares e ob- 
tidos pelo método, jâ descrito, da história alimentar, cerceando no que tange às verduras e frutas pelas razōes apresentadas de sazonalidade.

As familias estudadas, quanto ao periodo de instalaçāo no País, foram catalogadas em três tipos: famílias "isseis" que para aqui migraram antes da eclosāo de II Guerra Mundial (IAG); famillias "nikkeis", descendentes dos IAG (D) e as famílias isseis que imigraram depois da Guerra (IDG).

Para que se pudessem obter a frequència anual de mençōes dos alimentos, transformaram-se os dados em uma grandeza quantificável. Desta forma, inicialmente, fixaram se os valores numëricos correspondentes às diferentes. UAR (TABELA 1).

TABELA 1 - Valor numērico das categorias (diäria, semanal, mensal e eventual) da Unidade Anual de Referência (UAR)

UAR Proporção anual Valor numérico

Diária $\frac{365}{1}$ 365

Semanal $\frac{36}{7}$

Mensal $\frac{365}{30}$ 12

Eventual nāo permitente Valor especifico*

Somatória da frequência de cada alimento de consumo esporádi co, acima da categoria mensal, durante o ano, dividida pelo nú mero de alimentos mencionados. 
Para cada alimento, a soma de citaçōes dentro de cada UAR ( ANEXOS $4 \mathrm{~A}$ e $5 \mathrm{~A}$ ), quando já multiplicada pelo respectivo valor númerico (TABELA l) e pelo fator especifico ( $f_{e}$ )* do mesmo alimento ( $A N E X O S$ 4B e 5B) dará o consumo anual total deste alimento. Dividindo-se esta ültima cifra pelo número total de familias, ter-se-á o consumo familiar médio anual deste alimento na comunidade estudada.

Este procedimento foi desenvolvido para os grupamentos de famílias "isseis" antes da II Guerra Mundial (IAG), famílias "nikkeis" ou descendentes (D) e isseis depois da Guer ra (IDG). Isto permitiu estudar, comparativamente, a densidade de consumo dos diferentes alimentos pelos grupamentos equacionados (ANEXOS 6 e 7).

Para nortear a diferença existente no comportamento da frequência de citações anuais dos alimentos entre as familias IAG, D e IDG, recorreu-se ao teste estatístico não-pa ramētrico do sinal ${ }^{45}$, com nível de significância $\alpha=5 x^{16}$.

As consideraçōes sobre os resultados de ocorrên cia da frequência de mençōes anuais dos alimentos foram analisados, a partir de 148 da frequencia anual (equivalente a :52 dias por ano ou, pelo menos, l vez por semana).

Com referência a verduras e frutas, foram abali zadas de modo específico, por não se poder extender à frequência anual como para os outros alimentos. Assim somente se verí ficou o percentual do nümero de citaçōes, por itens das verduras e frutas, mencionadas em cada grupamento familias: IAG, D e IDG. Traçou-se deste modo, o perfil das verduras e frutas mais comuns, entre os diferentes segmentos populacionais de origem japonesa pertencentes ao estudo.

* O fator específico ( $f_{e}$ ) da categoria "diāria" será sempre hum (1). Já nas categorias "semanal", "mensal" e "eventual", os fatores específicos, nada mais são do que as médias das citacōes de cada alimento nos períodos mencionados. 


\section{APRESENTAÇAO DOS RESULTADOS}

\subsection{População em estudo}

O estudo abrangeu o universo das familias de origem japonesa, com assentamento espacial no ambiente rural da ārea escolhida.

Por meio de cadastramento, in loco,tomaram-se as familias residentes nas três colônias, localizadas em zona ru ral, pertencentes aos municípios circunvisinhos de duas Re giōes Administrativas do Estado de São Paulo: lâ Região da Grande Sāo Paulo (duas colônias) e a le Regiāo do Vale do Pạ raíba (uma colônia). As duas colónias da Região da Grande São Paulo eram: Itapeti, com 80 familias, no Municipio de Mogi das Cruzes e Sakura-Takamori, com 60 familias, no Município de Guararema. Na Regiāo do Vale do Paraíba, no Município de Jacareí, estava localizada a colonia de Parateí-do-Meio, com 46 familias, perfazendo o total de 186 familias. E, deste total de familias, $90,9 \%$ (169 familias compostas de 939 individuos) participaram do levantamento do meio ambiente.

No inquérito alimentar a participação foi de 89,88 do universo das familias cadastradas (167 familias compos tas de 931 individuos).

\subsubsection{Estrutura familiar}

A estrutura familiar das 169 familias, compostas de 939 indíviduos, está exposta em pirâmide populacional para cada tipo de estrato familiar (Figuras $2 A, 2 B, 2 C$ ) *

* IAG (33), D (38) e IDG (98). 


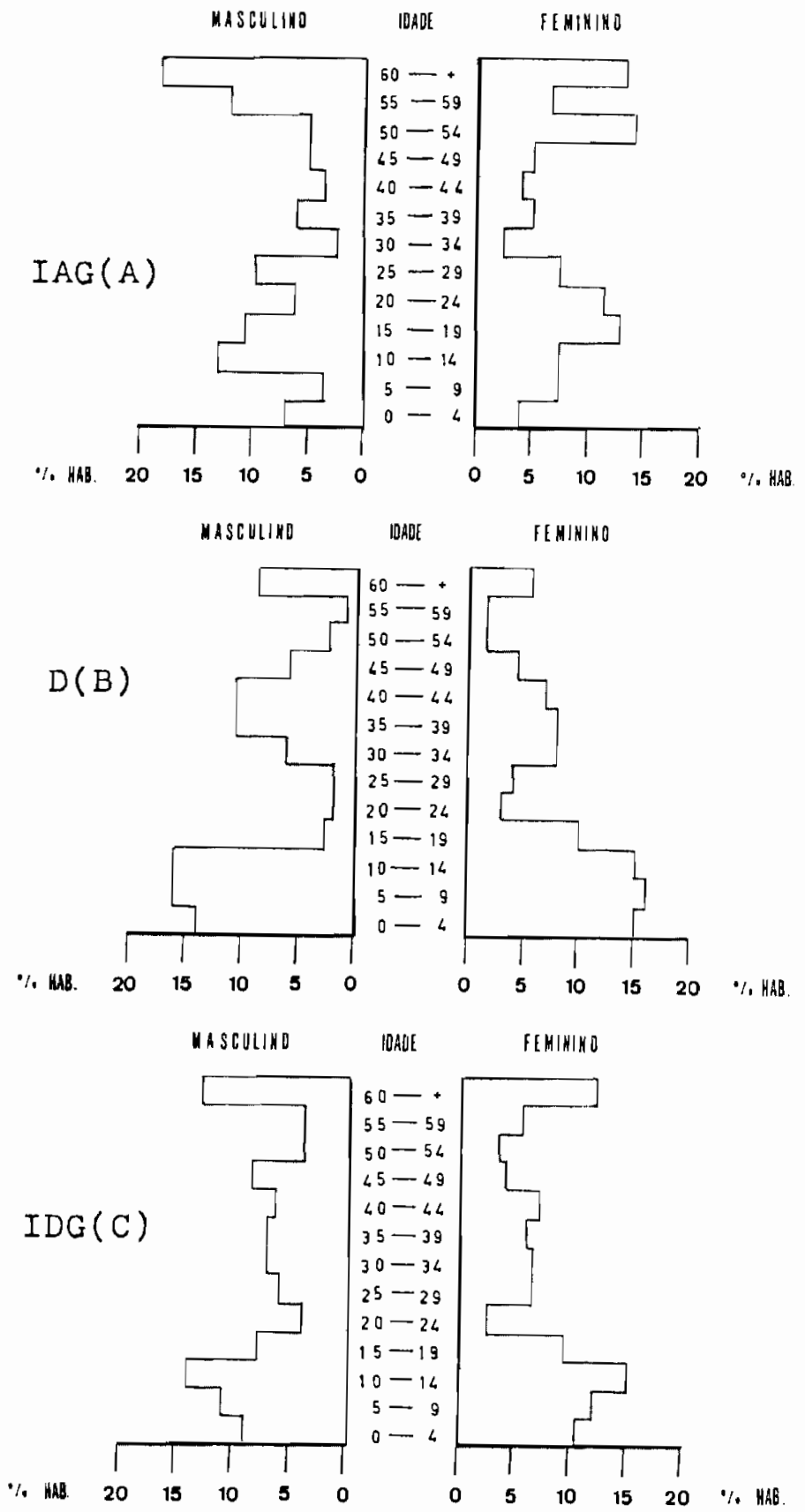

FIGURA 2 - PIRAMIDES POPULACIONAIS:IAG(A); D(B) e IDG(C) 
A idade média dos chefes-de-família, que compoẽm as famílias IAG, D e.IDG, foi de 58,4 anos, 41,2 anos e 48,0 anos, respectivamente (ANEXO 8).

8.1.3. Procedencia populacional dos chefes-de-família

Ao se examinar as informaçōes sobre a procedência dos chefes-de-família IAG e IDG, segundo a regiāo de nascí mento no arquipélago japonês, nota-se que eles são originá rios de oito Regiões do Japão, com exceçāo de una, correspon :dente à okinawa.

Observa-se nesses dois tipos de chefes-de-familia "isseis" que os da regiāo meridional do País têm maior re presentatividade, ärea esta tradicional pela saída de migran tes (Figuras 3A e 3B).

Quanto aos chefes-de-fanilia descendentes, ver $\underline{\mathbf{i}}$ fica-se grande variabilidade entre os locais de nascimento do interior do Estado de São Paulo (Figura 4).

8.1.4. Escolaridade dos chefes-de-familia

Sobre a escolaridade dos chefes-de-familias evi denciou-se que $73,1 \%$ deles tinham $1^{\circ} \mathrm{Grau}, 25,7 \%, 2^{\circ}$ Grau e so mente 1,28 possuiam Grau Superior. (ANEXO 9).

8.1.5. Anos de residência dos chefes-de-familias

Indagando-se sobre o tempo de residência dos chefes-de-familia IAG, De IDG, na ärea em estudo, verificouse que havia, nos três grupmentos familiares, uma fração dos que residiam na regiāo, antes do assentamento das colónias con sideradas. 0 contingente maior $(52,7 \%)$ foi o dos chefes-de-fami- 


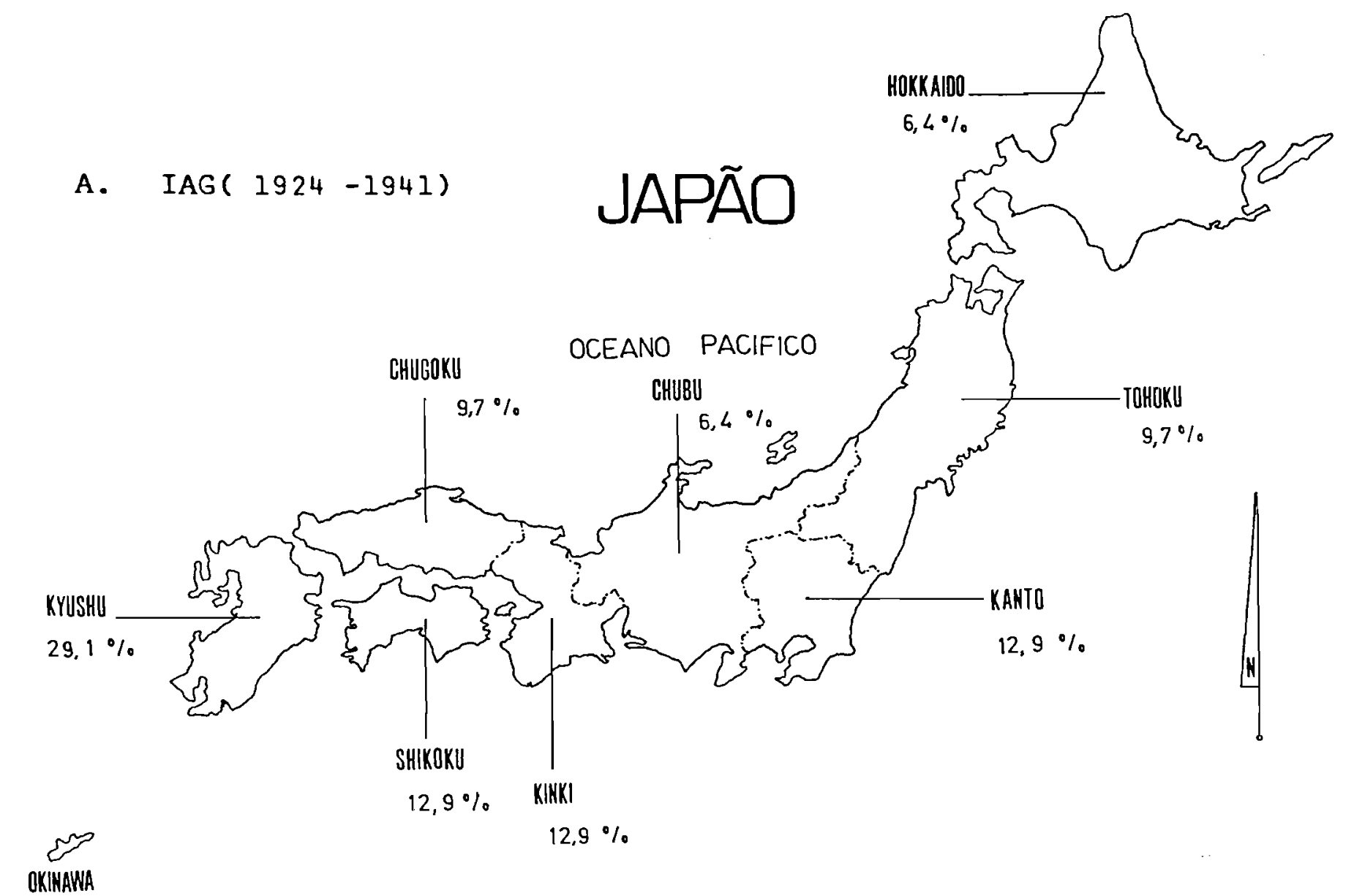

0,0

FIGURA 3A- DISTRIBUIÇÃO DA PROCEDENCIA DOS CHEFES-DE-FAMILIA 


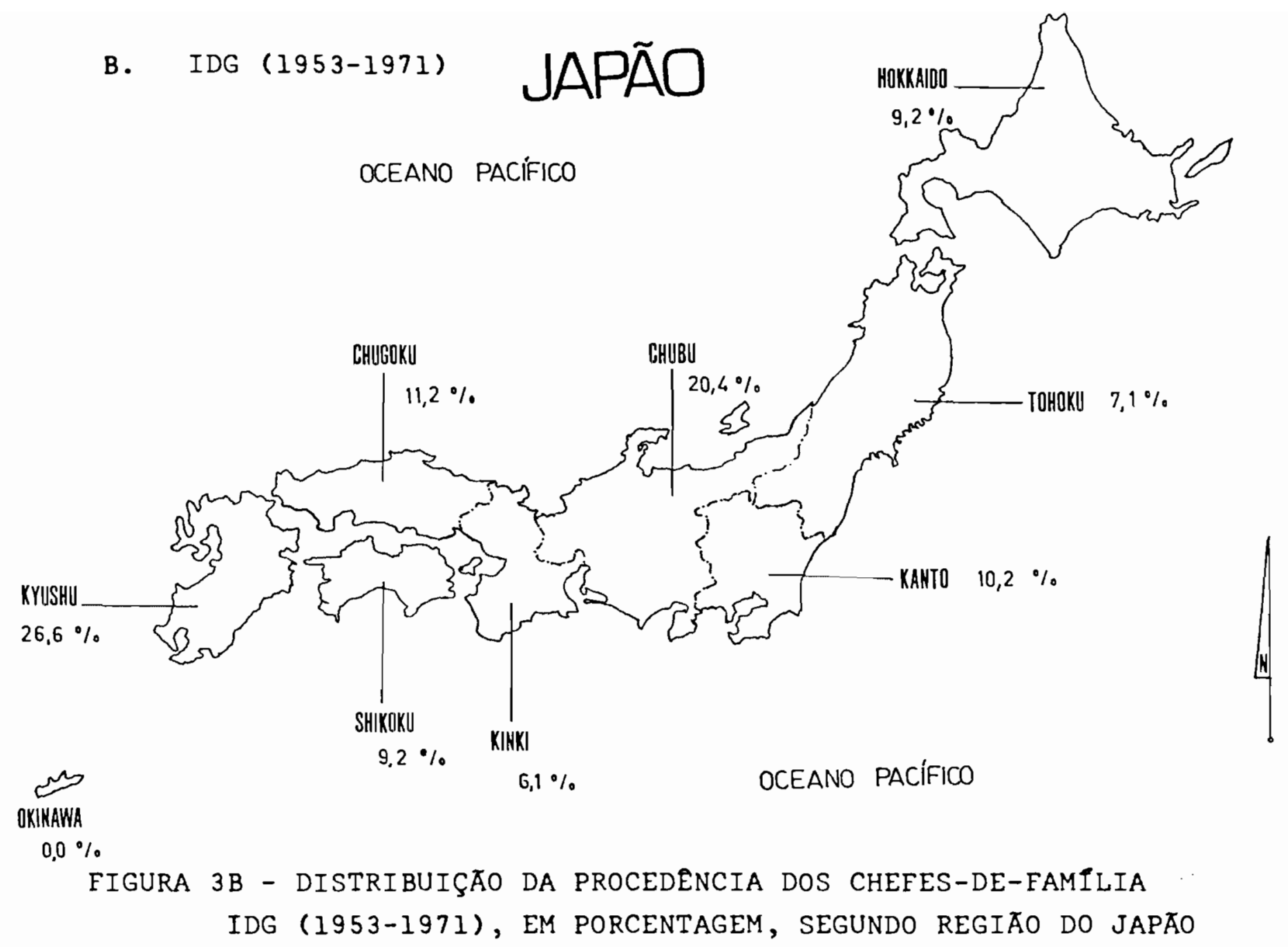




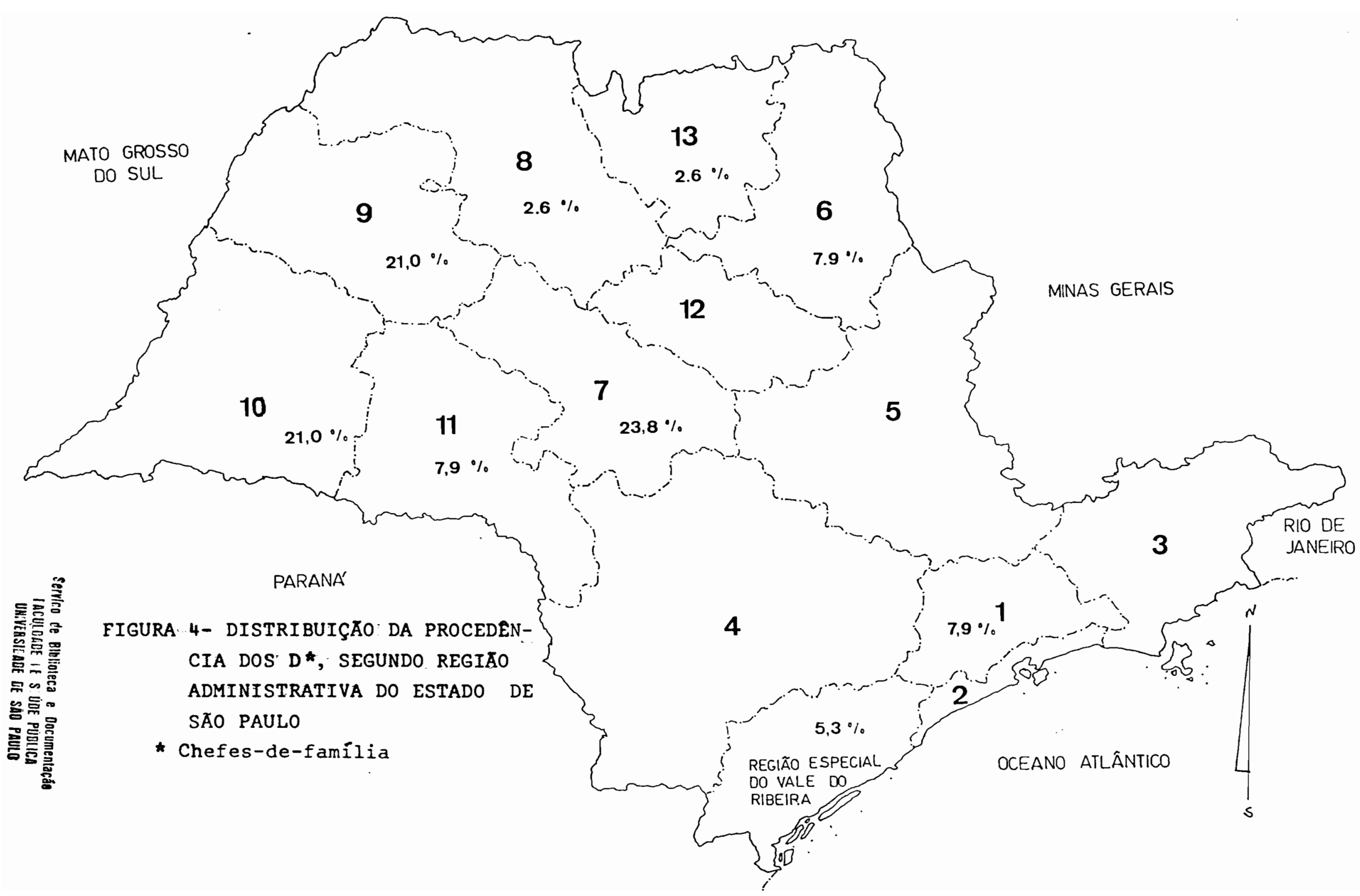


lia $D$, que moravam hā mais de 20 anos na localidade, seguidos por IDG e IAG, respectivamente, com percentual inferior a $20 \%$ (ANEXO 10).

8.2. Caracteristicas do meio ambiente da ārea de estudo

A área total ocupada pelas três colónias (Itapeti, Sakura-Takamori e Paratei-do-Meio) é de $875 a^{\star}$ e, destes, cerca de 568 são destinados à produção agrícola.

o tamanho das propriedades apresentou grande amplitude de variaçōes ( 1 a 30 a); no entanto, 55,48 do to tal das poopriedades correspondem ao tamanho de 2 a 5 a (ANEXo 11).

Kuniyoshi e PIRES ${ }^{29}$, ao historiar a instala ção de japoneses numa área próxima à colônia Itapetí, na déca da de 30 , mencionaram que as glebas destas áreas eram de 4 a 5 ha , o que vem validar as informaçōes obtidas como sendo o comum na região.

Basicamente, as colônias produziam verduras, frutas e flores, dedicando-se a essas culturas $84,1 \%$ das fami lias. O cultivo das flores é atividade mais recente, visando a diversificação da exploração da terra. Também verificou-se que a avicultura é uma das atividades agrícola, acoplada à tradicional hortifruticultura (ANEXO 12).

Em relação à situação de posse-da-terra, os dados indicaram que 85,28 eram proprietários na condição de totalmente paga (ANEXO 13).

As 169 familias estudadas, compostas por 939 pessoas, equivaleu à média de 5,55 pessoas/familia. No Brasil, 
em 1970, as familias eram compestas, em média, na área ruxal. de 5,3 elementos ${ }^{13}$, bem próxima à cncontrada na regiāo.

Quanto às condições de habitação das familias estudadas, estas aproximan-se muito da conceituaçāo de "ade quada", segundo o conceito IBGE ${ }^{12}$ (ĀNEXO tão abaixo esquematizados:

CONDIÇOES DE HABITAÇKO DAS 169 FAMILIAS EM ESTUDO

Itens Resultados em $\%$

Material de construção

durāvel

$89,2 \%$ (A.YEXO 14)

Densidade domiciliar

(1 pessoa/cómódo)

1,2 pessoas/cômodo (ANEXO 15)

Abastecimento d'àgua 100,09 (ANEXO 16)

Instalação sanitária

$100,0 \%$ (ANEXO 17)

Instalação elétrica

$100,0 \%$

* A população toda é servida por rede de eletrificação rural.

8.3. Inquérito a 1 imentar

8.3.1. Análise dos dados de hábitos alimentares

A lista de alimentos de origem preponderante mente oriental, preponderantemente ocidental, alên das verduras e frutas sazonais, encontra-se nas TABELAS 2 e 3 . A lista gem não é exaustiva; limita-se somente àqueles alimentos cita dos, pelos entrevistados, como de uso habitual, eliminando-se aqueles que não se enquadraram na categoria de "eventual", pela baixa menção no período anual. 
TABELA 2- Especificação dos alimentos pertencentes aos grupamentos alimentares: preponderantemente orientais(p.orientais) e preponderantemente ocidentais(p.ocidentais

45 alimentos p. orientais*

\begin{tabular}{ll} 
Ague & Mesashi \\
ajinomoto & Mirim \\
arroz & Misso \\
azuki & Motti \\
Cará & Natto \\
Cebolinha & Nori \\
Chá oriental & Okara \\
Chá verde & Óleo de gergelim \\
Curry & Peixe-conserva \\
Dashico & Peixe fresco \\
Fukudinzuke & Sake \\
Gengibre & Sembei \\
Gergelim & Shoyu \\
Hondashi & Soja \\
Inhame & Sunomoto \\
Kamaboco & Tikua \\
Kampio & Tofu \\
Kinaco & Tsukudani \\
Kombu & Tsuquemono \\
Konhaku & Umeboshi \\
Leite de soja & Wakame \\
Mandju & Yacult \\
Menlui & Vide glossário -ANEXo I8. \\
\hline
\end{tabular}

55 alimentos p. ocidentais

Açúcar refinado

Açúcar outros*

Aguardente

Alho

Amendoim
Azeite

Bebidas alcoólicas outras

Banha

Batata-doce

Bațata-inglesa 
continuação...

55 alimentos $p$. ocidentais

\begin{tabular}{ll} 
Café & Leite condensado \\
Chá mate & Leite fresco \\
Chá preto & Leite em pó \\
Caldo Knor & Limão \\
Carne de aves & Linguiça \\
Carne bovina & Macarrão \\
Carne sulna & Maionese \\
Carne seca & Maizena \\
Cebola & Mandioca \\
Cerveja & Mandioquinha \\
Chocolate & Margarina \\
Condimentos outros*** & Manteiga \\
Crème de leite & Massa de tomate \\
Embutido outros*** & Mel \\
Ervilha & Óleo \\
Farı́nha de mandıca & Ovo \\
Farınha de trigo & Pão \\
Feijão & Pimenta \\
Fłgado & Queljo \\
Fubá & Refrigerante \\
Iogurte & Salsicha \\
Leguminosa-outras**** & Suco de frutas \\
& Vinagre \\
\hline &
\end{tabular}

* Açúcar -outros(cristal, mascavo, glauçúcar)

* Bebidas alcoblicas-outras (wisky,vinho)

* * Condimentos outros (orégano,salsa,hortelã)

*** Embut1do-outros (presunto, salame,mortadela, presuntada)

**** Leguminosa-outras(grão de bico,lentilha). 
TABELA 3 - Especificação dos alimentos pertencentes aos grupamentos alimentares: verduras e frutas sazonais.

\begin{tabular}{|c|c|c|}
\hline Abóbora & Rabanete & Abacate \\
\hline Abobrinha & Repolho & Abacaxi \\
\hline Acelga & Salsāo & Banana \\
\hline Agrião & Samambaia (broto) * & Caqui \\
\hline Alface & Tomate & Goiaba \\
\hline Bambü (broto) & Vagem & Laranja \\
\hline Bardana* & & $\operatorname{Maçā~}$ \\
\hline Beringela & & Mamão \\
\hline Beterraba & & Manga \\
\hline Brócoli & & Maracujä \\
\hline Cenoura & & Melancia \\
\hline Chicorria & & Melão \\
\hline Chuchu & & Morango \\
\hline Cogumelo & & Néspera \\
\hline Couve & & Pera \\
\hline Couve-flor & & Pinha \\
\hline Espinafre & & Uva \\
\hline \multicolumn{3}{|l|}{ Ervilha. (vagem) } \\
\hline \multicolumn{3}{|l|}{ Giló } \\
\hline \multicolumn{3}{|l|}{ Lotus (raiz) } \\
\hline \multicolumn{3}{|l|}{ Milho verde } \\
\hline \multicolumn{3}{|l|}{ Moyashi } \\
\hline \multicolumn{3}{|l|}{ Nabo } \\
\hline \multicolumn{3}{|l|}{ Nirā* } \\
\hline \multicolumn{3}{|l|}{ Pepino } \\
\hline \multicolumn{3}{|l|}{ Pimentão } \\
\hline Quiabo & & \\
\hline
\end{tabular}

* Vide Glossário- ANEXO 18. 
A bem da clareza, sobre as possíveis diferenças existentes entre o consumo anual desses alimentos pelas familias IAG, D e IDG, submeteu-se, como foi mencionado, os resul tados ao tratamento estatístico nāo-paramétrico, teste de Sinal, com nível de significância $\chi=58.16$

Pela comparação pareada dos três segmentos famí liares verifica-se que houve diferença significativa de menções em cinco grupamentos de alimentos, dentre os seis considerados (TABELA 4).

- Há diferença significativa no consumo dos ali mentos preponderantemente orientais, conforme se trata de familias IAG ou de familias $D$ ou de familias IDG, independentemente de viverem na mesma área. Observou-se que os descendentes (D), significativamente, consomem menos alimentos orientais do que os ascendentes "isseis" antes da Guerra.

- Hä diferença significativa no consumo de alimentos preponderantemente orientais entre as familias IAG e IDG. Assim, as familias IDG consomem mais alimentos preponderantemente orientais do que as IAG.

- Há diferença significativa do consumo de alimentos preponderantemente orientais entre as familias IDG e D. Naturalmente, as famílias IDG consomem mais alimentos orientais do que as $D$.

- Hä diferença significativa, também, no consumo de alimentos preponderantemente ocidentais, conforme se tra te de familias IAG ou D. Assim,as familias $D$ consomem mais ali mentos ocidentais do que as famílias IAG.

- Há diferença significativa no consumo de alimentos preponderantemente ocidentais entre as familias IDG e D. Como é de se prever, as familias descendentes consomem sig nificativamente mais os alimentos ocidentais do que as fami lias IDG. 
TABELA- 4 - Resultado da aplicação do teste de sinal, $\alpha=58^{16}$, em cada alimento: preponderantemente orientais ( $\mathrm{p}$. orientais) e preponderantemente ocidentais (p. ocidentais), das famílias IAG, D e IDG.

\begin{tabular}{|c|c|c|c|c|}
\hline \multirow[t]{3}{*}{ Alimentos } & Grupamento familiar & $\begin{array}{l}\text { (A) } \\
\text { Relação de sinais do grupo } \\
\text { (a) em relaçāo ao grupo (b) }\end{array}$ & $\begin{array}{l}\text { Valor de } \\
\text { nivel de }\end{array}$ & Interpretação** \\
\hline & & Negativo (-) & cância & \\
\hline & & & $\alpha=58 \%$ & \\
\hline
\end{tabular}

\begin{tabular}{|c|c|c|c|c|c|c|c|c|}
\hline & (a) & Versus & \multicolumn{2}{|c|}{ (b) } & \multirow[b]{2}{*}{33} & \multirow[b]{2}{*}{12} & \multirow[b]{2}{*}{15} & \multirow[b]{2}{*}{ significativo } \\
\hline \multirow{3}{*}{ orientais } & IAG & $\mathrm{X}$ & $\mathrm{D}$ & (1) & & & & \\
\hline & IAG & $\mathrm{X}$ & IDG & (2) & 14 & 30 & 15 & significativo \\
\hline & IDG & $\mathrm{x}$ & $\mathrm{D}$ & (3) & 11 & 34 & 15 & significativo \\
\hline \multirow{3}{*}{ P. ocidentais } & IAG & $\mathrm{x}$ & $D$ & (4) & 17 & 37 & 19 & significativo \\
\hline & IAG & $\mathrm{X}$ & IDG & (5) & 30 & 25 & 19 & $\tilde{\mathrm{n}}$ significativo \\
\hline & $I \cdot G$ & $x$ & $\mathrm{D}$ & (6) & 19 & 36 & 19 & significativo \\
\hline
\end{tabular}

$\begin{aligned} \text { Fonte: } & \text { TABELAS: } 5(1) ; \quad 7(2) ; \quad 9(3) ; 11(4) ;: 13(5) ; \quad 15(6) \\ * \text { Usado como nivel de significancia } & \text { significativo }<\text { A } \\ & \text { Não significativo } \alpha>A\end{aligned}$


8.3.2. Consumo de alimentos preponderantemente orientais

Pela análise da TABELA 5 verifica-se que $73,3 \%$ dos alimentos preponderantemente orientais foram mais consumidos pelas familias IAG do que pelos seus descendentes. Nota -se que os sete primeiros alimentos, alinhados em ordem de gran deza das mençōes de frequência anual pelos IAG também o foram pelos D (arroz, ajinomoto, shoyu, cebolinha, misso, tsuquemono e dashico). Constatou-se que dentre esses alimentos, os mais mencionados pelos grupos de ambas as famílias, referiam-se aos ingredientes de preparó japonês tradicional (FIGURA 5).

Expressando esses resultados em termos percentu ais poder-se-à ter idéia mais clara do grau de abandono do hábito de consumir alimentos orientais entre as famílias $D$ (TABELA 6).

Ao se apurarem os dados das famílias "isseis", segundo a época que inigraram, antes da II Guerra Mundial e de pois da Guerra (TABELA 7) observou-se que os gēneros alimentícios orientais, mais citados pelos dois tipos de familias "isseis", foram os primeiros seis itens a seguir: arroz, ajing moto, shoyu, cebolinha, misso e tsuquemono. O que mais chana a atenção é a semelhança com os resultados anteriores, entre IAG e $D$, com exceção do dashico, que os IDG mencionam muito menos vezes. Na verdade, este produto alimentício, básico para o pre paro do caldo do peixe, foi substituido, pelos IDG, por um ou tro industrializado e instantàneo, o hondashi. o grupo familiar IDG diferencia-se do IAG quanto às citações de frequência do uso dos condimentos misso, hondashi e cebolinha. Os dados sugerem que, ainda, há uma certa tendência na conservação desse hábito nas familias IDG, como atualmente no Japão, alimen tos estes, com características de preparo. rápido, que oferecem maior facilidade de uso, enquanto que entre os IAG e D,pro 
vavelmente, face às mençōes sobre os condimentos, os tipos de preparaçōes sejam mais trabalhosos.

A FIGURA 5 apresenta visualmente estas diferen ças, bem como a TABELA 8, expressas em termos percentuais das diferenças entre IAG e IDG.

Quanto ao consumo dos alimentos preponderantemente orientais, entre os IDG e D (TABELA 3), verifica-se, com raras exceções, que famílias IDG demonstram superioridade de mençōes em relação à frequência anual. Entretanto, os seis primeiros itens de alimentos orientais foram: arroz, ajinomoto, shoyu, misso, cebolinha e tsuquemono.

Por mais estranho que pareça, os $D$ apresentam preferência superior em relação aos IDG em dashico. Este alimento, tambēm, foi citado pelos IAG mais do que pelos IDG.

Expressando-se esses resultados, em termos

percentuais, TABELA 10, poder-se ter idéia mais clara do grau de abandono do hábito de consumir alimentos preponderantemente orientais entre as famílias IDG e D.

Os alimentos preponderantemente orientais mencionados no mínimo 1 vez por semana ao ano,dentre os trés seguimentos familiares, (IAG, D e IDG) foram: arroz, ajinomoto, shoyu, cebolinha, misso, tsuquemono, chä verde, peixe fresco, gengibre, fukudinzuke, memlui, umeboshi e sembei.

A representaçāo gräfica (FIGURA 5) visualiza

que entre os $D$, realmente há retração quanto ao consumo de alimentos orientais, embora a maioria esteja presentes pelo menos 148 ao ano (equivale a 1 vez ao ano), tal como, IAG e IDG. Portanto os "nikkeis" que descendem dos "isseis" antes da Guerra, representam o retrato atenuado de seus pais, que lhes transmitiram seu padrāo alimentar japonês tradicional. 
TABELA 5 - Diferenças absolutas de citaçöes anuais entre famílias isseis antes da guerra (IAG) e descendentes (D), segundo ordem de grandeza dos alimentos preponderadamente orientais (p. orientais)

Alimentos p. Frequência de citaçōes orientais anuais/familia

$\operatorname{IAG}(\mathrm{a})$

n

$D(b)$

n

362,2

351,4

285,3

183,4

222,1

192,5

108,3

57,4

92,1

53,3

86,0

46,6

66,4

46,6

64,8

58,9

53,7

53,6

49,2

36,8

35,2

28,3

20,1

17,5

16,1

16,0

15,7

13,4

12,9

12,2 de Diferença em $n$ absc luto entre familias IAG e $D$.

$(a-b)$

$\mathrm{n}$

\begin{tabular}{|c|c|}
\hline+ & 2,8 \\
\hline - & 2,2 \\
\hline+ & 58,1 \\
\hline+ & 61,8 \\
\hline+ & 18,5 \\
\hline+ & 34,2 \\
\hline+ & 1,8 \\
\hline+ & 44,1 \\
\hline+ & 6,6 \\
\hline+ & 41,1 \\
\hline+ & 8,2 \\
\hline+ & 43,2 \\
\hline+ & 12,4 \\
\hline+ & 18,2 \\
\hline+ & 58,9 \\
\hline+ & 2,2 \\
\hline - & 0,3 \\
\hline+ & 23,3 \\
\hline+ & 21,5 \\
\hline . & 17,8 \\
\hline+ & 5,5 \\
\hline+ & 4,3 \\
\hline+ & 0,5 \\
\hline+ & 7,5 \\
\hline+ & 2,3 \\
\hline _ & 0,9 \\
\hline 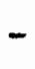 & 6,5 \\
\hline+ & 4,0 \\
\hline+ & 9,8 \\
\hline
\end{tabular}


Continuação ... TAB.5

Alimentos p. Frequência de citações orientais anuais/familia

\section{$\operatorname{IAG}(a)$}

n

Motti

Nori

Yacult

Kampio

Natto

Wakane

Azuki

Kombu

Soja

Sunomoto *

бleo gergelim *

Peixe conserva

Kinaco*

Sake

Leite de soja

Okara
$D(b)$

n

13,5

6,1

35,9

9,7

9,7

6,3

9,0

5,0

6,0

3,0

0,2

3,7

0,3

8,2

1,8

2,1
Diferença em n abso luto entre famílias IAG e D.

$(a-b)$

ก

$-\quad 1,8$

$+\quad 5,4$

- 24,9

$+\quad 0,3$

$-\quad 0,3$

$+\quad 2,9$

$+\quad 0,4$

$+\quad 2,7$

$+\quad 1,2$

$+3,4$

$+\quad 5,6$

$+\quad 0,7$

$+\quad 0,6$

- 8,0

- 1,8

- 2,1

* -Condimentos 
TABELA 6 - Diferenças percentuais de citações anuais de alimentos orientais, considerando os IAG como 1008 , segundo ordem de grandeza dos $D$

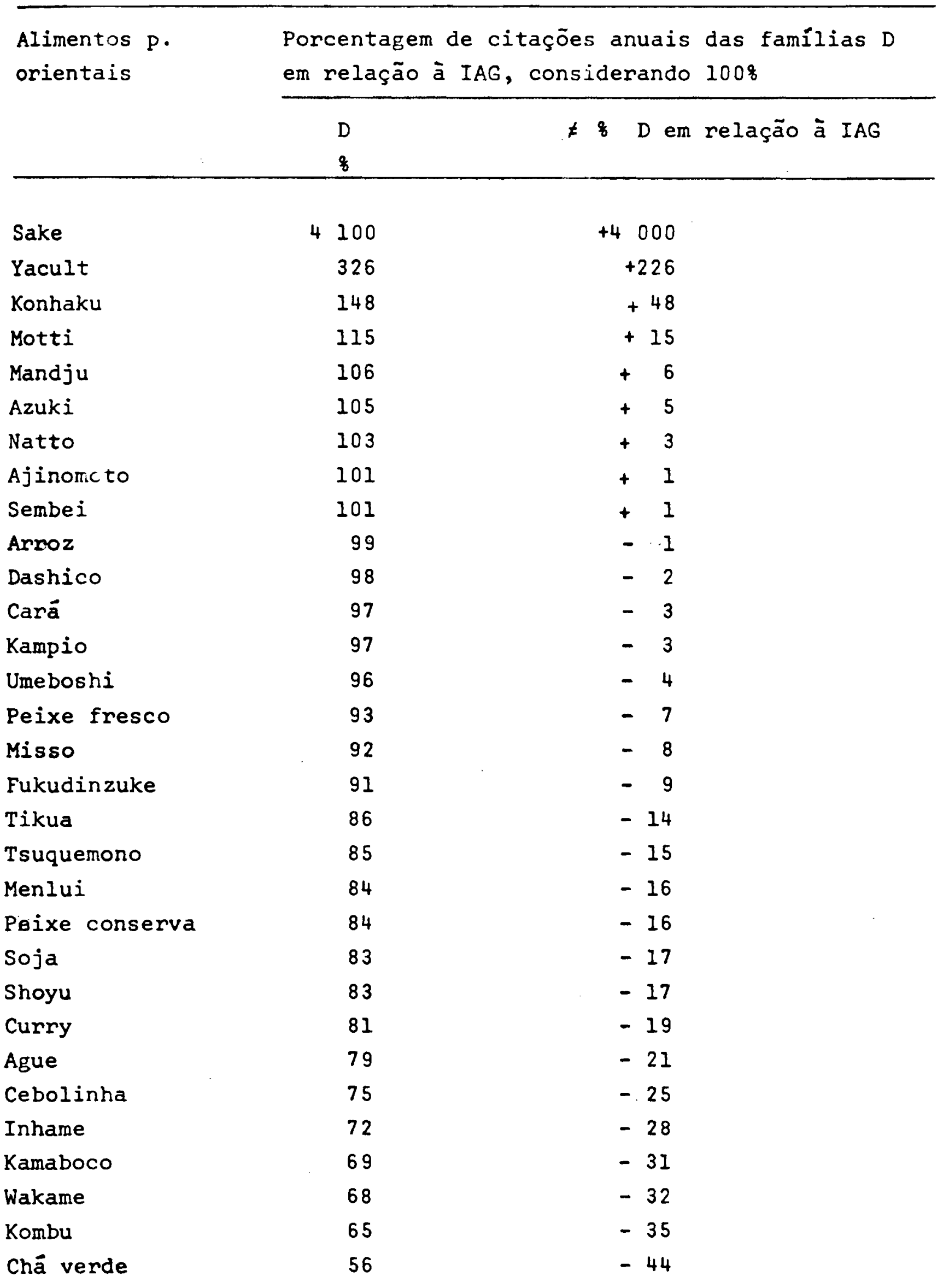


Continuação ... TAB. 6

Alimentos $\mathrm{p}$.

Porcentagem de citações anuais das famillias D

orientais em relação à IAG, considerando $100 \%$

$\mathrm{D} \quad \neq$ D em relação à IAG

\&

Gengibre

Mesashi

Nori

Tofu

Hondashi

Tsukudani

Sunomoto

Gergelim

Oleo gergelim

Kinaco

Mirim

Chá oriental

Leite de soja

okara
$-44$

$-47$

-47
$-\quad 47$

-47
$-\quad 48$

-48
$-\quad 47$

- 51

$-53$

$-58$

$-66$

$-67$

$-80$

20

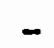


TABELAt.7 - Diferenças absolutas de citaçōes dos alimentos preponde-

Alimentos p. freqüência de citaçōes orien:ais anuais/familia

$$
\operatorname{IAG}(\mathrm{a})
$$

n

$\operatorname{IDG}(\mathrm{b})$

n

365,0

348,9

339.6

267,4

292.6

266,0

35,6

212,9

117,2

85,7

73,6

115,1

87,7

58,3

52,7

103,9

57,0

106,2

51.2

44,9

30,2

71,9

26,0

2,9

6,6

26,5

34,8

5,6
Tsukud ani

Ague

Cará

Mesash:

Tikua

Mgand

Konhak:1

Ramaboro
15,7

13,4

12,9
16,1

16,0 radamente orientais ( $p$. orientais) entre familias isseis antes da guerra (IAG) e isseis depois da Guerra (IDG), se gundo ordem de grandeza
Diferença em $n$ abso luto entre familias IAG e D.

$$
(a-b)
$$

n $+\quad 0.3$

$+3,8$

- 22,2

$-52.0$

$-39,3$

$+74,5$

$-111: 4$

$-18,5$

$+8.7$

$+20,6$

$-25,3$

$-8,9$

$+6,5$

$+6.2$

$-50,2$

$-3,4$

- 57,0

$-14,4$

$-\quad 9.7$

- 1,9

$-51,8$

$\begin{array}{r}-8,5 \\ \hline\end{array}$

$+13,2$

+13
$+\quad 9.4$

$-10,8$

$-21.4$

$+\quad 7,3$ 
Continuação. .. TAB. 7

Alimentoș p. frequência de citações orientais anuais/familia

$$
\operatorname{IAG}(\mathrm{a})
$$

n

$I D G(b)$

n
Diferença em $n$ absoluto entre famílias IAG e D.

$$
(a-b)
$$

\begin{tabular}{|c|c|c|c|}
\hline Mirim ${ }^{*}$ & 12,2 & 23,1 & $-\quad 10,9$ \\
\hline Motti & 11,7 & 14,9 & $-\quad 3,2$ \\
\hline Nori & 11,5 & 4,9 & 6,6 \\
\hline Yacult & 11,0 & 24,7 & 13,7 \\
\hline Kampio & 10,0 & 7,3 & 2,7 \\
\hline Natto & 9,4 & 24,5 & 15,1 \\
\hline Wakame & 9,2 & 4,2 & 5,0 \\
\hline Azuki & 8,6 & 10,9 & 2,3 \\
\hline Kombu & 7,7 & 4,6 & 3,1 \\
\hline Soja & 7,2 & 12,1 & 4,9 \\
\hline Sunomoto $*$ & 6,4 & 11,3 & 4,9 \\
\hline Oleo gergelim * & 5,8 & 8,9 & 3,1 \\
\hline Peixe-conserva & 4,4 & 6,2 & 1,8 \\
\hline Kinaco* & 0,9 & 1,3 & 0,4 \\
\hline Sake & 0,2 & 21,7 & $-\quad 21,5$ \\
\hline Leite de soja & 0 & 8,5 & 8,5 \\
\hline Okara & 0 & 2,9 & 2,9 \\
\hline
\end{tabular}

n

* Condimentos 
TABELA 8. - Diferenças percentuais de citaçōes anuais de alimentos preponderadamente orientais ( $\mathrm{p}$. orientais), toman do as menções das famílias IAG como $100 \%$, segundo ordem de grandeza dos IDG

\begin{tabular}{|c|c|c|c|}
\hline \multirow[t]{2}{*}{$\begin{array}{l}\text { Alimentos } p \text {. } \\
\text { orientais. }\end{array}$} & \multicolumn{3}{|c|}{$\begin{array}{l}\text { Porcentagem de citaçōes das famílias IDG em } \\
\text { lação à IAG considerando } 100 \%\end{array}$} \\
\hline & $\begin{array}{l}\text { IDG } \\
\&\end{array}$ & $\neq \&$ IDG em & m relação à IAG \\
\hline Sake & 10,850 & +10 & 750 \\
\hline Ague & 358 & + & 258 \\
\hline Natto & 261 & + & 161 \\
\hline Konhaku & 260 & + & 160 \\
\hline Yacult & 224 & + & 124 \\
\hline Tofu & 216 & + & 116 \\
\hline Chà verde & 210 & + & 110 \\
\hline Umeboshi & 193 & + & 93 \\
\hline Mirim & 289 & + & 89 \\
\hline Sunomoto & 177 & + & 77 \\
\hline Mandju & 169 & + & 69 \\
\hline Soja & 168 & + & 68 \\
\hline Oleo gergelim & 153 & + & 53 \\
\hline Cará & 149 & + & 49 \\
\hline Kinaco & 144 & + & 44 \\
\hline Peixe conserva & 141 & + & 41 \\
\hline Gergelim & 139 & + & 39 \\
\hline Tsukudani & 128 & + & 28 \\
\hline Hondashi & 128 & + & 28 \\
\hline Motti & 127 & + & 27 \\
\hline Azuki. & 127 & + & 27 \\
\hline Misso & 122 & + & 22 \\
\hline Peixe fresco & 119 & + & 19 \\
\hline Tsuquemono & 117 & + & 17 \\
\hline Menlui & 111 & + & 11 \\
\hline Cebolinha & 109 & + & 9 \\
\hline Curry & 107 & + & 7 \\
\hline Sembei & 106 & + & 6 \\
\hline Arroz & 100 & & 0 \\
\hline
\end{tabular}


Continuação... TAB. 8

Alimentos p. Porcentagem de citaçōes das famílias Ing em reorientais lação à IAG considerando $100 \%$

8

\# : IDG em relação à IAG

$\begin{array}{lrr}\text { Ajinomoto } & 100 & 0 \\ \text { Shoyu } & 99 & -1 \\ \text { Gengibre } & 91 & -9 \\ \text { Inhame } & 90 & -10 \\ \text { Chä oriental } & 89 & -11 \\ \text { Fukudinzuke } & 78 & -22 \\ \text { Kampio } & 73 & -27 \\ \text { Kombu } & 60 & -40 \\ \text { Nori } & 43 & -57 \\ \text { Kamaboco } & 43 & -57 \\ \text { Tikua } & 41 & -59 \\ \text { Dashico } & 32 & -68 \\ \text { Mesashi } & 18 & -82 \\ \text { Wakame } & 5 & -95 \\ \text { Leite de soja } & - & - \\ \text { Okara } & - & \end{array}$


TABELA 9 - Diferenças absolutas de citaçōes anuais entr famílias isseis depois da guerra (IDG) e descendentes (D), se gundo ordem de grandeza dos alimentos prepoiceradamen te orientais ( $p$. orientais)

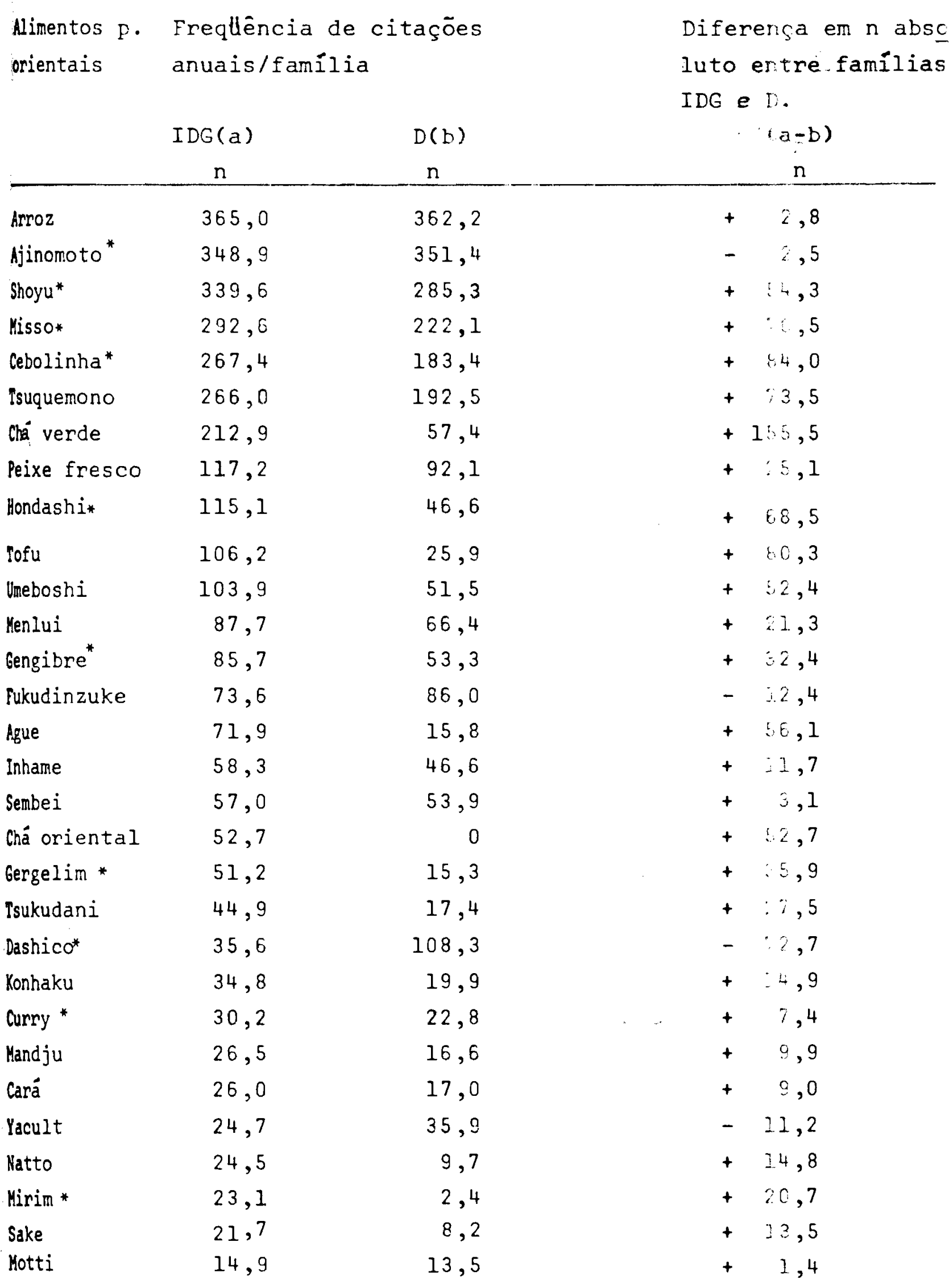


Continuą̧ão... TAB.9

Alimento p. Freqüēncia de citações

orientais anuais/família

$\operatorname{IDG}(\mathrm{a}) \quad D(\mathrm{~b})$

$\mathrm{n}$

$\mathrm{n}$

$\begin{array}{ll}\text { Soja } & 12,1 \\ \text { Sunomoto } & 11,3 \\ \text { Azuki } & 10,9\end{array}$

oleo gergelim * 8,9

Leite de soja 8,5

Kampio

7,3

likua

6,6

Peixe conserve 6,2

Kamaboco

5,6

Nori

4,9

kombu

Nakame

Mesashi

Okara

kinaco *
6,0

3,0

9,0

0,2

1,8

9,7

13,7

3,7

8,9

6,1

5,0

6,3

8,6

2,1

0,3
Diferenca em $\mathrm{n}$ abso luto entre famílias

IDG e D.

$(a-b)$

.

$+6,1$

$+8,3$

$+\quad 1,9$

$+8,7$

$+6,7$

$-2,4$

$-\quad 7,1$

$+\quad 2,5$

$-\quad 3,3$

- 1,2

- 0,4

$-\quad 2,1$

$-\quad 5,7$

$+\quad 0,8$

$+\quad 1,0$

*- Condimentos 
TABELA 10 - Diferenças percentuais de citações anuais de alimentos orientais, considerando OS IDG como 100\%, serundo or dem de grandeza dos $D$ $\begin{array}{ll}\text { Alimentos } p . & \text { Porcentagem de citaçōes das familias } D \text { en relação } \\ \text { orientais } & \text { à IDG considerando } 100 \%\end{array}$

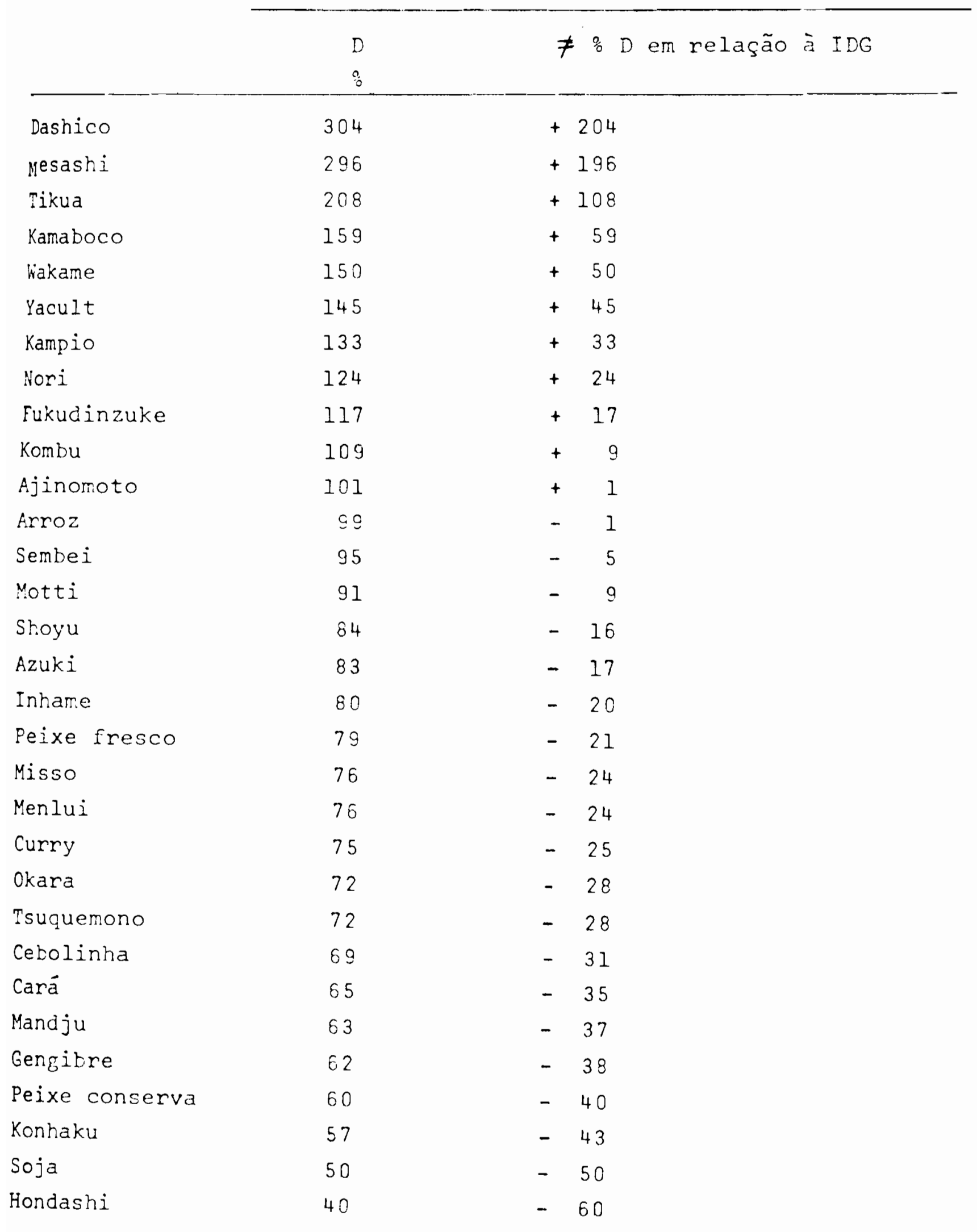


Continuesção... TAB 10

Alimentos $\mathrm{p}$. orientais
Porcentagem de citações das famílias $D$ em relação à IDG considerando $100 \%$

D

q $D$ em relação à IDG

8

$\begin{array}{lcc}\text { Tsukudani } & 39 & -61 \\ \text { Sake } & 38 & -62 \\ \text { Chä verde } & 27 & -73 \\ \text { Sunomoto } & 26 & -74 \\ \text { Tofu } & 24 & -76 \\ \text { Kinaco } & 23 & -77 \\ \text { oleo Eergelim } & 22 & -78 \\ \text { Ague } & 22 & -78 \\ \text { Leite de soja } & 21 & -79 \\ \text { Mirim } & 10 & -90 \\ \text { Umeboski } & 5 & -95 \\ \text { Gergelim } & 3 & -97 \\ \text { Chá oriental } & - & -\end{array}$




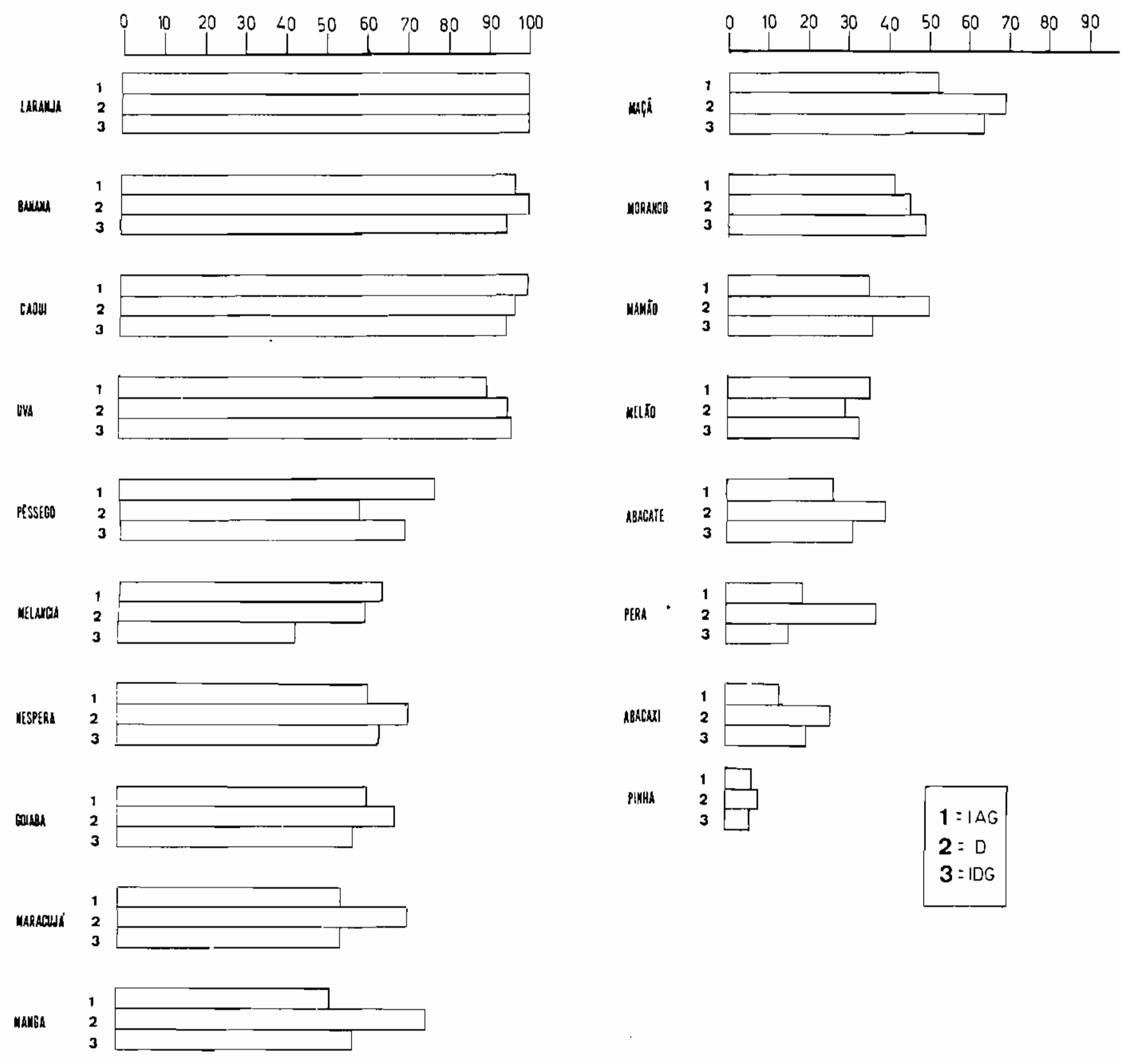

FIGURA 3 -APRESENTAÇÃO GRÁFICA DAS FRUTAS MENCIONADAS PELAS FAMILIAS ESTUDADAS- IAG(1); D(2) e IDG(3), DAQUELAS DE CONSUMO USUAL DURANTE O ANO 
8.3.3. O consumo de alimentos preponderantemente ociden tais

Da análise pareada dos resultados, entre os grupos IAG e D, depreende-se que houve diferença significativamen te maior para os $D$ no que se refere ao consumo dos alimentos preponderantemente ocidentais (TABELA 4).

Nota-se na TABELA 11 que os oito primeiros alimentos, alinhados em ordem de grandeza, consumidos pelos D, também o foram pelos IAG: óleo, açúcar refinado, café, alho, cebola, päo, margarina e pimenta.

o feijão, mediante o número de frequência citado ao ano (261, l dias) pelos $D$, denota que houve sua incorpora çāo na alimentaçāo neste grupo familiar. János IAG, apesar da sua longa permanéncia no Brasil de umas décadas, ainda se apre senta com frequências aquém dos seus descendentes (TABELA 11).

Entre as bebidas alcoólicasaque apresentou maior expressão númerica de frequência anual, foi a aguardente mencionada pelos IAG (TABELA 11).

Expressando esses resultados em termos percentuais (TABELA 12) poder-se-á ter idéia mais clara do grau de incorporação dos hábitos alimentares nacionais.

Seria de se esperar, que não houvesse diferen (TABELA 13)

ças marcantes entre os. IAG e ós IDG, vma vez que ambos são imi grantes isseis. Entretanto houve diferenças em consequēcias advindas dos momentos histónicos em que esses grupos deixaram sua terra natal. Assim os IAG sofreram a interferência fora do seu País, através de contacto abrupto com os hábitos alimen tares nacionais ao desembarcarem no Brasil.

Jâ os IDG, o contacto com os alimentos ocidentais foi, em parte, em sua pröpria terra de origem, convivencio 
com a ocidentalização alimentar, principalmente naqueles momentos circunstâncias, logo apös a II Guerra Mundial.

Como era de se esperar, a frequência pareada de menções anuais dos alimentos preponderantemente ocidentais entre os grupamentos familiares IDG e $D$, quando submetida ao tes te não-paramëtrico, com nível de significância $\alpha=5 \%$, mostrou diferença ". significante no sentido de maior consumo desta categoria por esses grupos (TABELA 4 ).

Dentre os alimentos preponderantemente ocidentais mencionados pelos IDG e $D$, estes últimos apresentaram maior frequència anual de : óleo, açūcar, pão, margarina, café,alho, feijão, chã mate, leite em pó, farinha de trigo, macarrão, cal do knor, chocolate, manteiga e banha.

Qualitativamente, nota-se portanto, que os IDG indicam sua preferência àqueles alimentos que jả conheceram anteriormente em seu país de origem.

0 consumo anual de feijão foi mais elevado entre os. D que entre os IDG. No entanto, a ingestão do aguarda dente foi maior para os IDG.

A FIGURA 6, representa o conjunto do comporta mento referente ao consumo anual de alimentos preponderantemen te ocidentais de 148 ao ano ou mais(equivale a uma vez por semana ou mais).

Portanto, a populaçāo de origem japonesa, nesta área de eștudo, encontra-se, em estágios díspares quanto à aqui siçāo de hảbitos alimentares do País adotado,estando os extremos entre os D e os IDG, e no intermediário, o grupo IAG.

8.3.4. Consumo de verduras e frutas sazonais

As mençōes, em percentuais, feịtas pelos grupos famíliares IAG, D e IDG sobre o consumo de verduras e frutas 
(FIgURAS 7 e 8) indicam que, os três segmentos dessa popula ção de japoneses utilizam. uma mescla das verduras e frutas habituais no oriente e ocidente.

Quanto às verduras (FIGURA 7), aquelas mais mencionadas, não apresentam maiores diferenças entre as familias IAG, D e IDG.

Talvez pudesse se suspeitar de algum tipo de influência que os $D$ tenham sofrido, devido as atividades agrícolas desenvolvidas pelos seus ancestrais no Brasil.

0 mesmo se pode: dizer quanto ao consumo de frutas (FIGURA 8). 
TABELA 11 - Diferenças absolutas de citações anuais dos alimentos preponderadamente ocidentais ( $p . o c i d e n t a i s)$, entre as familias isseis antes da guerra (IAG) e descendentes (D), dispostas segundo ordem de grandeza

Alimentos $\mathrm{p}$.

ocidentais
Freqüencia de citaçōes anuais/familia

$\operatorname{IAG}(a)$

$\mathrm{n}$
$D(b)$

$\mathrm{n}$
Diferença em $n$ absoluto entre familias IAG e D

$$
\neq(a-b)
$$

\begin{tabular}{|c|c|c|c|}
\hline Oleo & 365,0 & 365,0 & 0 \\
\hline Açúcar ref. & 365,0 & 356,7 & $+8,3$ \\
\hline Café & 344,8 & 338,9 & $+5,9$ \\
\hline Alho & 296,3 & 327,4 & $-31,1$ \\
\hline Cebola & 294,7 & 307,3 & $-17,6$ \\
\hline Pão & 280,9 & 309,1 & $-28,2$ \\
\hline Margarina & 276,1 & 316,9 & $-40,8$ \\
\hline Pimenta & 257,1 & 216,7 & $-40,4$ \\
\hline Leite Pó & 254,5 & 176,9 & $+77,6$ \\
\hline ovo & 248,9 & 261,1 & $-12,2$ \\
\hline Limão & 220,6 & 234,2 & $-13,6$ \\
\hline Chä mate & 200,2 & 229,0 & $-28,8$ \\
\hline Vinagre & 163,9 & 180,6 & $-16,7$ \\
\hline Feijão & 163,2 & 261,2 & $-98, c$ \\
\hline Suco de frutas & 161,7 & 131,8 & $+29,9$ \\
\hline Far. trigo & 148,6 & 103,2 & $+45,4$ \\
\hline Chá preto & 141,7 & 107,7 & $+34,0$ \\
\hline Leite fresco & 139,7 & 129,0 & $+10,7$ \\
\hline Batata-inglesa & 136,5 & 142,6 & $-6,1$ \\
\hline Macarrão: & 127,1 & 106,8 & $+20,3$ \\
\hline Carne bovina & 115,4 & 143,6 & $-28,2$ \\
\hline Aguardente & 111,8 & 24,5 & $+87,3$ \\
\hline Carne-aves & 71,6 & 80,9 & $-9,3$ \\
\hline $\mathrm{Mel}$ & 64,8 & 62,2 & $+2,6$ \\
\hline Refrigerante & 58,9 & 58,4 & $+0,5$ \\
\hline Mandioca & 44,1 & 44,6 & $-\quad 0,5$ \\
\hline Queijo & 43,0 & 61,1 & $-18,1$ \\
\hline Banha & 41,1 & 69,7 & $-28,6$ \\
\hline Açúcares-outros & 36,5 & 30,6 & $+\quad 5,9$ \\
\hline Caldo Knor & 33,9 & 93,6 & $-59,7$ \\
\hline
\end{tabular}


Continuaçäo...

TAB. 11

Alimentos $\mathrm{p}$. ocidentais
Frequência de citações anuais/família $\operatorname{IAG}(\mathrm{a})$

$\mathrm{n}$

32,1

30,6

Linguiça

Manteiga

Batata-doce

Leite Condensado

Embutidos-outros

Azeite

Iogurte

Salsicha

27,3

25,9

23,0

21,7

20,2

19,5

Maizena

18,1

Maionese

16,6

16,0

Beb.alcool:-outras 14,1

Cerveja

Massa tomate

Carne suina

Condimentos-outros

Mandioquinha

Fubá

Ervilha

Creme de leite

Carne seca

Fígado

Far. mandioca

Leguminosas-outras

Amendoim
11,9

11,7

9,7

8,3

7,1

5,6

5,3

3,5

0,8

0,8

0,6

0,4

0,2
$D(b)$

n

62,5

33,9

62,5

7,9

36,1

46,5

17,8

33,5

22,6

24,3

16,9

12,4

35,0

42,5

18,8

11,9

13,8

11,3

1,1

6,2

8,2

1,0

3,0

0,3

6,4
Diferença em $\mathrm{n}$ absoluto entre familias IAG e D $\neq(a-b)$
$-30,4$

$-3,3$

- 35,2

$+18,0$

$-13,1$

$-24,8$

$+\quad 2,4$

$-14,0$

$-\quad 4,5$

$-\quad 7,7$

$-0,9$

$+1,7$

$-23,1$

$-30,8$

$-9,1$

- 3,6

- 6,7

$-\quad 5,7$

$+\quad 4,2$

$-\quad 2,7$

- 7,4

- 0,2

- 2,4

$+\quad 0,1$

- 6,2 
TABELA 12 - Diferenças percentuais de citaçōes anuais de alimentos preponderadamente ocidentais ( $P$. ocidentais), considerando famílias isseis antes da Guerra

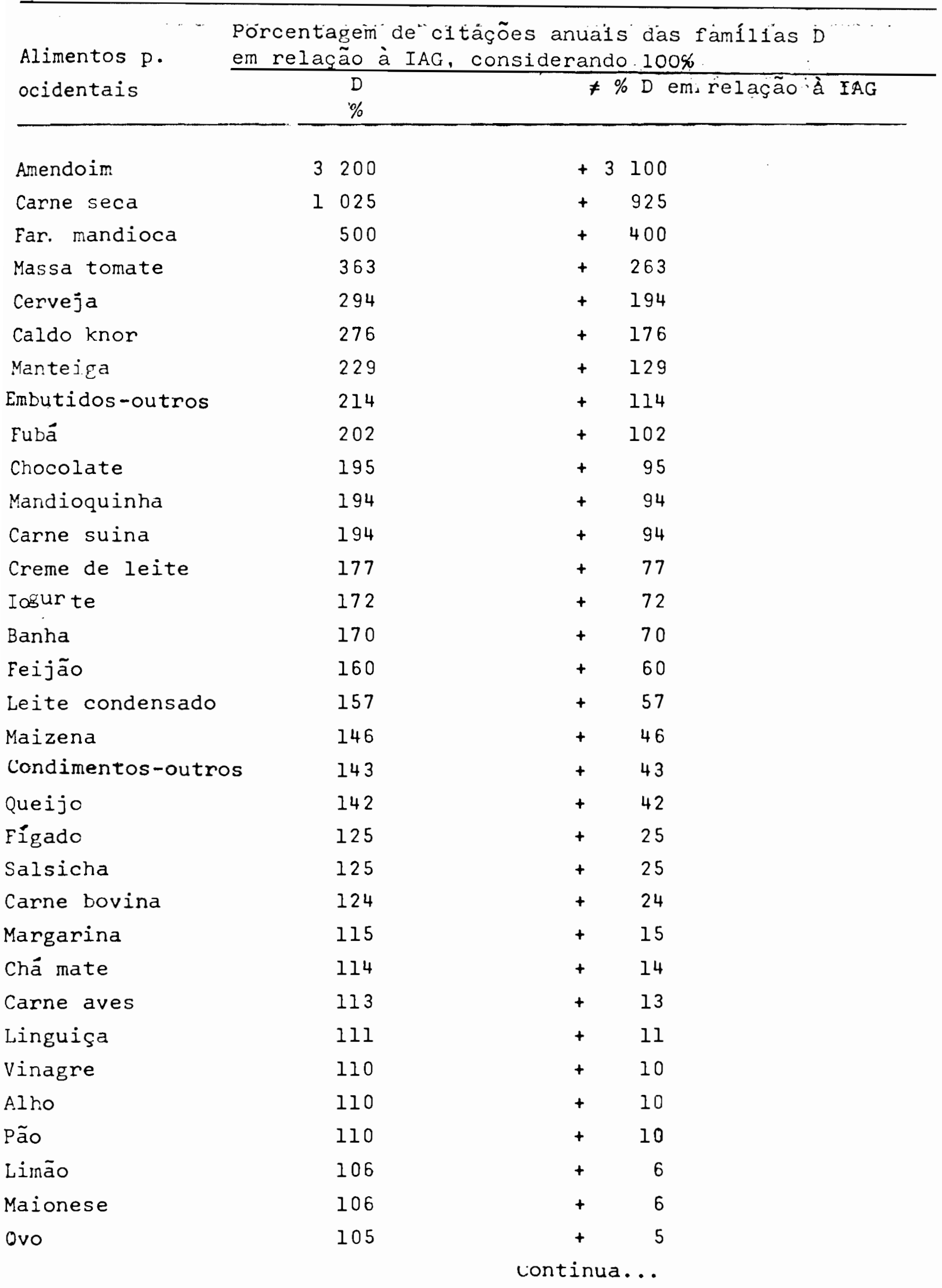


Continuação... TAB.12

\begin{tabular}{|c|c|c|}
\hline Alimentos $\mathrm{p}$. & $\mathrm{D}$ & $\neq: D$ em relação à IAG \\
\hline ocidentais & $q$ & \\
\hline
\end{tabular}

Batata-inglesa

104

Cebola

104

Mandioca

101

oleo

100

Refrigerante

99

Açúcar refinado

98

Café

98

Mel

96

+4
+

$+4$

$+1$

0

- 1

$-2$

Leite fresco

92

- 2

Azeite

88

- 4

Beb. alcool.-outras

88

$-8$

Macarrão

84

$-12$

Pimenta

84

- 12

$-16$

Acúcares-outros

84

$-16$

Suco de frutas

81

$-16$

chá preto

76

$-19$

Leguminosas-outras

75

$-24$

Leite pó

69

- 25

Far. trigo

69

- 31

Batata-doce

30

- 31

Aguardente

22

$-70$

Ervilha

21

$-78$

- 79 
TABELA 13- Diferenças em nümero ( $n$ ) absoluto das citações anuais dos alimentos preponderadamente ocidentais ( $p$. ociden tais), entre as familias "isseis": antes da guerra (IAG) e depois da guerra (IDG)

Alimentos $\mathrm{p}$. ocidentais
Frequêencia de citações anuais/famillia $\operatorname{IAG}(\mathrm{a})$

n
$\operatorname{IDG}(\mathrm{b})$

$\mathrm{n}$
Diferença em $\mathrm{n}$ absoluto entre familias IAG e IDG. $(a-b)$

$n$

\begin{tabular}{|c|c|c|c|c|}
\hline oleo & 365,0 & 363,7 & + & 1,3 \\
\hline Açücar ref. & 365,0 & 344,5 & + & 20,5 \\
\hline Café & 344,8 & 288,3 & + & 56,5 \\
\hline Alho & 296,3 & 278,1 & + & 18,2 \\
\hline Cebola & 294,7 & 327,8 & - & 33,1 \\
\hline Pão & 280,9 & 307,4 & - & 26,5 \\
\hline Margarina & 276,1 & 306,0 & - & 29,9 \\
\hline Pimenta & 257,1 & 223,9 & + & 33,2 \\
\hline Leite em pó & 254,5 & 108,6 & + & 145,9 \\
\hline Ovo & 248,9 & 291,6 & - & 42,7 \\
\hline Limão & 220,6 & 255,6 & - & 35,0 \\
\hline Chá mate & 200,2 & 136,8 & + & 63,4 \\
\hline Vinagre & 163,9 & 125,5 & + & 38,4 \\
\hline Feijão & 163,2 & 138,8 & + & 24,4 \\
\hline Suco de frutas & 161,7 & 131,1 & + & 30,6 \\
\hline Far. trigo & 148,6 & 123,1 & + & 25,5 \\
\hline chá preto & 141,7 & 80,1 & + & 61,6 \\
\hline Leite fresco & 139,7 & 161,9 & - & 22,2 \\
\hline Batata-inglesa & 136,5 & 180,6 & - & 44,1 \\
\hline Macarrão & 127,1 & 85,3 & + & 41,8 \\
\hline Carne bovina & 115,4 & 156,0 & - & 40,6 \\
\hline Aguarderite & 111,8 & 115,7 & - & 3,9 \\
\hline Carne aves & 71,6 & 109,5 & - & 37,9 \\
\hline Mel & 64,8 & 61,6 & + & 3,2 \\
\hline Refrigerante & 58,9 & 77,5 & - & 18,6 \\
\hline Mandioca & 44,1 & 26,7 & + & 17,4 \\
\hline Queijo & 43,0 & 73,2 & - & 30,2 \\
\hline Banha & 41,1 & 17,6 & + & 23,5 \\
\hline Açúcar-outros & 36,5 & 73,8 & - & 37,3 \\
\hline Caldo Knor & 33,9 & 45,2 & - & 11,3 \\
\hline
\end{tabular}


Continuação TAB.13

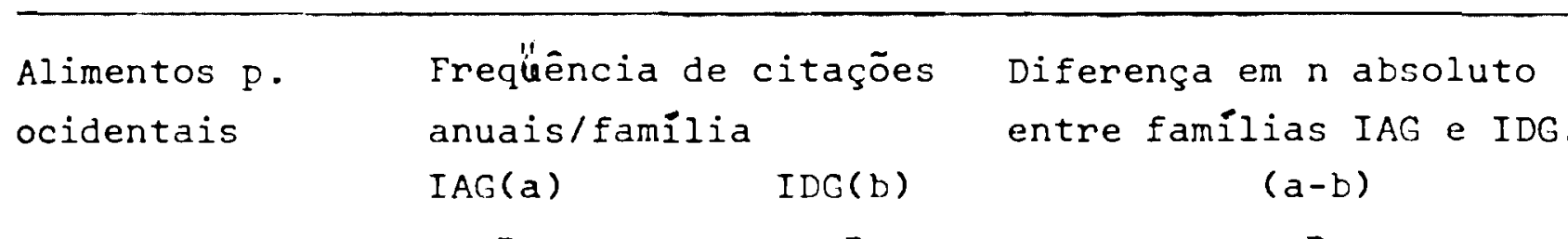

n

n

n

\begin{tabular}{|c|c|c|c|c|}
\hline Chocolate & 32,1 & 40,1 & - & 8,0 \\
\hline Linguiça & 30,6 & 18,0 & + & 12,6 \\
\hline Manteiga & 27,3 & 24,6 & + & 2,7 \\
\hline Batata-doce & 25,9 & 18,5 & + & 7,4 \\
\hline Leite condensado & 23,0 & 21,3 & + & 1,7 \\
\hline Embutidos-outros & 21,7 & 36,6 & - & 14,9 \\
\hline Azeite & 20,2 & 14,2 & + & 6,0 \\
\hline Iogurte & 19,5 & 18,6 & + & 0,9 \\
\hline Salsicha & 18,1 & 31,9 & - & 13,8 \\
\hline Maizena & 16,6 & 19,0 & - & 2,4 \\
\hline Maionese & 16,0 & 23,7 & - & 7,7 \\
\hline Beb.Alcool.-outros & 14,1 & 36,6 & - & 22,5 \\
\hline Cerveja & 11,9 & 42,1 & - & 30,2 \\
\hline Massa tomate & 11,7 & 12,5 & - & 0,8 \\
\hline Carne suina & 9,7 & 14,8 & - & 5,1 \\
\hline Condimento-outros & 8,3 & 5,2 & + & 3,1 \\
\hline Mandioquinha & 7,1 & 4,8 & + & 2,3 \\
\hline Fubá & 5,6 & 1,0 & + & 4,6 \\
\hline Ervilha & 5,3 & 5,1 & + & 0,2 \\
\hline Creme de leite & 3,5 & 4,1 & - & 0,6 \\
\hline Carne seca & 0,8 & 0,6 & + & 0,2 \\
\hline Fígado & 0,8 & 0,6 & + & 0,2 \\
\hline Far. de Mandioca & 0,6 & 0,1 & + & 0,5 \\
\hline Leguminosa-outras & 0,4 & - & + & 0,4 \\
\hline Amendoim & 0,2 & 3,7 & - & 3,5 \\
\hline
\end{tabular}


TABELA 14\%- Diferenças percentuais das citações anuais dos alimentos preponderadamente ocidentais ( $\mathrm{p}$. ocidentais), considerando as famílias IAG como $100 \%$

Alimentos $\mathrm{p}$. ocidentais
Porcentagem de citações das famílias IDG em rela ção à IAG considerando 100 q

IDG

\# \& IDG em relação à IAG

\&

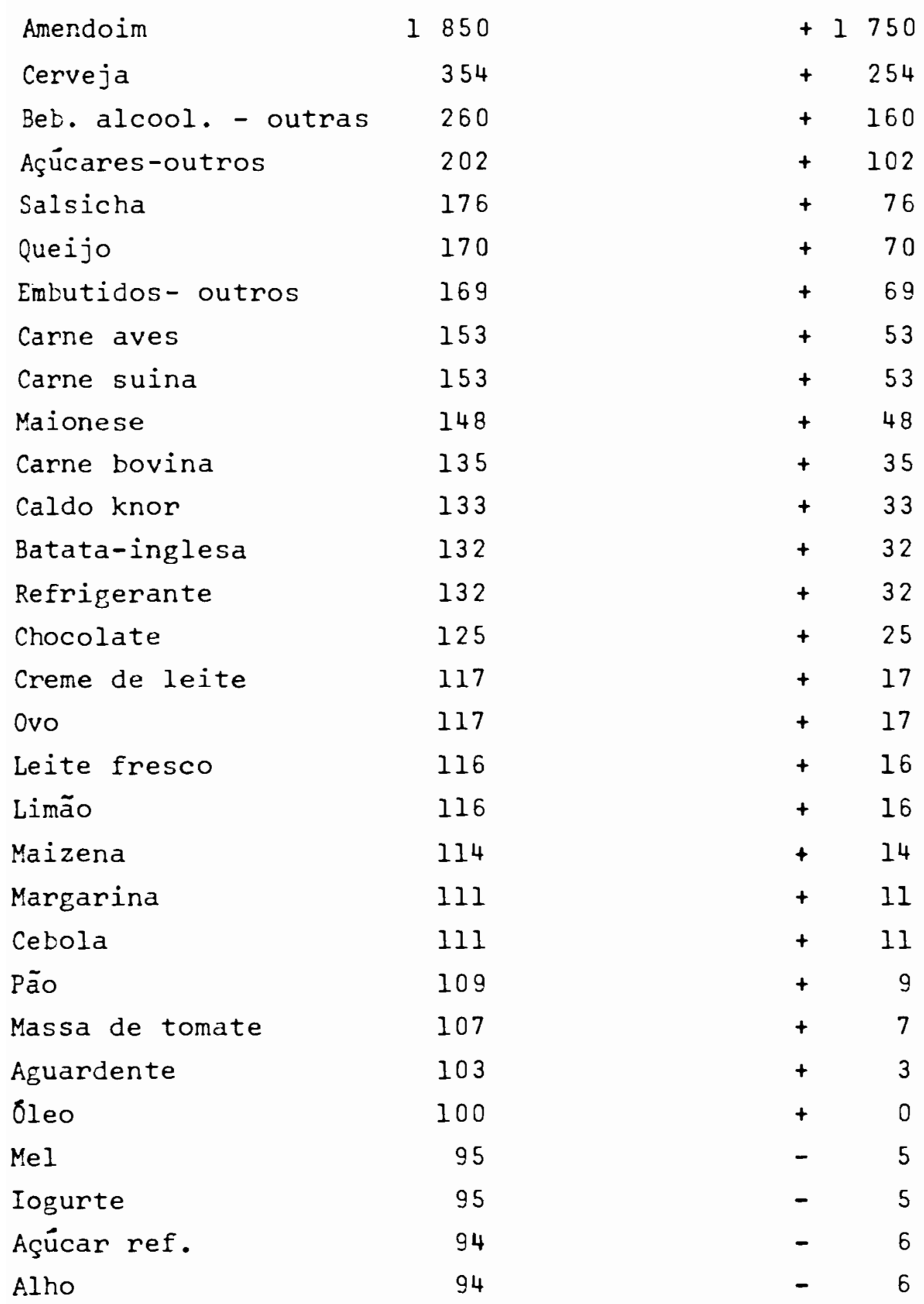


Continuação... TAB, 14

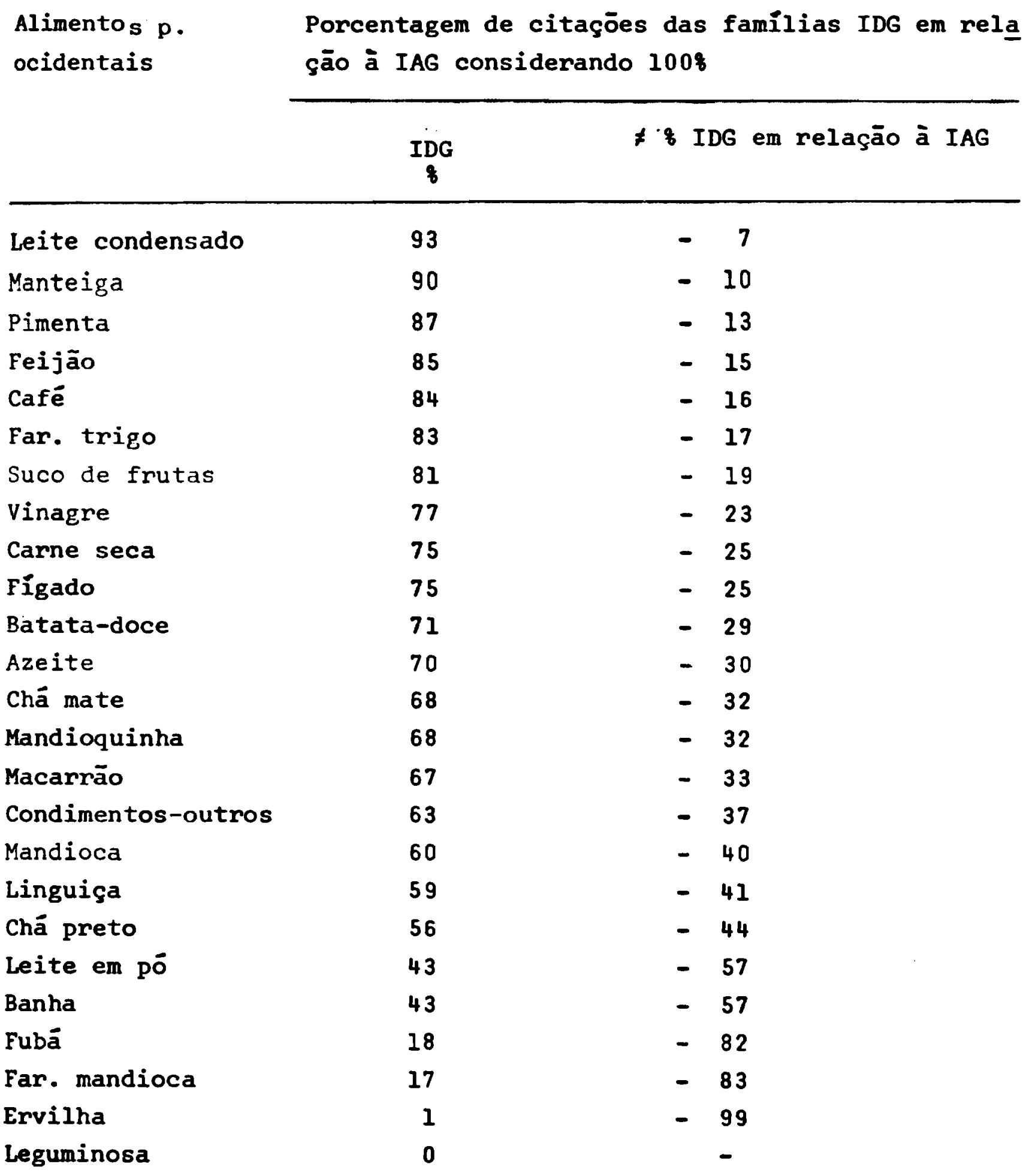


TABELA 15 - Diferenças em número absoluto, das citações anuais dos alimentos preponderadamente ocidentais (p.ocidentais), entre as familias isseis depois da guerra (IDG) e descendentes ( $D$ ), segundo ordem de grandeza

\begin{tabular}{llc}
$\begin{array}{l}\text { Alimentos p. } \\
\text { ocidentais }\end{array}$ & $\begin{array}{l}\text { Frequência de citações } \\
\text { anuais/familia }\end{array}$ & $\begin{array}{c}\text { Diferença em n absoluto } \\
\text { entre famílias IDG e D } \\
\text { IDG(a) }\end{array}$ \\
$n$ & $D(b)$ & $(a-b)$ \\
& $n$ & $n$ \\
\hline
\end{tabular}

\begin{tabular}{|c|c|c|c|}
\hline סleo & 363,7 & 365,0 & $-\quad 1,3$ \\
\hline Açücar ref. & 344,5 & 356,7 & $-12,2$ \\
\hline Cebola & 327,8 & 307,3 & $+20,5$ \\
\hline Pão & 307,4 & 309,1 & $-\quad 1,7$ \\
\hline Margarina & 306,0 & 316,9 & $-10,9$ \\
\hline Ovo & 291,6 & 261,1 & $+30,5$ \\
\hline Café & 288,3 & 338,8 & $-50,6$ \\
\hline Alho & 278,1 & 327,4 & $-49,3$ \\
\hline Limão & 255,6 & 234,2 & $+21,4$ \\
\hline Pimenta & 223,9 & 216,7 & $+7,2$ \\
\hline Batata-inglesa & 180,6 & 142,6 & $+38,0$ \\
\hline Leite fresco & 161,9 & 129,0 & $+32,9$ \\
\hline Carne bovina & 156,0 & 143,6 & $+12,4$ \\
\hline Feijão & 138,8 & 261,2 & $-122,4$ \\
\hline Chá mate & 136,8 & 229,0 & $-92,2$ \\
\hline Suco de frutas & 131,1 & 131,8 & $-\quad 0,7$ \\
\hline Leite em pó & 125,5 & 180,6 & $-55,1$ \\
\hline Vinagre & 125,5 & 103,2 & $+19,9$ \\
\hline Aguardente & 115,7 & 24,5 & $+91,2$ \\
\hline Far. trigo & 123,1 & 176,9 & $-51,4$ \\
\hline Carne aves & 109,5 & 80,9 & $+28,6$ \\
\hline Macarrão & 85,3 & 106,8 & $-21,5$ \\
\hline Chã preto & 80,1 & 107,7 & $-27,6$ \\
\hline Refrigerante & 77,5 & 58,4 & $+19,1$ \\
\hline Açúcar-outros & 73,8 & 30,6 & $+43,2$ \\
\hline Queijo & 73,2 & 61,1 & $+12,1$ \\
\hline Mel & $61+6$ & 62,2 & $-\quad 0,6$ \\
\hline Caldo knor & 45,2 & 93,6 & $-48,4$ \\
\hline Cerveja & 42,1 & 35,0 & $+7,1$ \\
\hline Chocolate & 40,1 & 62,5 & $-22,4$ \\
\hline
\end{tabular}


continuação ... TALj.15

Alimento $\mathrm{p}$.

ocidentais
Frequéncia de citaçōes

anuais/familia

$\operatorname{IDG}(a)$
$D(b)$

$\mathrm{n}$
Diferença em $n$ absoluto entre familias IDG e D

$$
(a-b)
$$

\begin{tabular}{|c|c|c|c|}
\hline Beb.alcool.-outras & 36,6 & 12,4 & $+24,2$ \\
\hline Embutido-outros & 36,6 & 46,5 & 9,9 \\
\hline Salsicha & 31,9 & 22,0 & 9,3 \\
\hline Mandioca & 26,7 & 44,6 & $-\quad 17,9$ \\
\hline Manteiga & 24,6 & 62,5 & 37,9 \\
\hline Maionese & 23,7 & 16,9 & 6,8 \\
\hline Leite condensado & 21,3 & 36,1 & $-\quad 14,8$ \\
\hline Maizer:a & 19,0 & 24,3 & 5,3 \\
\hline Iogurte & 18,6 & 33,5 & $-\quad 14,9$ \\
\hline Batata-doce & 18,5 & 7,9 & $+10,6$ \\
\hline Linguif̧a & 18,0 & 33,9 & 15,9 \\
\hline Banha & 17,6 & 69,7 & 52,1 \\
\hline Carne suina & 14,8 & 18,8 & 4,0 \\
\hline Azeite & 14,2 & 17,8 & 3,6 \\
\hline Yassa tomate & 12,5 & 42,5 & $-30,0$ \\
\hline Condimento-olitros & 5,2 & 11,9 & 6,7 \\
\hline Ervilta & 5,1 & 1,1 & 4,0 \\
\hline Mandioquinha & 4,8 & 13,8 & 9,0 \\
\hline Crene de leite & 4,1 & 6,2 & 2,1 \\
\hline Amendoim & 3,7 & 6,4 & 2,7 \\
\hline Fubá & 1,0 & 11,3 & $-10,3$ \\
\hline Carne seca & 0,6 & 8,2 & 7,6 \\
\hline Fígado & 0,6 & 1,0 & 0,4 \\
\hline Far. Mandioca & 0,1 & 3,0 & 2,9 \\
\hline Leguminosa-outras & 0,0 & 0,3 & 0,3 \\
\hline
\end{tabular}


TABELA 16 - Diferenças percentuais das citações anuais dos alimentos preponderadamente ocidentais (p.ocidentais), considerando as familias IDG como $100 \%$

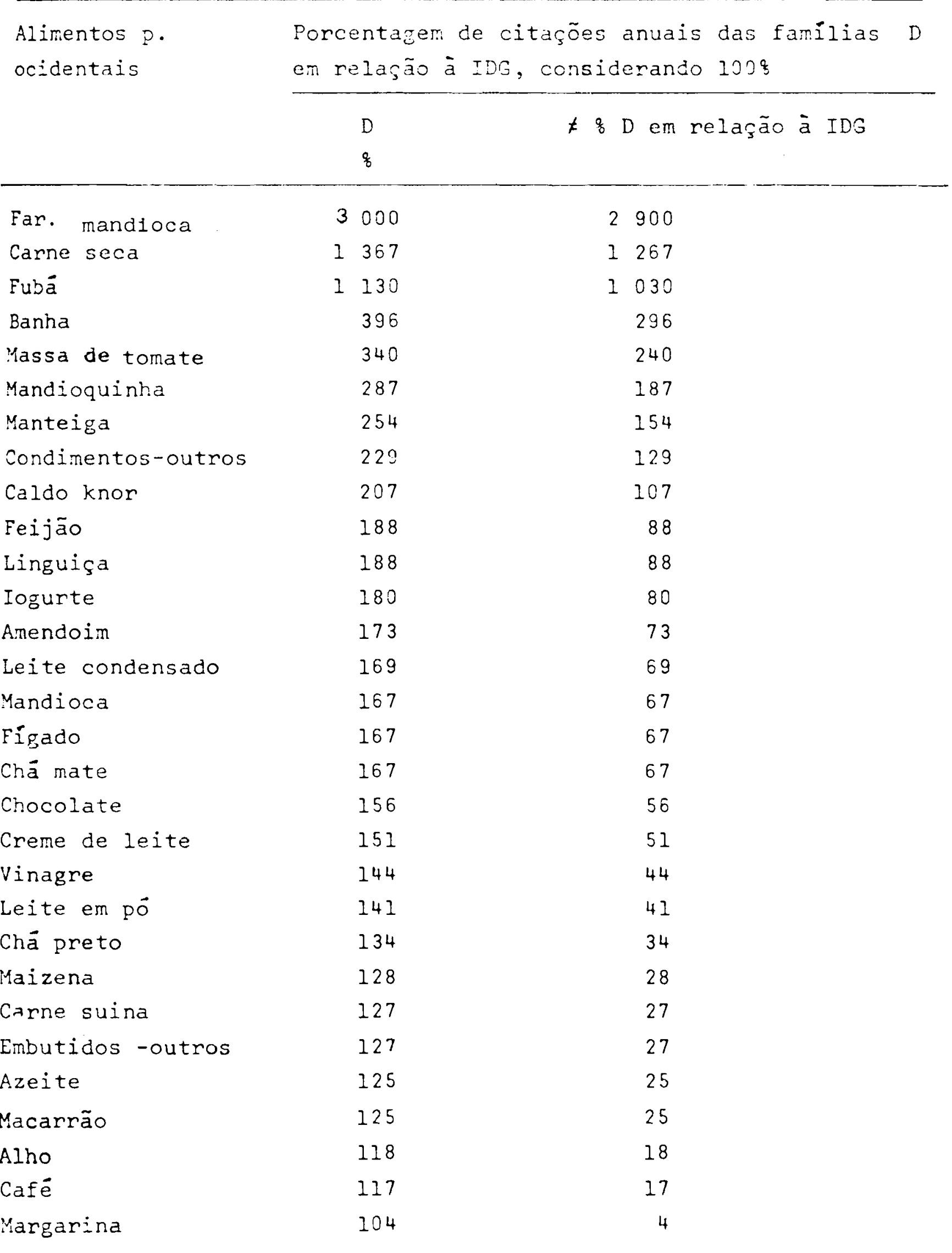


Continuação ... TAB. 16

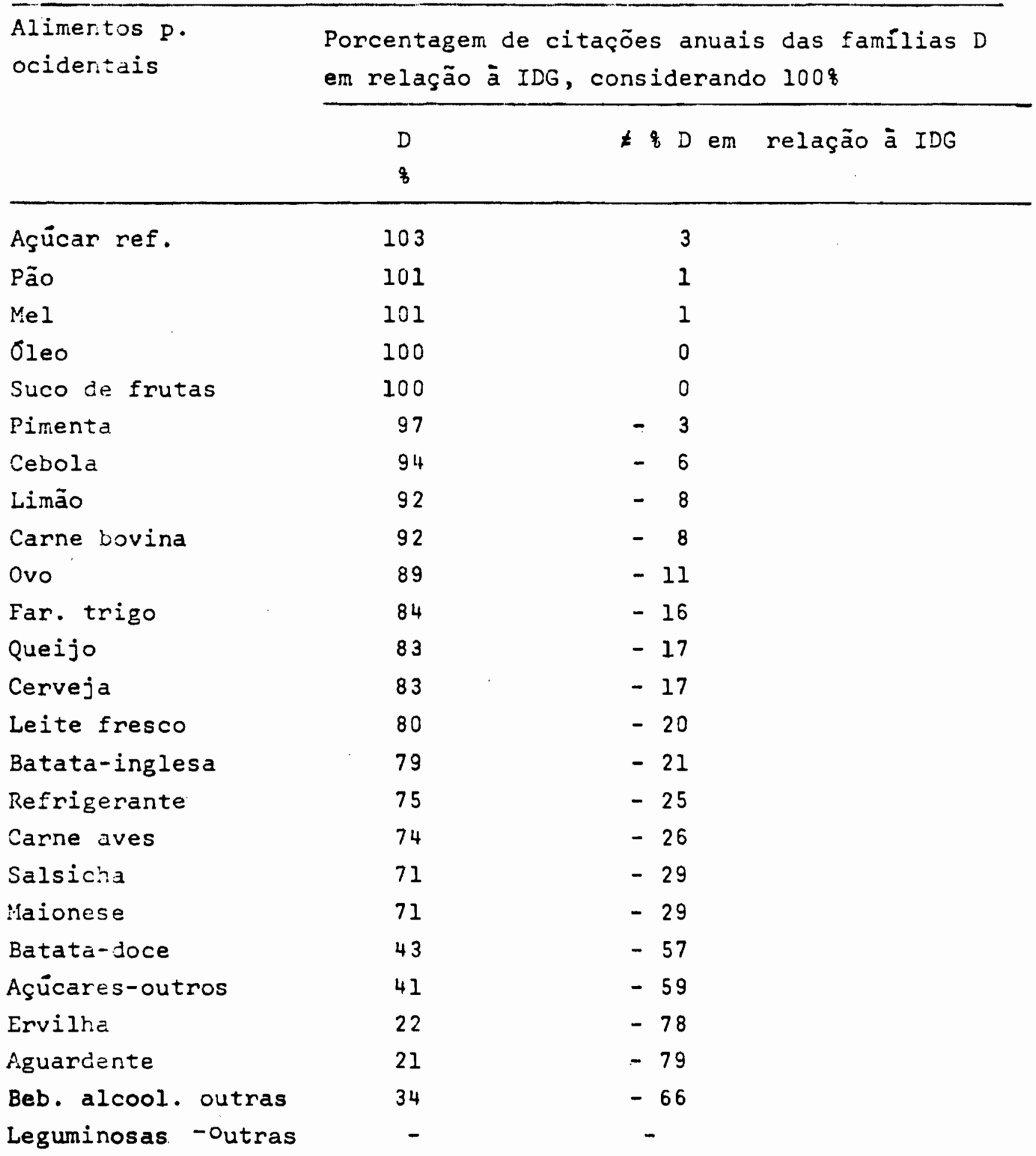



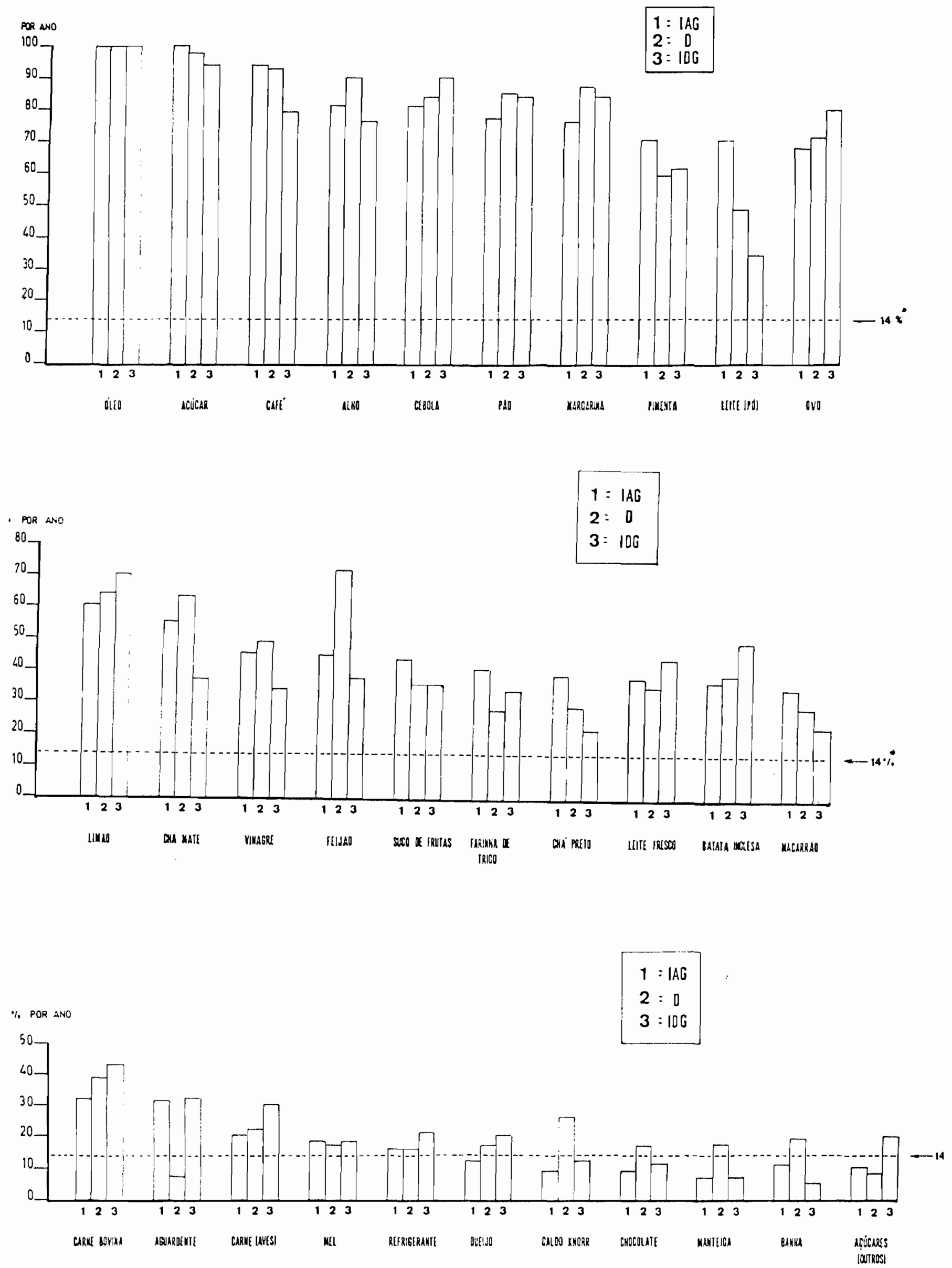

FIGURA 6- APRESENTAÇÃO GRÁFICO DOS ALIMENTOS PREPONDERANTEMENTE OCIDEN TAIS COM FREQUUENCIA ANUAL DE MENÇÕES, ACIMA DE UMA VEZ POR SE-IAANA (EM PERCENTUAL), SEGUNDO OS GRUPAMENTOS FAMILIARES: IAG(1); $D(2)$ e IDG(3)

* 14 \% equivale a 1 vez por semana ao ano ou 52 dias ao arlu. 

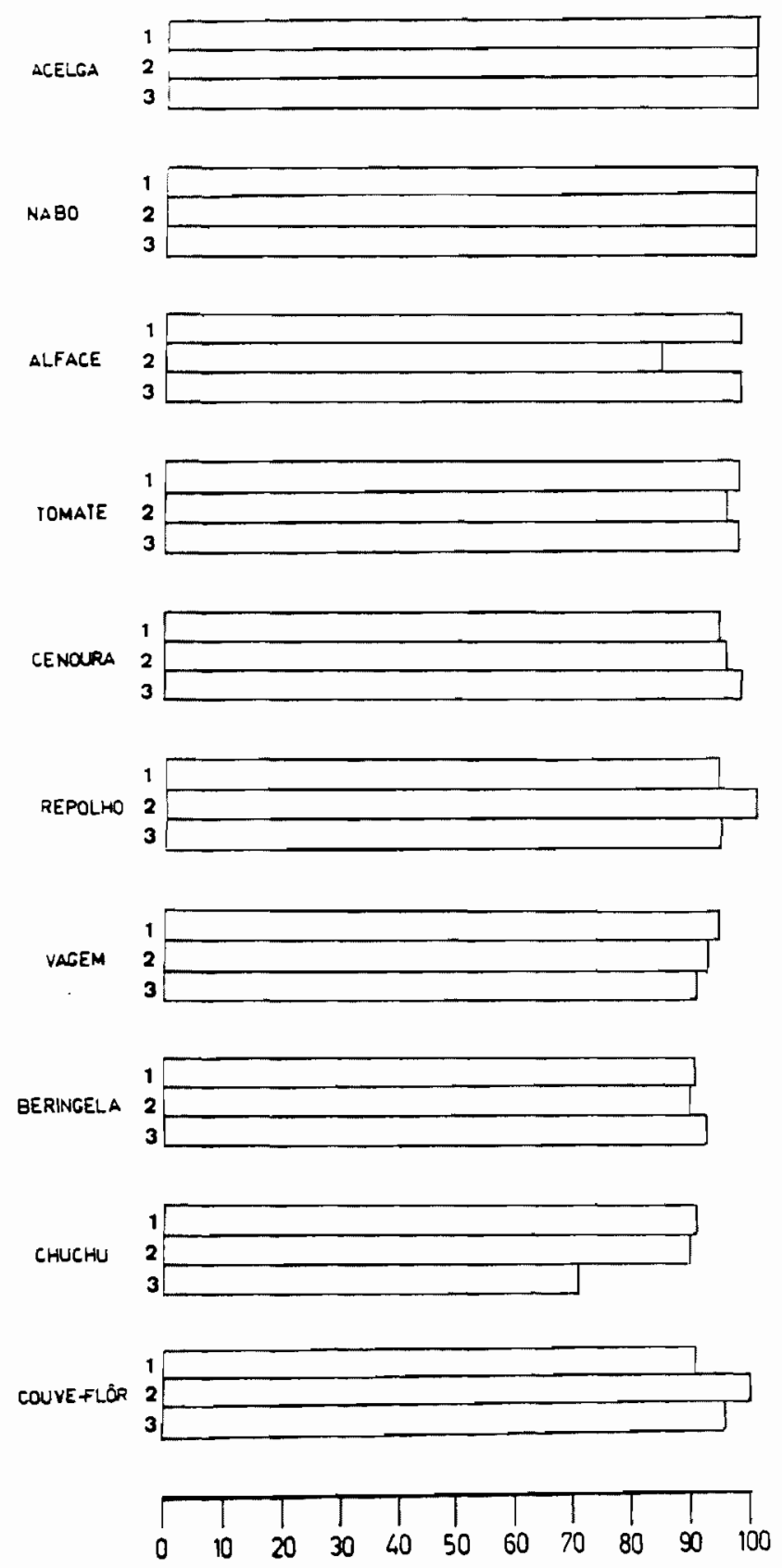

$\%$ do no de famílias
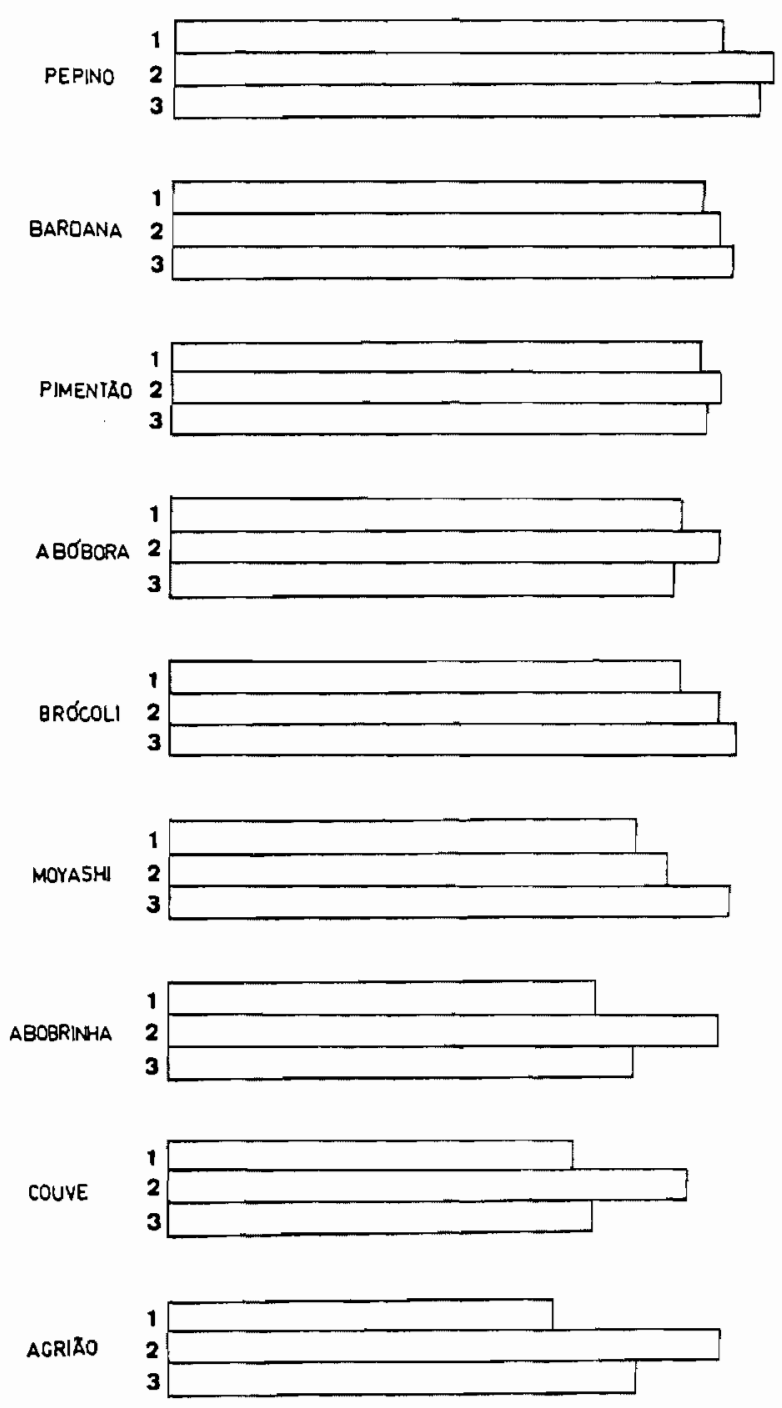

\section{\begin{tabular}{|lll|}
\hline $1-I A G$ & $2-D$ & $3-I D G$ \\
\hline
\end{tabular}}

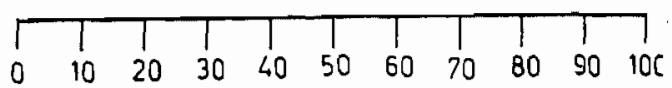

$\%$ do $n^{0}$ de familias

Continua...

FICURA 7- APRESENTAÇÃO GRÁFICA DAS VERDURAS MENCIONADAS (EM PERCEN-; TUAL) PELAS FAMILIAS PESQUISADAS -IAG(1);D(2) e IDG(3). DAQUELAS DE CONSUMO USUAL DURANTE O ANO. 
Continuação...
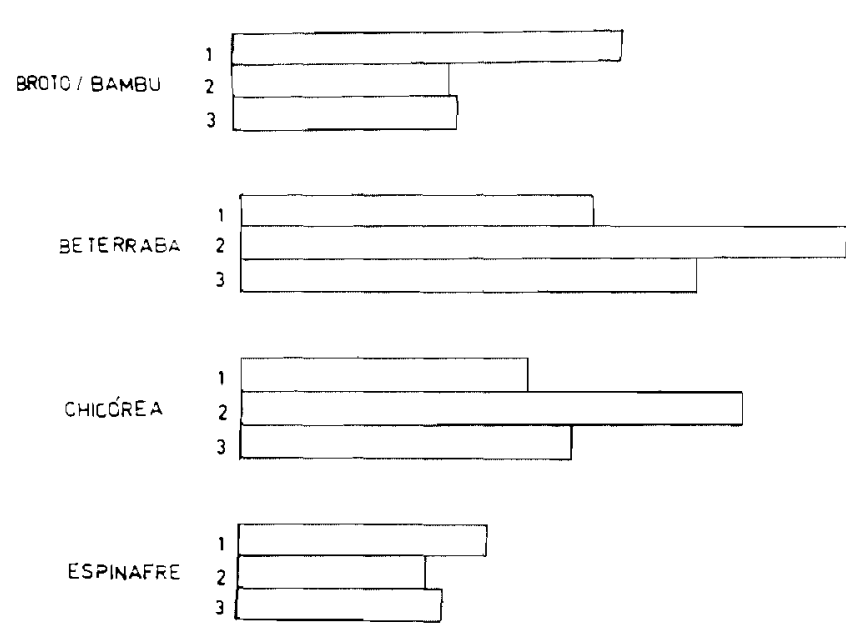

RAIZ / LOTUS 121

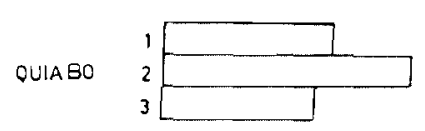

GILO

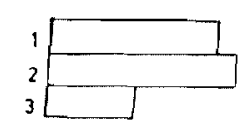

ERVILMAIVAGEM 12

Rotorsamambaia 2 \begin{tabular}{l}
\hline \\
\end{tabular}

NIRA'

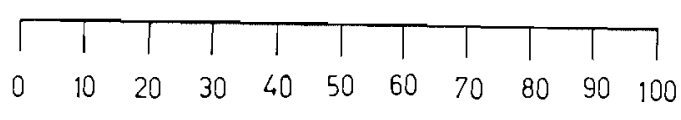

$\%$ DO NE de famílas

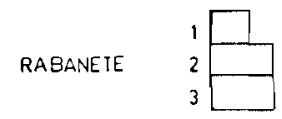

MILHO VERDE $\quad \begin{array}{ll}2 \\ 2\end{array}$

COGUMELO

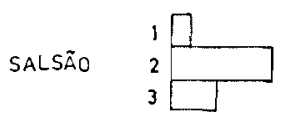



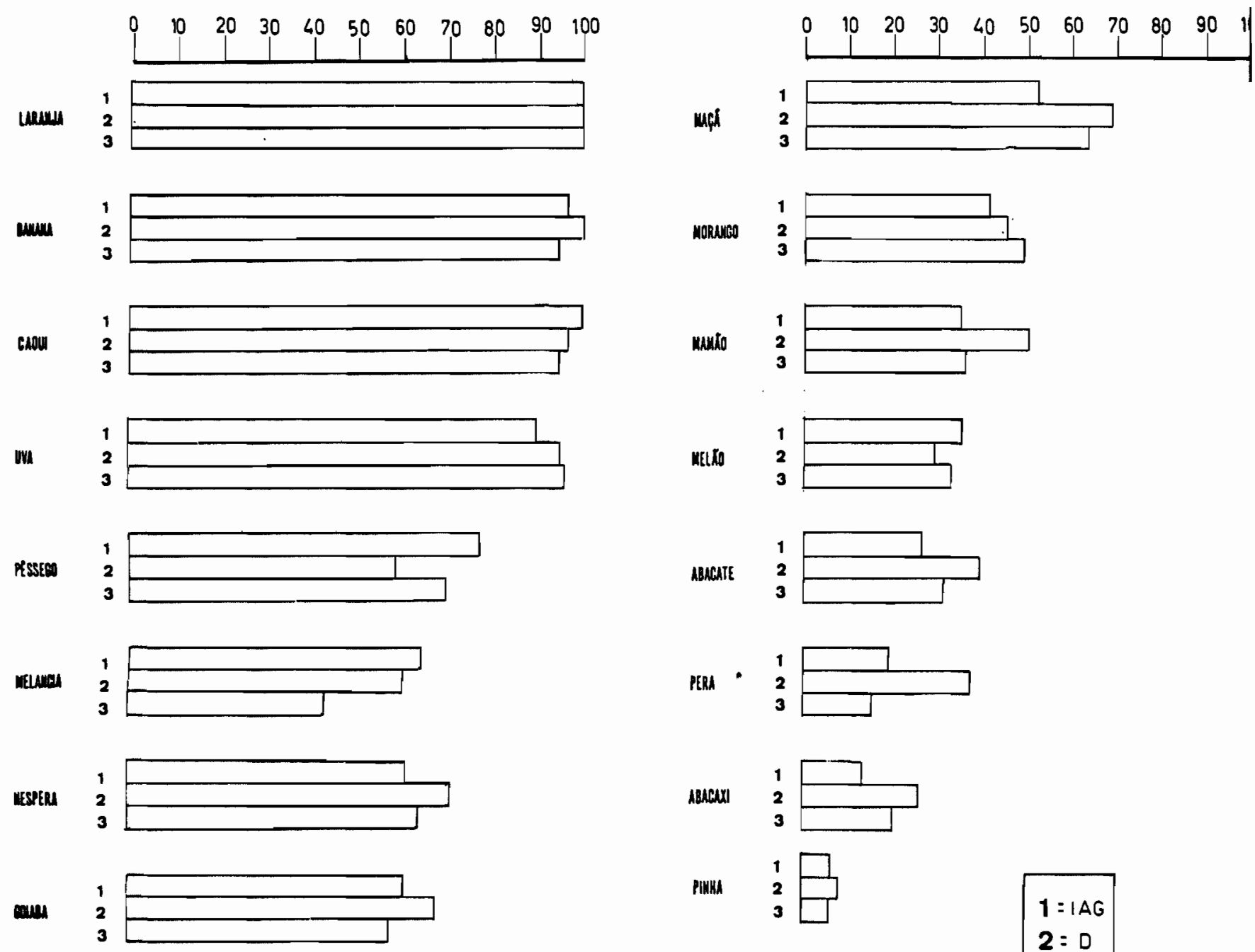

PIWII $\quad \begin{array}{ll}1 & 2 \\ & 3\end{array}$
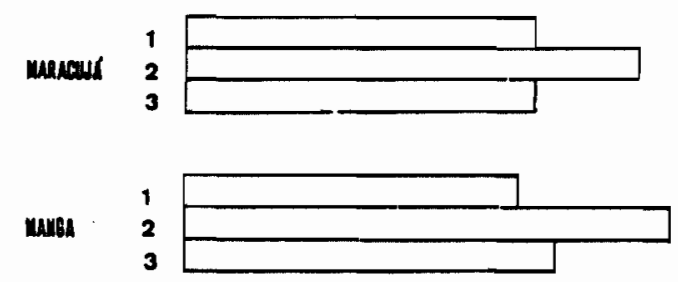

FIGURA 8 -APRESENTAÇÃO GRÅFICA DAS FRUTAS MENCIONADAS PELAS FAMILIAS ESTUDADAS- IAG(1); $D(2)$ e IDG(3), DAQUELAS DE CONSUMO USUAL DURANTE $O$ ANO 
9. DISCUSSÃO E COMENTRRIO

Um dos instrumentos recomendados para melhorar o es tado nutricional de comunidades è a implantação de programas de educação alimentar, cujos objetivos precípuos são os de difundir conhecimentos e modificar atitudes e präticas alimentares da população-alvo. ${ }^{11}$

Autores, tais como EURGESS ${ }^{3}$, DICKINS ${ }^{0}$, GARINE ${ }^{15}$, GUSSOW e CONTENTO ${ }^{17}$, MEAD ${ }^{30}$, TODHUNTER ${ }^{47}$ e outros tantos espe cialistas, preocupados en desenvolver programas alimentares, identificaram resistências relativas à aceitação de suas ativi dades de intervenção alimentar. Observaram que a forma como os indivíduos selecionam, consomem e utilizam os alinentos estava interligada à sua cultura e ao estágio industrial da ärea em que residiam.

YUDKIN ${ }^{50}$, en: 1978, observara que, normalmente, os häbitos alimentares são considerados como sendo mais ou menos constantes, porém estão em permanente mudança. Os fatores de terminantes dos hábitos alimentares são, entre outros, a cultú ra, a religião, a estrutura agrícola, as facilidades na oferta de aquisição dos alimentos, a renda familiar, bem como, as facilidades e técnicas de infraestrutura. Também, interferen nas preferencias familiares e individuais o contacto com a vizi nhança e comerciantes, ou, ainda, os escolares podem ainda car rear à sua família novas concep̧cões sobre o valor nutricional dos alimentos, assim como informações sobre o que comem os ou tros povos.

REID 42,43 considera que um campo fértil e informativo para/o estudo de mudanças de atitudes comportamentais é, certamente, oferecido pelos grupos populacionais de etnias diferen- 
ses com costumes distintos, quando migram para äreas de hábitos diversos, submetendo-se, aí, a um processo de adaptação às novas condiçōes, evidenciardo, assim, aqueles comportamentos mais susceptíveis às mudanças, bem cono os mais resistentes a elas, isto $\vec{e}$, os componentes mais ou menos incorporados às estruturas culturais anteriores.

Na realidade, sempre há troca de hābitos, pois se a imigração for de grande massa e de grupos com nível cultural superior ao da populaçāo local, esta pode incorporar novos hábitos alimentares. 25,26

MUIR $^{35}$ sugere os estudo futuros devem ser levados a efeito em correntes migratónias mais recentes, onde o autor acredita que possam oferecer promissoras informaçōes sobre'o comportamento dos hābitos alimentares como exemplo citam-os descendentes indianos nas comunidades paquistanesas; indianos em FIJI e adjacēncias; comuniciades japonesas e européias no Brasil; europeus na Argentina, indianos orientais, hindús e pa quistaneses no Reino Unido; micrantes da Europa Central e Se tentrional para o Canadá e a população chinesa em Hongcong e Ilha Formosa.

Estudos de grupos étnicos que se transladaram mais re centemente para outro meio ambiente, podem mostrar resgate de uma tradição já desaparecida no país de origem, mas que pode ter persistido entre migrantes que deixaram a pätria-māe em é poca mais distantes? 19

Nessa linha de raciocínio, as pesquisas atuais temse direcionado para os aspectos sócioculturais, a fim de mensurar em modificações do estilo de vida.

Em $1964, \mathrm{HEAD}^{31}$ fez uma análise retrospectiva da atuação da Comissão de Häbitos Alimentares. Seus resultados le varam à conclusão de que o assunto não se esgotara, estando em 
pleno vigor à procura da identificação dos fatores causais que atuam sobre os hábitos alimentares.

o Instituto Americano de Nutrição ${ }^{51}$, em 1977, definiu uma nova disciplina emergente no campo de nutrição, denot minada "Antropologia Nutricional" como senco o estudo sóciocultural, voltado para a identificação de alimentos e dietas que afetam a saúde e o estacio nutricional da população.

No Brasil, os imigrantes japoneses, embora consti tuindo um grupo minoritário, têm forte concentração no Estado de são paulo. 8

Tendo em vista a proposição de MUIR quanto ao inter resse por incentivar pesquisas sobre os aspectos de adaptação cultural, ainda pouco explorados em nosso meio, esse grupo ofe rece campo fërtil de estudos. A coexistência de trés segmentosIAG, D e IDG- permite uma anälise de continuidade das mudanças, de forma a se obterem informações consistentes dos fatores cau sais da dinâmica dos häbitos alimentares dessa população, quan do integrada ao sistema ecológico local e sujeita às tradiçöes culturais nacionais.

Na presente pesquisa, ao se tomar segmentos da popu lação de origem japonesa, residentes em um mesmo meio ambiente, observou-se que appresentavam certo nümero de alimentos de uso comum entre eles. Verificou-se que os alimentos preponderantemente orientais mais citados, durante um ano foram: arroz,ajinomoto, shoyu, misso, cebolinha e tsuquemono.

No confronto deste resultado com os dados obtidos em pesquisa anterior levada a efeito em área paulista de expansão cafeeira (municípios de Getulina e Guaimbê), a cerca de $500 \mathrm{~km}$ da Capital, constatou-se que esses mesmos alimentos orientais aparecem, tanbém, como os mais freqüentemente mencionados 24 . Uma vez que, duas áreas tão díspares, apresentaran coincidên cia na nreferência alimentar, pode-se inferir que esses 
alimentos preponderantemente orientais sāo os componentes mais resistentes, anteriormente incorporados às estruturas cul turais da colónia japonesa.

Ao se fazer, no presente estudo, uma observaçāo comparativa entre os grupos IAG, D e IDG, quanto aos häbitos alimentares orientais, depreende-se que os $\mathrm{D}$ aproximam-se quantita tivamente mais dos IAG do que dos IDG. Naturalmente, como co menta NOGUEIRA ${ }^{38}$, OS D conviveram em núcleos interioranos fecha dos, sofrendo, assim, forte influência da cultura dos "isseis" criados no Japão, durante a era Meiji.

Porém, ao se fazer a análise comparativa entre as menções anuais de alimentos orientais nos grupamentos familiares IAG e IDG, estes últimos ainda apresentam forte influência dos hábitos alimentares orientais. Em parte, isto se justifica, uma vez que os IDG, ao chegarem no Brasil, jä encontraram, no mercado, muitos alimentos japoneses por aqui industrializados, fato este que não aconteceu quando aqui chegaram os IAG. NOGUEIRA 39 destaca, ainda, que os IAG quando embar cavam para o Brasil thes era terminantemente proibido o transporte de quaisquer tipos de alimento para posterior consumo. Assim, quando os colonos japoneses, ao adentrarem pelo interior de Sāo Paulo, em contacto direto com a realidade nacional, não tiveram outra opção alimentar se não a local.

Os condimentos- o shoyu e o misso, tão importantes no preparo da alimentação japonesa, estiveram ausentes nas refeiçōes dos IAG durante longo tempo. Mais tarde, com o plantio da soja, houve o seu retorno à mesa dos japoneses.

O abandono. da alimentação tradicional japonesa pode rá ser melhor observado na diminuição da frequêencia anual : de consumo dos alimentos orientais pelo grupo D, em relação ao do IAG. Houve, por exemplo, o desaparecimento, praticamente total, 
do chá oriental, leite de soja e okara.

Alimentos que os IAG já haviam retomado em seu cardap̄io habitual, eram também utilizados pelos $D$, embora com fre qüência sensivelmente menor. E que põe em evidência a TABELA. 6.

Observa-se que foram os condimentos aqueles que sofreram maior abandono, caracterizando, assim, uma mudança drás tica no preparo da alimentação e, portanto, talvez no paladar.

Enquanto os IAG tiveram sua ocidentalização alimentar, promovida por um conjunto de alimentos encontrados, na época, na população brasileira local, os IDG, por um lado, rece beram, jã no Japão, alimentos ocidentais fornecidos por outras origens da cultura ocidental. Por outro lado, ao chegarem ao Brasil, encontraram jā uma estrutura sedimentada de suprimento para os alimentos orientais.

Se, na realidade, as diferenças quantitativas foram mínimas, o mesmo não se poderia dizer das espécies de alimen-: tos ocidentais introduzidos nesses dois grupos de imigrantes.

Notou-se que a aguardente foi mais citada entre os IAG que entre os D. Talvez, o tipo de educação em que foram crị ados os $D$ fosse a razão para omitirem a informaşāo ou então, realmente, o consumo seja menor. Sabe-se, entretanto, que, gegundo a tradição, os idosos tēm maior liberdade, respeitando-se, em geral, suas "extravagāncias". 8,44

Quardo se comparou a menção sobre bebidas alcoólicas entre os IAG e IDG, estes ültimos citaram-nas mais freqüuntermente o consumo de aguandente. No Japāo moderno esta restrição à bebida alcoólica é insignificante. Talvez, por estarem em um novo País, esses migrantes ajam neste sentido, mais naturalmen te, sem vigiläncia excessiva de conduta. 
CARDOSO $^{5}$, em sua palestra de abertura na III Conrnção Panamericana, "NIKKEI" (1956), focaliza a identificaçäo só cio-cultural dos "nikkeis", dentro do contexto nacional, posicionando-se ao afirmar que esta identficação abrange a somatöria das duas culturas em sua dinâmica e não a destruição de . uma em benefício da outra. 


\section{CONCLUSOEES}

- Mesmo em populações com forte tradição cultural observam-se mudanças em seus hābitos alimentares. Circunstâncias ecolōgicas têm papel importante nessas alteraçöes.

- A comparação de "isseis" com seus descendentes "nikkeis" revelou um evidente enfraquecimento do fator cultural de origem no que diz respeito à alimentação que, entretanto, não foi abrangente a todos os tipos de alimentos. Embora manten do elevada freqüência do consumo de alimentos orientais, ob servou-se rápida ocidentalizaço da dieta dos $D$.

- A anālise de duas geraçōes consecutivas - IAG e D - nos dá idéia da velocidade de mudança nos hábitos alimentares, mes = mo quando estes hábitos ainda estejam influenciados por uma forte pressão cultural. 0 posicionamento dos IDG, nesta evo Iução, aproxima-os mais dos $D$ do que dos IAG, em razão de trazerem diversificaçōes alimentares já incorporadas no Japão de pós-Guerra.

- O aspecto cultural teve um papel relevante na permanência de alguns alimentos típicos japoneses, porēm, não resistiu à mu dança no preparo usual dos alimentos, onde a incorporação de novos condimentos e abandono dos tradicionais teve função de acelerar a aculturação alimentar em direção aos hābitos nacionais.

- Estudos desta natureza podem trazer contribuição ao planejamento de programas de suplementação alimentar e no prognóstị co da aceitação de novos produtos alimentícios. 


\section{REFERẼNCIAS BIBLIOGRĀFICAS}

1. AMERICAN INTERNATIONAL NUTRITION - Contributions of anthropology to the assessment of nutrition status. Feder. Proc., $37: 47-76,1978$.

2. ANGOVE, R. - Nutrition education for change. J. Human Nutr., $33: 65-9,1979$.

3. BURGESS, A. \& DEAN, R.F. A. - La malnutrición y los hábitos alimentarios. Washington, D.C., Organización Pănamericana de la Salud, 1963. (OPS-Publ. cient., 91).

4. CÂMARA DE COMERCIO E INDÚSTRIA JAPONESA NO BRASIL. O método japonês. São Paulo, ed. Ohno, 1985 .

5. CARDOSO. F.H.- Americanidade dos "nikkeis". In: ConVENçăo PANAMERICANA NIKKEI- Onikkei e sua americanidade.São Paulo, ed. Ohno, 1986./ Temas apresentados na III Conven çāo Panamericana nikkei/.

6. COMPANHIA DE ENTREPOSTOS E ARMAZENS GERAIS DE SÃO PAULO-Boletim informativo anual 1980. CEAGESP, 1981, Departa mento de Economia/ Serviço de Estatística. Säo Paulo. (Impresso).

7. CHRISTAKIS, G. - Nutritional assessment in health prograns. Part 1: methodology. Aner.J.Publ. H1th.E3 (supl.11): $11-7,1973$. 
8. CONVENÇÃO PANAMERICANA NIKKEI - O njkkei e sua americanidade. São Paulo, ed. Onno, $1986 . /$ Temas apresentados na III Convenção Panamericana nikkei/.

9. DeWALT, K.M.- Diet as adaptation: the search for nutritional strategies. Feder. Proc.40: 2606-10, 1981.

10. DICKINS, D. - Factors related to food preferences. J. Home Ecorom., 57:427-30, 1975 .

11. FOLEY, C. et al. - Attitudes and food habits-a review. J. Amer. Diet. Ass., 75, 13. $7,1979$.

12. FUNDAÇAOO INSTITUTO BRASILEIRO DE GEOGRAFIA E ESTATÍSTICA Indicadores sociais; Relatório 1979 . Rio de Janeiro, IBGE, 1979 .

13. FUNDAÇAO INSTITUTO BRASILEIRO DE GEOGRAFIA E ESTATISTICA Perfil estatistico de criangas e mães no Brasil:características sócio-demogräficos 1970-1977, Rio de Janeiro, IBGE/UNICEF, 1982 .

14. GALlAGHER, C.F. - Japan and the world food problen. Fieldstaff Reports, East Asia series, Japan, 12:1-17, 1975 .

15. GARINE, E.I. The socio-cultural aspects of nutrition. Ecol. Food Nutr., 1:143-63, 1972 .

16. GINDLER, E.M. - Some nonparametric statistical tests for quick evaluation of clinical data. Clin. Chem. 21 : $309-$ 14,1975 
17. GUSSOW, J.D. \& CONTENTO, I. - Nutrition education in a chan ging world. Wld Rev. Nutr. Diet., 44:1-56, Basel, Karger, 1984.

18. HAAS, J.D.\& HARRISON G.G. - Nutritional anthropology and biological adaptation. Amn. Rev. Anthropol., 6:69-101 1977.

19. HAENSZEL, W. Repont of the working group on studies of can cer and related diseases in migrant populations.' 'Int. J. Cancer, $4: 364-71,1969$.

20. HERTZLER, A.A. \& OWEN, C. - Culture, families, and the chan ge process - a system approach, J. Aner. diet. Ass., 84: $535-43,1984$.

21. IIDA, L. - Pequena e mẽdia empresa no Japão. São Paulo. SÃO PAULO, CNPq, 1984 .

22. INSTITUTO BRASILEIRO DE GEOGRAFIA E ESTATISTICA - EnCICIOpédia dos municipios brasileircs, Rio de Janeiro, v. 28 , 29,1957

23. INSULL, Ir., W. et al. - Diet and nutritional status of japanese. Amer. J. clin. Nutr., 21: 753-77, 1968,

24. ISHII, M. - Estudo de uma população de origem japonesa e de seus häbitos alimentares quanco integrada no sistema eco lógico de duas localidades de expansão cafeeira paulista. São Paulo, 1980/Dissertação de mestrado. Faculdade de Saú de Pública da USP/. 
25. JEROME N. W. E PELTO, G.H. - Integrating ethrografic research with nutrition studies. Feder. Proc., 40: 2601$5, .1981$.

26. JEROME N.W. et al. - Nutritional anthropology, contemporary approaches to diet and culture: In: SCHNETZ M. et al., Migration and nutrition Thailand. Ecol. Food Nutr.,15: $89-107,1984$.

27. JUDD, J. - Century old dietary Iaboos in 20 th century Japan. J. Amer. diet. Ass., 33:489-91, 1957 .

28. KAGAN, A. et al. - Dietary and other risk factors for stroke in hawaiian japanese men. Stroke, 16, 390-6, 1985.

29. KUNIYOSHI, C.\& PIRES, W. - Casarão do chä (Mogi das Cruzes). São Paulo, CONDEPHAAT, 1984.

30. MEAD, M. - El alimento y la familia. Buenos Aires, ed. Su damericana, 1951.

31. MEAD, M. - Food habits rosearch. Protlems in the 1960's. Publ. 1225. Washington, D.C. National Academy of Sciences, 1964. In: HERTZLER, A.A. \& OWEN, C. - Culture, families, and the change process $-a$ system approach. U. Amer. diet. Ass., 84:535-43, 1984 .

32. MINISTRY OF HEALTH AND WELFARE. Japanese government. Malnutrition and nutrition activities in Japan. Tokyo, 1956. 
33. MINISTRY OF HEALTH AND WELFARE - Bureau of Public Health. Nutrition Section. National nutrition survey. Nutrition in Japan. Tokyo, 1964.

34. MINISTERIO DE SAŨDE E BEM ESTAR - Departamento de Saúde Pú blica. Resultados do inquérito racional de nutrição (1972-1973). Toquio, $1977 /$ trasliterado do original em japonês/.

35. MUIR, $c$. In: Report of the working group on studies of can cer and related diseases in migrant populations. Inter. J. Cancer, $4: 364-71,1969$.

36. NATIONAL RESEARCH COUNCII - The problem of changing food habits; Report of the conmittee on food habits, 19411943, Washington, D.C., National Academy of Sciences, 1943 (Bull, 108).

37. NATIONAL RESEARCH COUNCIL - Manual for the committee on food habits. Washington, D.C., National Academy of Scien ces, 1945. (Bu11. 111).

38. NOGUEIRA, A.R.- A imigragão japonesa para a lavoura ca feeira paulista $(1908-1922)$. São Paulo, Instituto de Es tudos Brasileiros, ed. USP, 1973.

39. NOGUEIRA, A.R.- Imigraçöo japonesa na histöria contemporânea do Brasil. São Paulo, Centro de Estudos Nipo-Brá sileiros, ed. Ohno, 1983. 
40. OISO, T. \& SUZUE, R.- Tonic of nutrition in Japan. Amer. J. clin. Nutr., 23: 1096-8, 1970 .

41. OISO, T.- Changing food patterns in Japan. Food \& Nutr. Research Ass. Tokyo, 1980. (mimeo).

42. REID, D.D. - The future of migrant studies. Israel J. med. Sci., 7:1592-6, 1971 .

43. REID, D.D. - International studies in epodemiology. Amer. J. Epidem , 102:469-76, 1975 .

44. SAITO H. \& MAEYAMA, T. - Assimilação e integração dos japoneses no Brasil, São Paulo, ed. USP, 1973.

45. SIEGEL,S. - Estatística não-paramétrica para as ciências do comportamento. São Paulo, ed. Mcgraw-Hill do Brasil, 1975 .

46. TILLOLSON, J. et al - Epidemiology of coronary heart disease and stroke in japanese men living in Japan, Hawaii and Califórnia: methodology for comparison of diet. Amer. J. clin. Nutr., 26:177-84, 1973.

47. TODHUNTER, E.N. - Food habits, food faddism and nutrition. In: RECHCIGL, M., ed. Food nutrition and health; world review of nutrition and dietetic. Basel, Karger, 1973. v. $16, \mathrm{P} \cdot 286-317$. 
TREQUENCIA, DE CONSUMO PAMILIA.P. DE ALIMENTOS DCIDENTAIS E COMUNS AOS DOIS

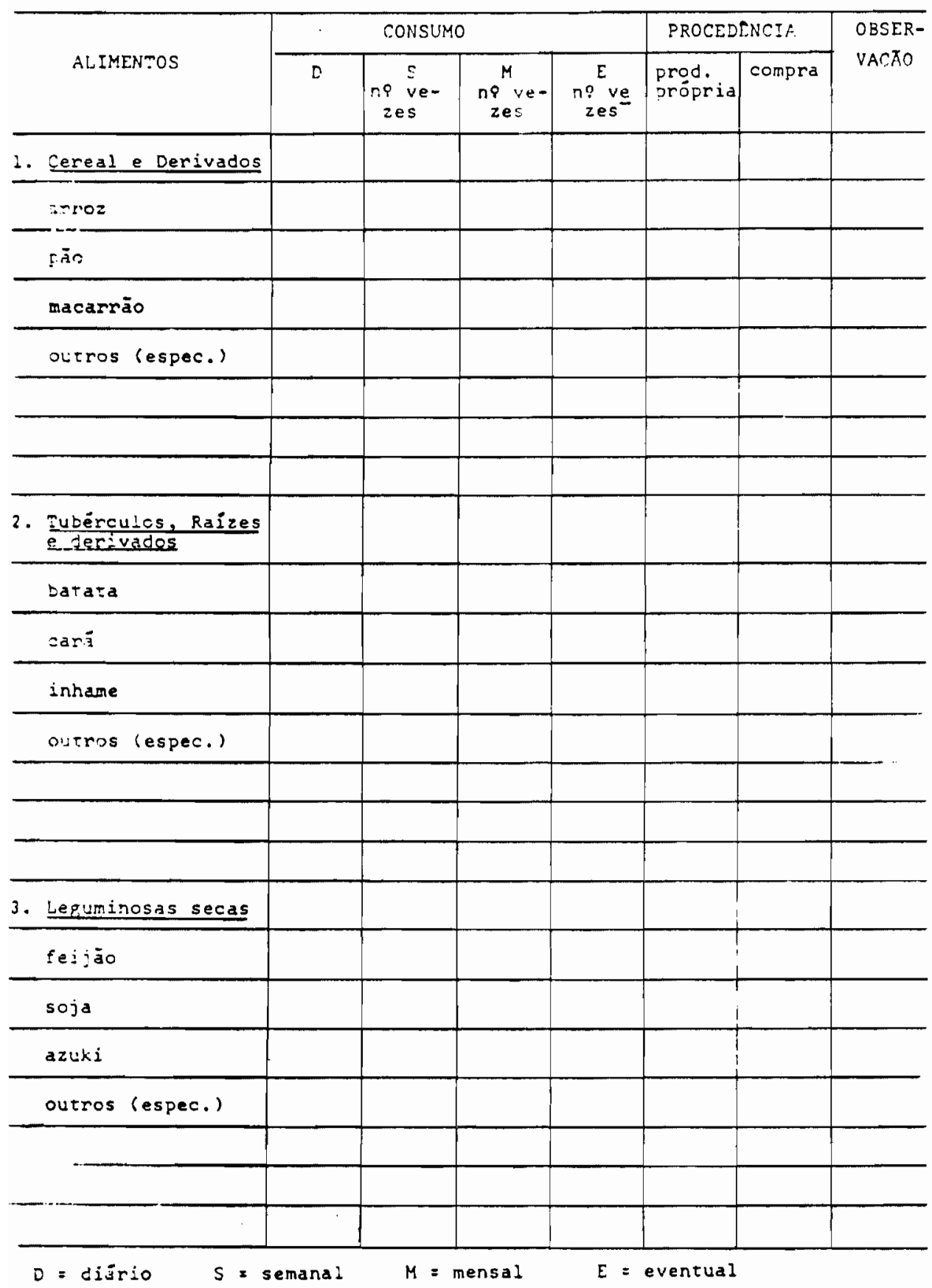




\begin{tabular}{|c|c|c|c|c|c|c|c|}
\hline \multirow{2}{*}{ ALIMENTOS } & \multicolumn{3}{|c|}{ con!susn } & \multirow{2}{*}{ 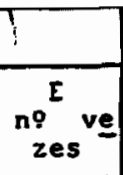 } & \multicolumn{2}{|c|}{ PROCLDENCIA } & \multirow{2}{*}{$\underset{\text { ÇAOO }}{\text { OBSERVA }}$} \\
\hline & D & $\operatorname{mi}_{\text {zes }}^{\mathrm{S}} \mathrm{ve}$ & $\underset{\text { zes }}{M}$ ve & & $\begin{array}{c}\text { prod. } \\
\text { propria } \\
\end{array}$ & compra & \\
\hline \multicolumn{8}{|l|}{ 4. Vexetais } \\
\hline \multicolumn{8}{|l|}{ aböbora } \\
\hline \multicolumn{8}{|l|}{ aboininha } \\
\hline \multicolumn{8}{|l|}{ aceiga } \\
\hline \multicolumn{8}{|l|}{ agriāo } \\
\hline \multicolumn{8}{|l|}{ alface } \\
\hline \multicolumn{8}{|l|}{ berinjela } \\
\hline \multicolumn{8}{|l|}{ beterrabe } \\
\hline \multicolumn{8}{|l|}{ brócoli } \\
\hline \multicolumn{8}{|l|}{ cenoura } \\
\hline \multicolumn{8}{|l|}{ cebolinha } \\
\hline \multicolumn{8}{|l|}{ chicória } \\
\hline \multicolumn{8}{|l|}{ couve } \\
\hline \multicolumn{8}{|l|}{ chucinu } \\
\hline \multicolumn{8}{|l|}{ couve-flor } \\
\hline \multicolumn{8}{|l|}{ gobo } \\
\hline \multicolumn{8}{|l|}{ moyashi } \\
\hline \multicolumn{8}{|l|}{ nabo } \\
\hline \multicolumn{8}{|l|}{ pepino } \\
\hline \multicolumn{8}{|l|}{ pimentioo } \\
\hline \multicolumn{8}{|l|}{ repolno } \\
\hline \multicolumn{8}{|l|}{ tomate } \\
\hline \multicolumn{8}{|l|}{ vagem } \\
\hline & & & & & & & \\
\hline & & & & & & & \\
\hline & & & & & & & \\
\hline & & & & & & & \\
\hline & & - & & & & & \\
\hline & & & & & & & \\
\hline & & & & & & & \\
\hline & & & & & & & \\
\hline & & & & & & & \\
\hline & & & & & - & & \\
\hline
\end{tabular}


$-05-$

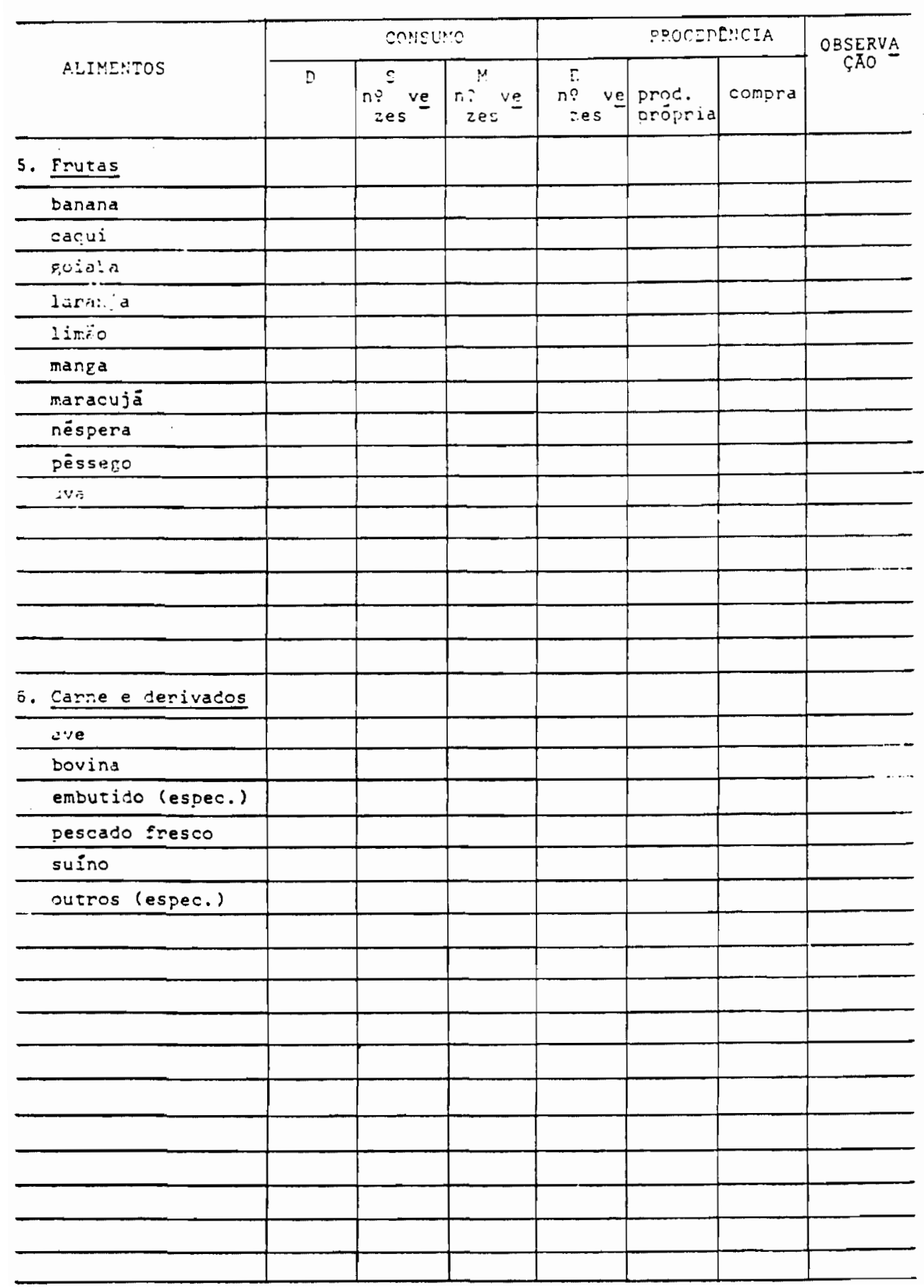


$-05-$

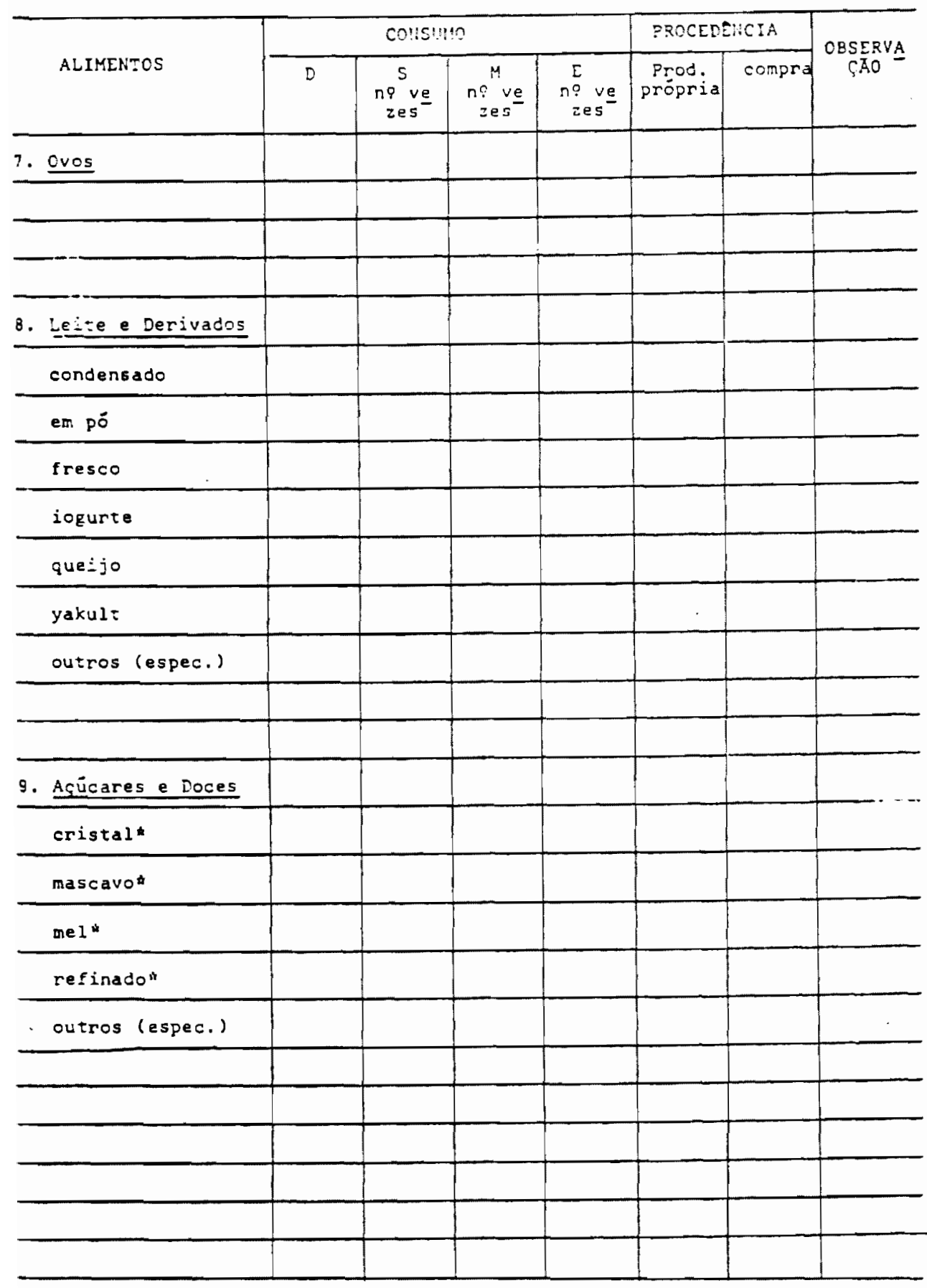

- anotar o consumo mensal médio 
$-07-$

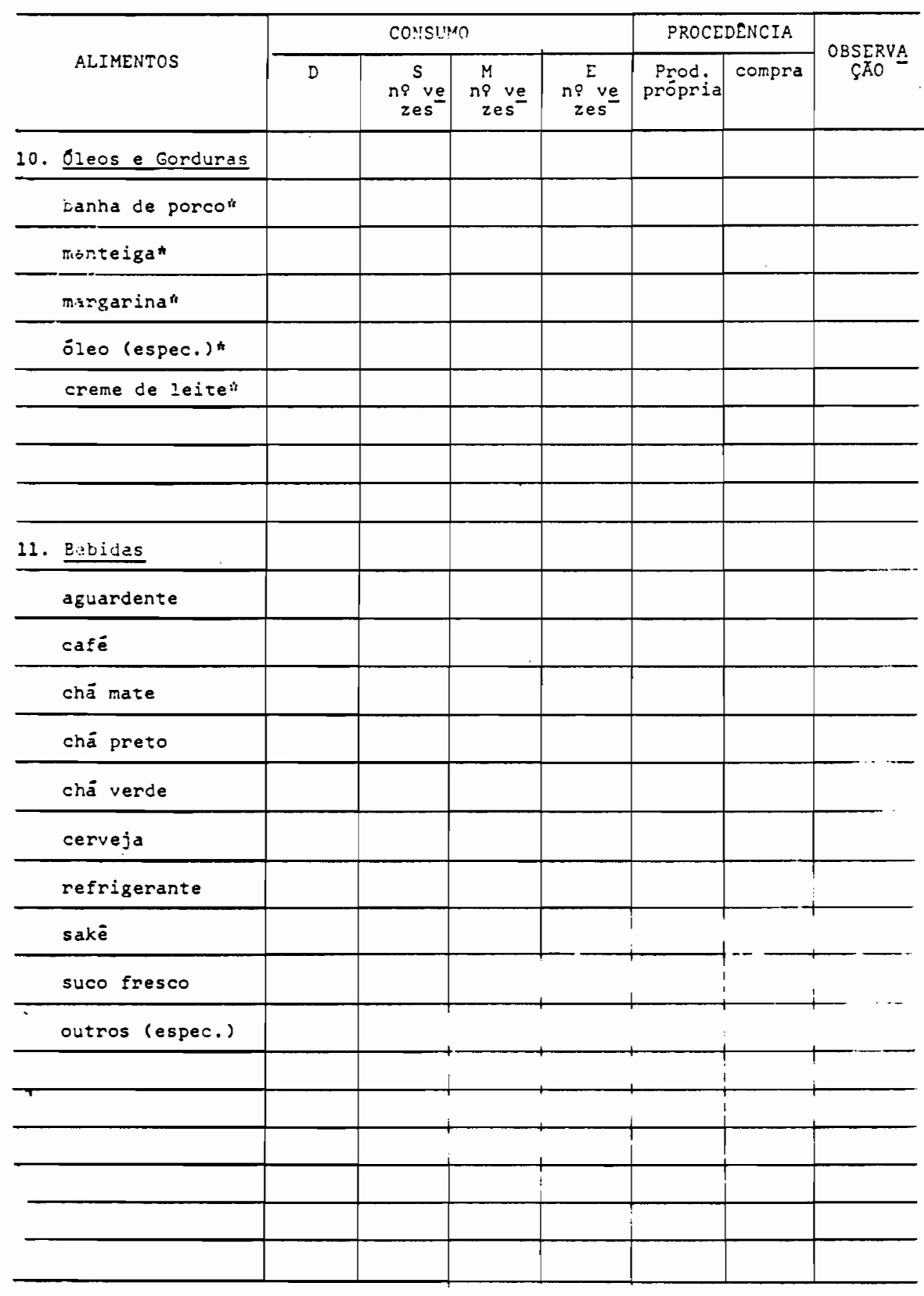

* anotar consumo médio mensal 


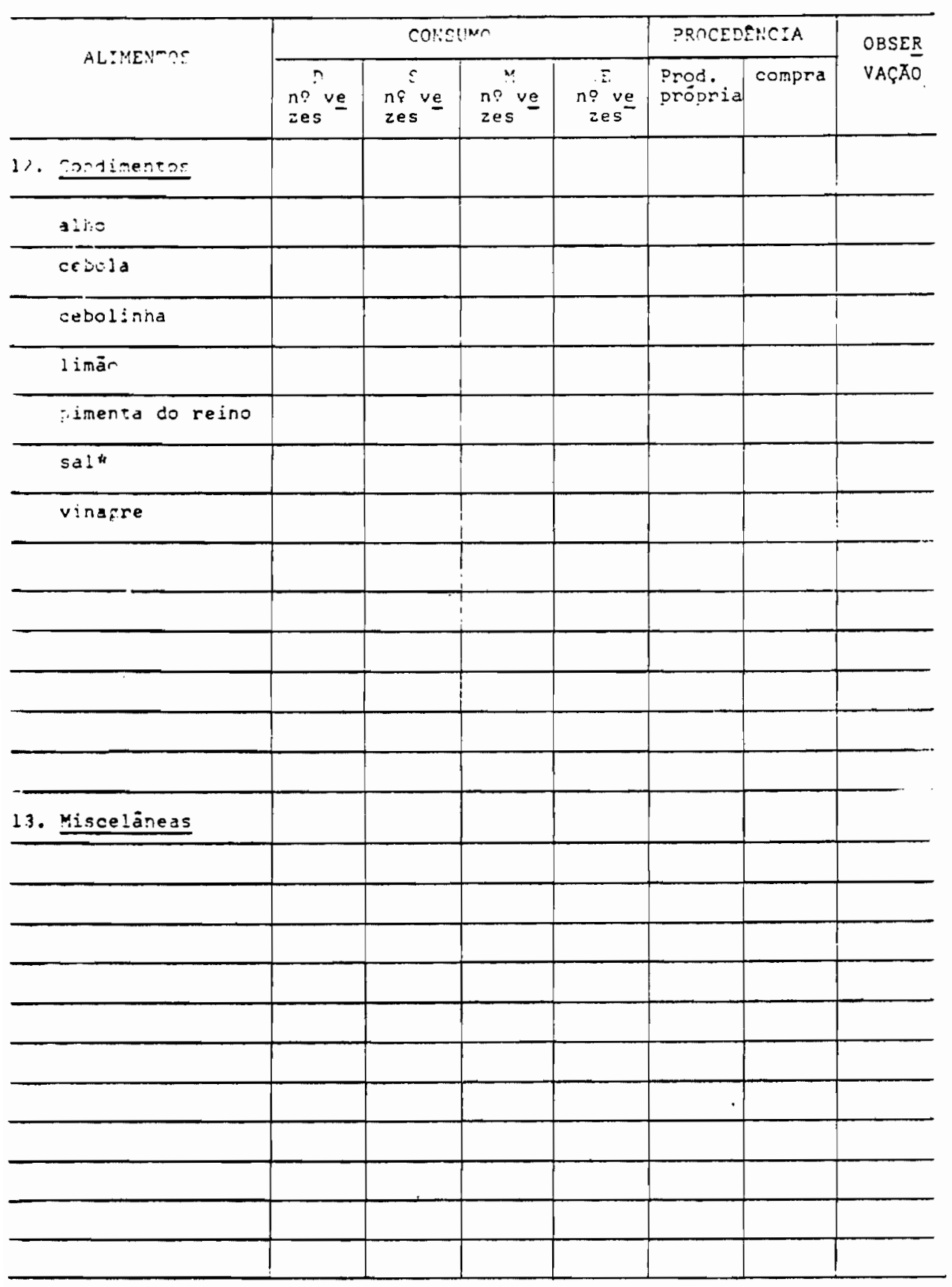

* anotar consumo mensal médio 
AI,TMENTOS RRIETTAIS

\begin{tabular}{|c|c|c|c|c|c|c|c|}
\hline \multirow[b]{2}{*}{ ALIMENTOS } & \multicolumn{4}{|c|}{ CONSUNOO } & \multicolumn{2}{|c|}{ PROCEDENCIA } & \multirow{2}{*}{$\begin{array}{l}\text { OBSER } \\
\text { VAÇAD }\end{array}$} \\
\hline & $\begin{array}{l}D \\
\text { n? ve } \\
\text { zes }\end{array}$ & $\begin{array}{l}\text { S } \\
\text { ne ve ve } \\
\text { zes }\end{array}$ & $\begin{array}{l}\text { Me ve } \\
\text { zes }\end{array}$ & $\begin{array}{l}\tilde{E} \\
n ? \text { ves } \\
\text { zes }\end{array}$ & $\begin{array}{l}\text { Frod. } \\
\text { proppia }\end{array}$ & compra & \\
\hline \multicolumn{8}{|l|}{ 1. Sota } \\
\hline \multicolumn{8}{|l|}{ aguê } \\
\hline \multicolumn{8}{|l|}{ missol } \\
\hline \multicolumn{8}{|l|}{ toru } \\
\hline \multicolumn{8}{|l|}{ shoyu } \\
\hline \multicolumn{8}{|l|}{ 2. Deixes } \\
\hline \multicolumn{8}{|l|}{ dashico } \\
\hline \multicolumn{8}{|l|}{ kamaboco } \\
\hline \multicolumn{8}{|l|}{ mesashi } \\
\hline \multicolumn{8}{|l|}{ tikua } \\
\hline & & & & & & & \\
\hline & & & & & & & \\
\hline & & & & & & & \\
\hline \multicolumn{8}{|l|}{ 3. Algas } \\
\hline \multicolumn{8}{|l|}{ kombu } \\
\hline \multicolumn{8}{|l|}{ nori } \\
\hline \multicolumn{8}{|l|}{ wakame } \\
\hline \multicolumn{8}{|l|}{ - } \\
\hline & & & & & & & \\
\hline & & & & & & & \\
\hline & & & & & & & \\
\hline & & & & & & & \\
\hline & & & & & & & \\
\hline & & & & & & & \\
\hline
\end{tabular}

* Anotar consumo médio mensa? 


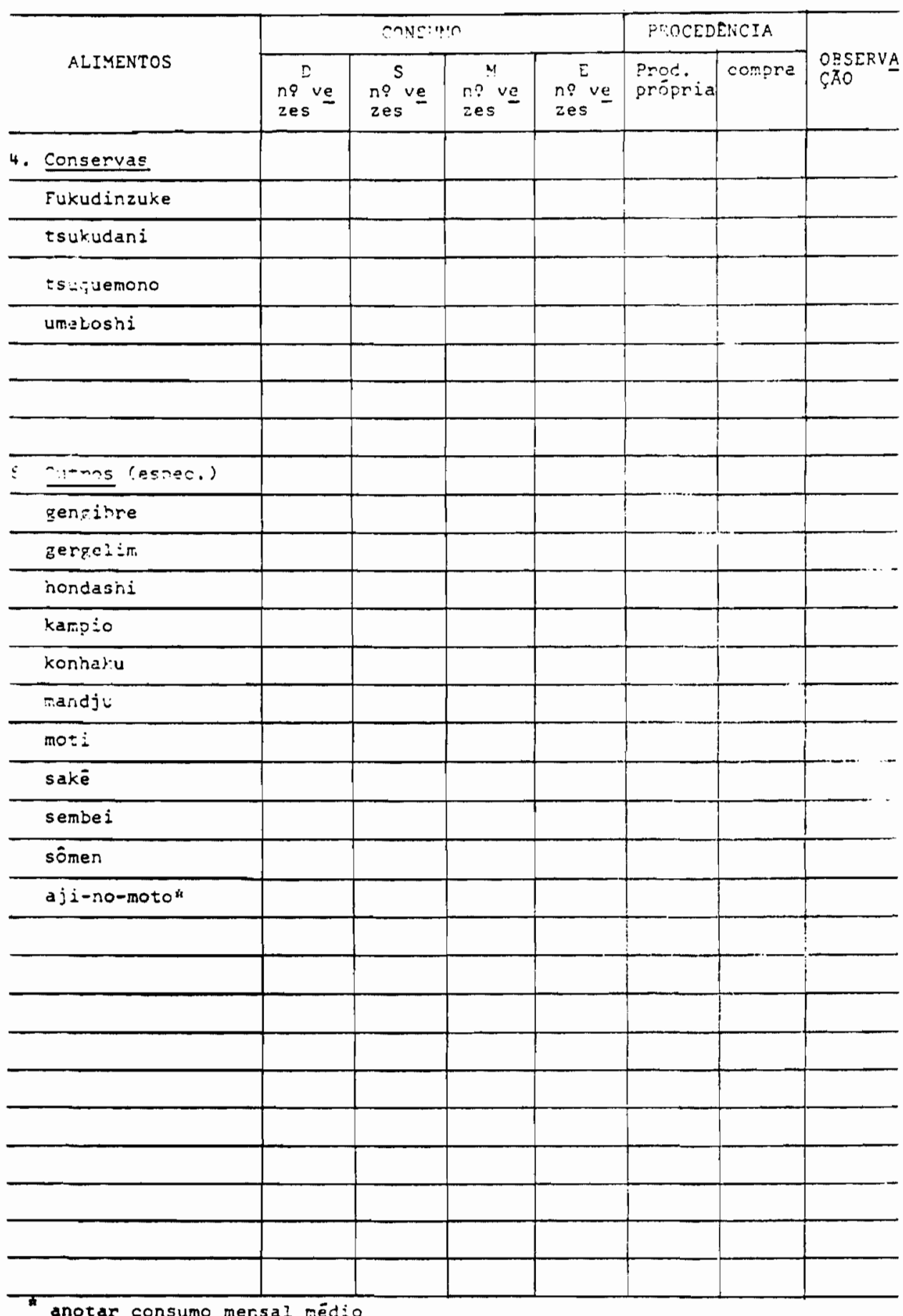


$-11-$

INQUERITO ALIMENTAR RECORDATORIO DE 24 HORAS E PESAGEM

DESJEJUM:

Nome da preparação

Alimentos

Quantidade ( $g$ ) 
ENTRE AS REFEICOES:

Horário

$n$ ? orden dos ausente:

RESPONSABILIDADE DO PREPARO:

Nümero de refeiçōes ao dia:

Data: / / 1981

Dia da semana:

OBSERVAÇOES: 
1. Area da Propriedade Total alqueire(s)

2. Area utilizada para produção alqueire(s) Tipo de produção

3. Condição de Posse da Propriedade

$\begin{array}{ll}\text { Pröpria e paga ( ) } & \text { Própria em aquisição ( ) } \\ \text { Parceiro ( ) } & \text { Meeiro ( ) }\end{array}$

Outro (especificar)

Ser declaração( )

4. Tipo de Construção da Moradia

Tijolo () () Outro (especificar)

5. Número total de cômodos:

OBS: Todos os compartimentos integrantes do domicilio sepa rados por paredes, inclusive os existentes na parte externa do prēdio, desde que constituirem parte inte grande do domicilio, com exceça de corredores, alpen dres, varandas, garagens, depósitos e outros comparti mentos para fins não residenciais.

6. Número de Dormitörios:

OBS: Além dos quartos, considera-se as demais dependèncias que estiverem em caräter permanente servindo de dormi tório. Excluir os quartos que habitualmente não esti verem servindo de dormitório. 
7. Tipo, nümero e localização do sanitärio e esgoto

Dentro de casa: NQ

sem descarga hïdrica Fora de casa: No

Tipo de esgoto:

com descarga hidrica

Dentro de casa: No

Fora de casa: No

Tipo de esgoto

3. Abastecimento de ägua de consumo humano.

- Poşo ()

convencional ()

freatico ()

perfurado ( )

Revestimento interno

$\sin ($ )

nāo ( )

Bomba

$\sin ()$

não ()

localização do poço en relação a fossa:

amontante $($ )

ajuizante*()

Distäncia metros

- Nascente ()

- Outro (especificar)

Tratamento da água de beber: $\operatorname{sim}()$ Não ()

Se, SIM:

Filtra ( )

Ferve ()

Clora ( )

outro (especificar)

* amontante - acima da fossa

ajuizante-- abaixo da fossa

9. Disposiçāo do lixo:

Queimado até $\circ 29$ dia ()

Jogado a céu aberto (')

Enterrado（） Distāncia: metros da casa

Outro (especificar): 
10. Dados de Bens Materiais e de Lazer

Telefone ()

Rãdio ( )

Televisão: Preta e Branca () Colorida ()

Video Cassete ( )

Apare tho de Som ( )

Geladeira ( )

Freezer ( )

Liquidificador ( )

Panela Elëtrica para Arroz - Denkigama ()

Máquina de lavar roupa ( )

Aspirador ( )

Batedeira ( )

Enceradeira ()

Jornal (especificar)

$\begin{array}{ll}\text { Aquisisăo } & \\ \text { regular espordico }\end{array}$

$\left[\begin{array}{l}-2, \\ \hline\end{array}\right.$

( ) 1

( ) :

( ) (

\begin{tabular}{lcc}
\hline Revista (especificar) & regulấluisiçăesporádico \\
\hline & $($ ) & $($ ) \\
\hline & $()$, & $()$, \\
\hline
\end{tabular}

11. Meios de Transjorte

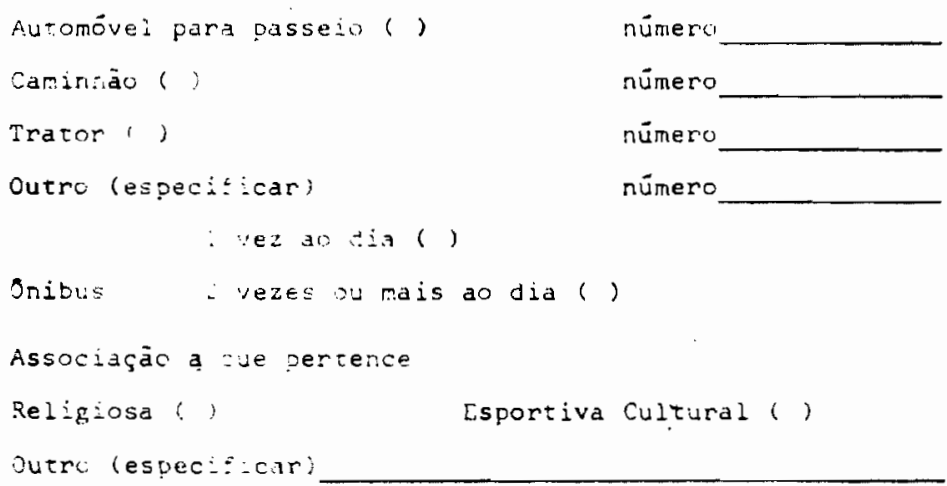


ANEXO 3

CONCE I TUAÇÃO

As conceituações, abaixo apresentadas, são as utili zadas pelo FIBGE e que foram aplicadas no presente estudo. população residente- A população residente é constituída pelas pessoas moradoras no domicílio, mesmo que ausentes na data da Pesquisa.

Situaçāo no domicílio- Segundo a localização do domicílio, a situaçāo pode ser urbana ou rural, definida por lei muni cipal. Como situação urbana consideram-se as äreas corres pondentes às Cidades (sedes municipais) ou às Vilas (sedes distritais). A situação rural abrange toda a ârea situada fora desses limites.

Populaçāo urbana e rural- Considerou-se como População urbana a pesquisada nas cidades ou vilas, e como População ru ral a pesquisada fora dos limites das cidades ou vilas.

Tipo de construçāo- Classificaram-se os Domicílios particu lares, segundo o tipo de construção, em: Permanentes, assim considerados os construídos para fins residenciais; e Improvisados, os que não atendessem à referida condição, embora servissem de moradia na data de referencia, tais como lojas, salas, prëdios em construção, embarcações, carroças, vagões, tendas, barracas, grutas, pätios, etc.

Com base no material empregado nas paredes, piso e cobertura, os Domicílios particulares permanentes foram classificados em Duräveis e Rủsticos. Consideravam-se Durā 
vels os domicflios locallzados em prédios em cuja construçäo predominassem paredes de alvenaria ou de madeira preparada ou, ainda, de outros materiais, exclusive taipa não revesti'da ou palha, mas com piso de madeira, cimento ou cerámica e cobertura de laje, telha de barro ou cimento-amianto.

Os demais dados referem-se somente a Domicílios particulares permanentes.

Condição de ocupação- Foram consideradas as seguintes Condiçōes de ocupação: Prōprio- Já acabou de pagar (quando a famí lia residia en domicílio de sua propriedade, totalmente pago, independentemente de o terreno ser ou nāo de sua proprie dade); Próprio- Não acabou de pagar (quando a família residia em domicílio de sua propriedade, mas ainda não tivesse pago o valor total da aquisição, independentemente de o terreno ser ou nāo de sua propriedade); alugado; Cedido(inclusi ve os domicílios de trabalhadores na agropecuária residentes nas fazendas onde exercessem sua ocupaçāo, mesmo que tivessem residindo em domicílio que não se enquadrasse em nenhu ma das categorias anteriormente mencionadas". Em nossa pesqui sa transpōs esta conceituação no sentido do proprietário de terra: Próprio e pago; próprio em aquisiçāo;meeiro ou parceiro, o cedido àquele que explorava a terra sem pagamento em dinheiro ou em espécies, e outra condição- quando se não enquadrasse em nenhuma das categorias definidas.

Abastecimento d'água- Investigou-se a forma de abastecimento d'água dos domicílios, de acordo com as seguintes condiçōes estabelecidas nos instrumentos de coleta: Rede geral, com ou sem canalização interna; Poço ou nascente, com ou sem canali zação interna; Poço ou nascente, com ou sem canalização interna; e Outra forma, assim considerados os abastecimentos 
oriundos de fontes püblicas, poços ou torneiras localizadas fora do domicílio,

Instalações sanitārias- Pesquisou-se a existência de instala ções sanitärias que foram classificadas, por tipo de escoadouro, em: Rede geral; Fossa séptica; Fossa rudimentar; e Outro escoadouro, quando fossem usados, diretamente, como lagos: e rios.

Foram considerados como nāo tendo instalações sani tārias os domicílios cujos moradores utilizassem instalações comuns a mais de um domicílio.

Iluminação elētrica- Formulou-se indagação sobre a existência de iluminação elétrica nos domicílios, independentemente de ser fornecida através de uma rede geral.

Total de cômodos- Foram computados todos os compartimentos integrantes do domicílio separados por paredes, inclusive os existentes na parte externa do prédio desde que se constituissem parte integrante do domicílio, com exceção de corredores. alpendres, varandas, garagens, depósitos e outros compartimentos para fins não residenciais (banheiros).

Dormitórios- Além dos quartos, foram consideradas todas as demais dependências que estivessem, em carāter permanente, servindo de dormitório. Foram excluídos os quartos que habi tualmente não servissem de dormitório.

Densidade domiciliar- Numerosas pesquisas indicam ser a den sidade domiciliar um determinante importante na saúde física e mental dos moradores de uma unidade domiciliar.

Um outro indicador de densidade domiciliar é o nümero de pessoas por cômodo habitāvel, o banheiro e a cozinha 
: ndo excluídos do total de cômodos habitáveís. Atê 1,5 pes soés por cômodo habitävel è normalmente considerado uma dens..ciade "aceitável". 


\section{ANEXO 4}

\begin{tabular}{|c|c|c|c|c|c|c|c|c|c|c|}
\hline \multirow{3}{*}{$\begin{array}{l}\text { preponder.da- } \\
\text { ientats (A1 men } \\
\text { pientais) }\end{array}$} & \multicolumn{5}{|l|}{ A } & \\
\hline & \multicolumn{5}{|c|}{$\begin{array}{l}\text { Distribuiçāo de número de frequência dos ali- } \\
\text { mentos p. ortentais en diäria (D); semanal } \\
\begin{array}{llll}\text { (S): mensal (M) e eventual } & \text { (E), segundo gru } \\
\text { po familiar IAG. D. IDG } & & \end{array}\end{array}$} & \multicolumn{5}{|c|}{ 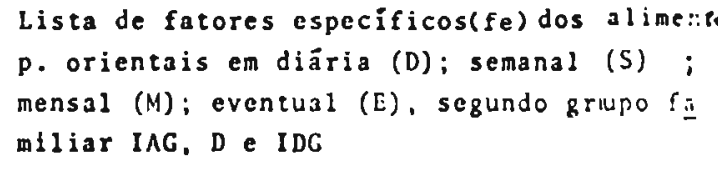 } \\
\hline & $\begin{array}{l}\text { Grupo } \\
\text { familiar }\end{array}$ & D & $\mathbf{s}$ & $M$ & $E$ & D & $\mathbf{S}$ & $\mathbf{M}$ & $\vdots$ & $\mathrm{E}$ \\
\hline \multirow{15}{*}{ in } & IAC & 0 & 4 & 11 & 12 & 0 & 1,8 & 1.6 & 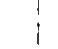 & 3.1 \\
\hline & D & 0 & 3 & 16 & 14 & 0 & 1.6 & 1,6 & i & 3.1 \\
\hline & I DG & 0 & 49 & 28 & 14 & 0 & 2,3 & 1,8 & $i$ & 3.1 \\
\hline & IAG & 29 & 1 & 0 & 1 & 1,0 & 4,5 & 0 & : & 8.0 \\
\hline & D & 36 & 1 & 0 & 1 & 1,0 & 4,0 & 0 & $!$ & 6.0 \\
\hline & IDG & 92 & 5 & 1. & 0 & 1,0 & 2,2 & 3,0 & I & 0 \\
\hline & IAG & 31 & 0 & 0 & 0 & 1,0 & 0 & 0 & : & 0 \\
\hline & D & 37 & 1 & 0 & 0 & 1.0 & 5.0 & 0 & $\vdots$ & 0 \\
\hline & IDG & 98 & 0 & 0 & 0 & 1.0 & 0 & 0 & 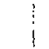 & 0 \\
\hline & IAG & 0 & 1 & 11 & 1 & 0 & 1.0 & 1.6 & $!$ & 3.8 \\
\hline & D & 0 & 1 & 13 & 18 & 0 & 2,0 & 1.4 & $!$ & 2.4 \\
\hline & IDG & 0 & 5 & 52 & 24 & 0 & 1.0 & 1.4 & 1 & 3.7 \\
\hline & IAC & 0 & 5 & 2 & 7 & 0 & 1,8 & 2,0 & & 3.6 \\
\hline & D & 0 & 6 & 13 & 6 & 0 & 1,3 & 1,4 & & 3.5 \\
\hline & IDC & 0 & 25 & 31 & 11 & 0 & 1,5 & 1,5 & & 3.3 \\
\hline \multirow[t]{3}{*}{ m } & IAG & 17 & 11 & 1 & 0 & 1,0 & 2,4 & 2,0 & & 0 \\
\hline & D & 12 & 18 & 3 & 0 & 1,0 & 2.7 & 1.7 & & 0 \\
\hline & IDG & 57 & 30 & 10 & 1 & 1,0 & 3,3 & 2,0 & & 10.0 \\
\hline \multirow[t]{3}{*}{ latal - outros } & IAG & 5 & 0 & 0 & 0 & 1,0 & 0 & 0 & & 0 \\
\hline & D & 0 & 0 & 0 & 0 & 0 & 0 & 0 & 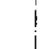 & 0 \\
\hline & IDG & 14 & 1 & 0 & 0 & 1.0 & 2,0 & 0 & & r \\
\hline \multirow[t]{9}{*}{ in } & IAG & 8 & 2 & 4 & 0 & 1,0 & 1.5 & 1,5 & & 0 \\
\hline & D & 5 & 3 & 2 & 5 & 1.0 & 2,0 & 1.0 & & 4.1 \\
\hline & IDG & 53 & 15 & 3 & 0 & 1.0 & 1.9 & 1.0 & & 0 \\
\hline & IAG & 0 & 3 & 20 & 4 & 0 & 1,0 & $.3,0$ & & 4.5 \\
\hline & D & 0 & 2 & 23 & 7 & 0 & 1,5 & 2,5 & & 3.2 \\
\hline & IDG & 0 & 25 & 42 & 5 & 0 & 1,1 & 3,0 & 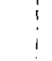 & 1.0 \\
\hline & IAG & 5 & 9 & 2 & 4 & 1.0 & 3,3 & 1,5 & i & 3.0 \\
\hline & D & 7 & 10 & 3 & 2 & 1.0 & 2,9 & 1,3 & & $\therefore 0$ \\
\hline & IDG & 9 & 2 & 0 & 0 & 1,0 & 2,0 & 0 & & .0 \\
\hline \multirow[t]{3}{*}{ atule } & IAC & 6 & . 6 & 5 & 5 & 1,0 & 2,0 & 1.2 & 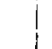 & 3.5 \\
\hline & D & 6 & 8 & 9 & 8 & 1,0 & 2.1 & 1.7 & & 2.6 \\
\hline & IDG & 13 & 20 & 25 & 13 & 1.0 & 1.9 & 1.5 & $i$ & 2.9 \\
\hline \multirow[t]{3}{*}{ 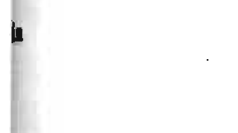 } & IAG & 1 & 8 & 7 & 3 & 1,0 & 1.5 & 1.7 & & 3.3 \\
\hline & D & 0 & 4 & 7 & 11 & 0 & 2.0 & 1.6 & & 2,9 \\
\hline & IDG & 2 & 37 & 28 & 16 & 1,0 & 1.9 & 1.7 & & 3,7 \\
\hline
\end{tabular}




\begin{tabular}{|c|c|c|c|c|c|c|c|c|c|}
\hline \multirow{2}{*}{$\begin{array}{l}\text { preponderadinen- } \\
\text { wis (Alimerics p. } \\
\text { a) }\end{array}$} & \multicolumn{5}{|c|}{ 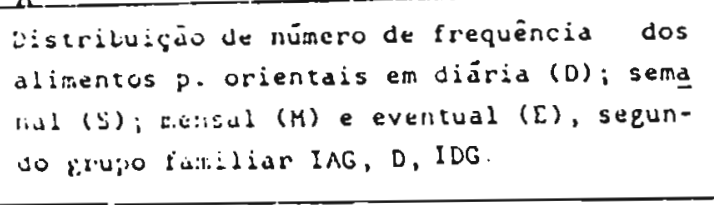 } & \multicolumn{4}{|c|}{ 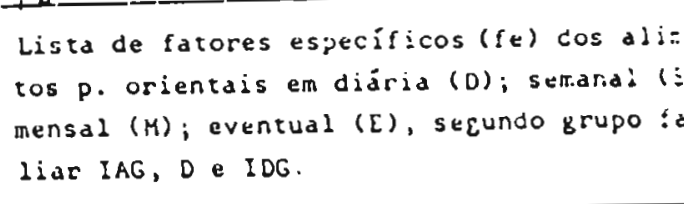 } \\
\hline & $\begin{array}{l}\text { Erupo } \\
\text { faxiliar }\end{array}$ & 0 & 5 & $M$ & E & ${ }^{D}$. & $\mathrm{s}$ & $M$ & $\Xi$ \\
\hline \multirow{48}{*}{ foja } & ! ici & 4 & 14 & 7 & 2 & 2,0 & 1,8 & 1,8 & $\therefore$. \\
\hline & $\because$ & 2 & 14 & 12 & 5 & 2,0 & 1,5 & 1,3 & 3,3 \\
\hline & $: 25$ & 7 & 54 & 22 & 6 & 2,0 & 1,9 & 1,8 & $3,:$ \\
\hline & O & 6 & 7 & 1 & 0 & 1,0 & 1,6 & 1,0 & 3 \\
\hline & 2 & 3 & 6 & 6 & 3 & 1,0 & 1,8 & 1,5 & 1.7 \\
\hline & 100 & 24 & 16 & 11 & 2 & 1,0 & 2,8 & 1,4 & 3. \\
\hline & $I A C$ & 0 & 16 & 8 & 2 & 0 & 2,2 & 1,8 & 2 \\
\hline & 0 & 0 & 16 & 11 & 6 & 0 & 1,8 & 1,9 & $j$, \\
\hline & $1 x$ & 0 & 45 & 35 & 9 & 0 & 2,1 & 1.8 & 4. \\
\hline & $i: S$ & $c$ & 3 & 9 & 16 & 0 & 1,0 & 1,3 & 2,8 \\
\hline & $D$ & 0 & 3 & 9 & 15 & 0 & 1,0 & 1,8 & 3. \\
\hline & $1 \omega 0$ & 0 & 6 & 8 & 4 & 0 & 1,2 & 1,7 & 2, \\
\hline & :AC & 0 & 2 & 6 & 14 & 0 & 2,0 & 2,0 & 4. \\
\hline & 2 & 0 & 3 & 5 & 19 & 0 & 1,3 & $1, \epsilon$ & 3,7 \\
\hline & Ixs & 0 & 1 & 34 & 51 & 0 & 1,0 & 1,2 & $3,=$ \\
\hline & IAG & 0 & 0 & 2 & 2 & 0 & 0 & 1,0 & 2, \\
\hline & $D$ & 0 & 0 & 1 & 0 & 0 & 0 & 1,0 & \\
\hline & $I D C$ & 0 & 0 & 3 & 3 & 0 & 0 & 1,3 & 3, \\
\hline & Iss & 0 & 1 & 8 & 16 & 0 & 1,0 & 1,4 & j, \\
\hline & 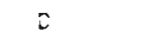 & 0 & 1 & 6 & 15 & 0 & 1,0 & 1,3 & 3, \\
\hline & $\therefore 8$ & 0 & 2 & 13 & 8 & 0 & 1,5 & 1,7 & 4. \\
\hline & $\therefore$ & 0 & 2 & 16 & 10 & 0 & 1,0 & 1,4 & 4. \\
\hline & $:$ & 0 & 8 & 17 & 10 & 0 & 1,0 & 1,5 & 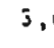 \\
\hline & $1 \approx c$ & c & 30 & 53 & 12 & 0 & 1,5 & 1,6 & 4, \\
\hline & $: A G$ & 0 & 0 & 0 & 0 & 0 & 0 & 0 & \\
\hline & 2 & 0 & 1 & 1 & 1 & 0 & 1,0 & 1,0 & 3. \\
\hline & !cs & 2 & 1 & 0 & 0 & 1,0 & 2,0 & 0 & \\
\hline & 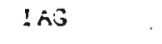 & 0 & 5 & 11 & 11 & 0 & 1,0 & 2,4 & 3, \\
\hline & 0 & 0 & 6 & 15 & 13 & 0 & 1,0 & 1,5 & 3 , \\
\hline & I DC & 0 & 25 & 48 & 14 & 0 & 1,2 & 1,7 & 3. \\
\hline & I AG & 2 & 25 & 6 & 4 & 1,0 & 2,0 & 1,8 & 5, \\
\hline & $D$ & 2 & 14 & 10 & 6 & 1,0 & 2,1 & 2,0 & 4, \\
\hline & ! IX & 4 & 56 & 20 & 2 & 1,0 & 2,2 & 2,3 & $\overline{0}$ \\
\hline & $\operatorname{lAC}$ & 0 & 6 & 4 & 9 & 0 & 1,3 & 1,5 & 2, \\
\hline & D & 0 & 4 & 5 & 8 & 0 & 1,2 & 1,0 & 2, \\
\hline & Cu & 0 & 1 & 7 & 0 & 0 & 3,0 & 1,5 & \\
\hline & $I A G$ & 0 & 4 & 2 & 4 & 0 & 1,5 & 2,0 & 4, \\
\hline & 5 & 0 & 0 & 5 & 4 & 0 & 0 & 1,4 & 2, \\
\hline & I DG & 1 & 19 & 7 & 7 & 1,0 & 1.7 & 2,3 & 3 \\
\hline & $I A G$ & 14 & 26 & 1 & 0 & 1,0 & 2,8 & 1,5 & \\
\hline & $\nu$ & 16 & 18 & 4 & 0 & 1,0 & 2,7 & 1,5 & \\
\hline & $I J G$ & 64 & 33 & 0 & 0 & 1,0 & 3,2 & 0 & \\
\hline & InG & 0 & 4 & 6 & 20 & 0 & 1,0 & 1,3 & 3, \\
\hline & D & 0 & 4 & 12 & 17 & 0 & 1,0 & 1,8 & 2, \\
\hline & 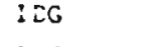 & 0 & 10 & 41 & 43 & 0 & 1,1 & 1,5 & 3, \\
\hline & ت:به 1 & 0 & 3 & 3 & 1 & 0 & 1,3 & 2,3 & s. \\
\hline & i: & 0 & 4 & 4 & 5 & 0 & 1,2 & 2,2 & 2, \\
\hline & : wi & 0 & 28 & 11 & 3 & 0 & 1,4 & 1,2 & 2, \\
\hline
\end{tabular}


miso...

ppreponderada- Distribuigáo de nümero de frequéncia dos mulals alimencos p. oriontais em diaria (U): semanal Hip. orientais). (S): aensil (M) E evencual (E). segundo grupo fomiliar ldi, I), IDG l.ista de fatores especificos(fe)dos aliment oriencais em diária (D): semanal (S): mensit (H): oventual (E), segundo grupo ramilias $A C, D$ C IDC

\begin{tabular}{|c|c|c|c|c|c|c|c|c|}
\hline $\begin{array}{l}\text { Grupo } \\
\text { familiar }\end{array}$ & D & $\mathrm{s}$ & $M$ & $E$ & D & $s$ & $M$ & E \\
\hline$I A C$ & 0 & 2 & 12 & 17 & 0 & 1.0 & 1,3 & 3.8 \\
\hline $\mathrm{D}$ & 0 & 1 & 7 & 23 & 0 & 1,0 & 1,1 & 3,8 \\
\hline$I D C$ & 0 & 3 & 7 & 18 & 0 & 1.8 & 1.6 & 3.6 \\
\hline I $A . G$ & 0 & 0 & 0 & 0 & 0 & 0 & .0 & 0 \\
\hline D. & 0 & 1 & 2 & 1 & 0 & 1,0 & 1,0 & 3,0 \\
\hline$I D C$ & 0 & 2 & 1 & 0 & 0 & 2,5 & 2.0 & 0 \\
\hline IAS & 0 & 2 & 3 & 1 & 0 & 1,0 & 2,0 & 4.0 \\
\hline$D$ & 0 & 0 & 0 & 2 & 0 & 0 & 0 & 4.0 \\
\hline$I D C$ & 0 & 6 & 8 & 2 & 0 & 2,0 & 2,5 & 3,7 \\
\hline$I A G$ & 0 & 1 & 4 & 1 & 0 & 1,0 & 2,2 & 6.0 \\
\hline$D$ & 0 & 0 & 8 & 2 & 0 & 0 & 1,4 & 3,5 \\
\hline$I D G$ & 0 & 5 & 27 & $s$ & 0 & 1,0 & 1,6 & 5,0 \\
\hline I AG & 3 & 21 & 7 & 0 & 1,0 & 1,7 & 1,5 & 0 \\
\hline$D$ & 0 & 30 & 5 & 2 & 0 & 2.0 & 1,7 & 2,7 \\
\hline I DG & 9. & 77 & 11 & 2 & 1,0 & 2,0 & 1,8 & 3,5 \\
\hline IAG & $0^{\circ}$ & 0 & 0 & 4 & 0 & 0 & 0 & 1,6 \\
\hline$D$ & 0 & 2 & 0 & 1 & 0 & 3,0 & 0 & 1,0 \\
\hline$I D C$ & 5 & 4 & 3 & 18 & 1,0 & 1,0 & 1,7 & 1,9 \\
\hline IAG & 3 & 8 & 5 & 6 & 2,0 & 1,1 & 1,4 & 4,2 \\
\hline$D$ & 3 & 10 & 11 & 8 & 1,0 & 1,4 & 1,5 & 3,4 \\
\hline IDG & 6 & 37 & 25 & $B$ & 1,0 & 1,5 & 1,6 & 3,5 \\
\hline I AG & 28 & 2 & 1 & 0 & 1,0 & 3,7 & 0 & 0 \\
\hline$D$ & 26 & 10 & 0 & 0 & 1,0 & 2,6 & 0 & 0 \\
\hline I DG & 84 & 14 & 0 & 0 & 1,0 & 3,6 & 0 & 0 \\
\hline IAS & 0 & 2 & 8 & 2 & 0 & 1,0 & 1,2 & 2.8 \\
\hline$D$ & 0 & 1 & 9 & 1 & 0 & 1,0 & 1,6 & 2.0 \\
\hline$I D G$ & 0 & 10 & 18 & 8 & 0 & 1,5 & 1,8 & 2,7 \\
\hline I AC & 0 & 1 & 10 & 7 & 0 & 1,0 & 1,0 & 3,8 \\
\hline$D$ & 0 & $0^{-}$ & 8 & 3 & 0 & 0 & 1,0 & 6,8 \\
\hline IDG & 0 & 6 & 7 & 12 & 0 & 3,0 & 1,4 & 4,2 \\
\hline I AG & 0 & 4 & 14 & 6 & 0 & 1,0 & 1,6 & 3,0 \\
\hline$D$ & 0 & $s$ & 9 & 18 & 0 & 1,2 & 1,4 & 3,1 \\
\hline IDG & 0 & 5 & 12 & $s$ & 0 & 1,4 & 1,9 & 2,0 \\
\hline IAG & 0 & 17 & 9 & 2 & 0 & 1,5 & 1,8 & 5,5 \\
\hline$D$ & 0 & 11 & 16 & 7 & 0 & 1,2 & 2,4 & 4,0 \\
\hline$f x_{i}$ & 7 & 66 & 19 & 3 & 1,0 & 2,0 & 1,8 & 4,3 \\
\hline IAC & .2 & 4 & 2 & 0 & 1,0 & 1,5 & 2,0 & 0 \\
\hline$D$ & 1 & 3 & 1 & 9 & 1,0 & 1,7 & 1.0 & 2,3 \\
\hline נD I I & 7 & 13 & 11 & 12 & 1,0 & 2,4 & 1,4 & 3,1 \\
\hline I AO & 17 & 7 & 3 & 3 & 1,0 & 2,1 & 1,3 & 4,0 \\
\hline 0 & is & 15 & 6 & 1 & 1,0 & 2,2 & 1,7 & 1,0 \\
\hline I CC & $\square 0$ & 28 & $s$ & 1 & 1,0 & 2,8 & 1,4 & 6,0 \\
\hline IAC & 3 & 4 & 6 & 4 & 1,0 & 2,1 & 1,7 & 3,0 \\
\hline 0 & 3 & 8 & 3 & 4 & 1,0 & 1,9 & 1,7 & 2.2 \\
\hline ILC & 17 & 32 & 15 & 10 & 1,0 & 2,2 & 2,6 & 2,8 \\
\hline ISO & 0 & 3 & 3 & 10 & 0 & 1,3 & 1,7 & 2,0 \\
\hline 6 & 0 & 3 & 3 & 7 & 0 & 1,2 & 1,0 & 2,1 \\
\hline$!: \cdots$ & $i^{\prime}$ & 4 & $s$ & 6 & 0 & 1,5 & 1,6 & 3,6 \\
\hline$!:{ }^{\prime}$ & $\therefore$ & 3 & 3 & 0 & 0 & 1,8 & 1,7 & 0 \\
\hline$!$ & l & 10 & 8 & 3 & 1,0 & 1,6 & 1,0 & 4,0 \\
\hline $1 \ldots \ldots$ & : & 20 & $d g$ & 0 & 1,0 & 1,0 & 1,6 & 3,8 \\
\hline
\end{tabular}




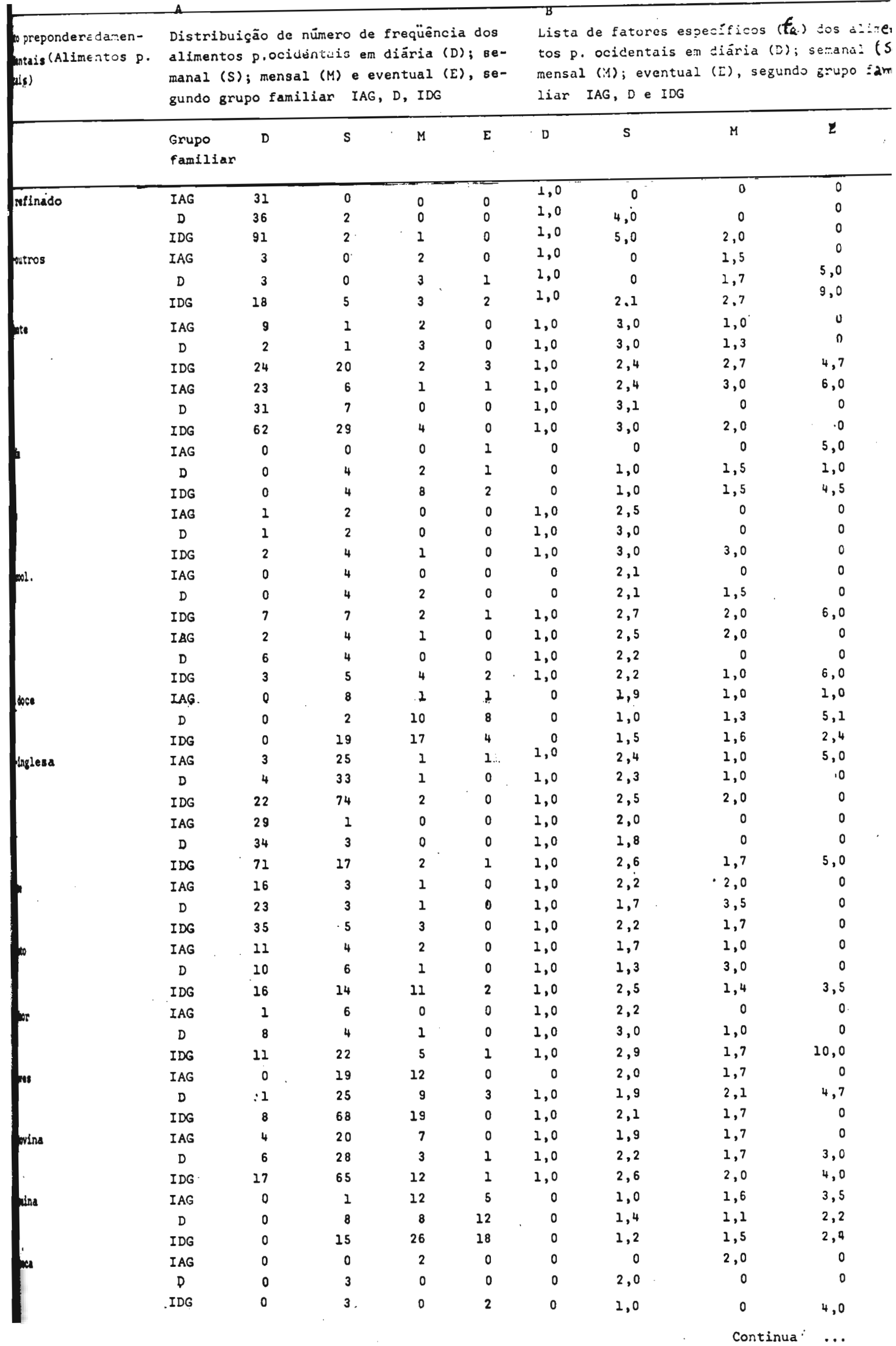




\begin{tabular}{|c|c|c|c|c|c|c|c|c|c|}
\hline \multirow{3}{*}{$\begin{array}{l}\text { Fuaçä... } \\
\text { to preponderadamen- } \\
\text { Yentuis (Alimentos } \\
\text { katais) }\end{array}$} & \multicolumn{9}{|l|}{ A } \\
\hline & \multicolumn{5}{|c|}{$\begin{array}{l}\text { Distribuigāo de nümero de frequēncia dos ali- } \\
\text { mentos p.ocidentals em diäria (D); semanal } \\
\text { (S); mensal (M) e eventual (E), segundo grupo } \\
\text { familiar IAG, D.e IDG. }\end{array}$} & \multicolumn{4}{|c|}{$\begin{array}{l}\text { Lista de fatores específicos(f dos alime: } \\
\text { p.ocidentals em diäria (D); semanal (S) } \\
\text { mensal (M); eventual (E), segundo grupo } \\
\text { miliar IAG, D e IDG. }\end{array}$} \\
\hline & $\begin{array}{l}\text { Grupo } \\
\text { familiar }\end{array}$ & D & $s$ & $M$ & $E$ & D & s & $M$ & $E$ \\
\hline \multirow[t]{2}{*}{ 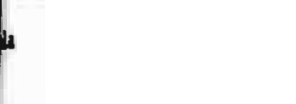 } & IAG & 23 & 6 & 1 & 0 & 1,0 & 2,3 & 2,0 & 0 \\
\hline & $\mathrm{D}$ & 31 & 2 & 0 & 0 & 1,0 & 3,5 & 0 & 0 \\
\hline \multirow{3}{*}{ 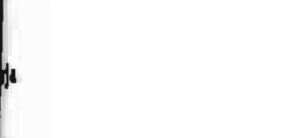 } & IDG & 81 & 17 & 0 & 0 & 1,0 & 2,9 & 0 & 0 \\
\hline & IAG & 0 & 4 & 6 & 8 & 0 & $i, 0$ & 1,9 & 3,0 . \\
\hline & $D$ & 2 & 4 & 9 & 7 & 1,0 & 2,1 & 1,3 & 3,1 \\
\hline \multirow{3}{*}{ Late } & IDG & 3 & 28 & 18 & 12 & 1,0 & 1,8 & 1,7 & 3,4 \\
\hline & IAG & 2 & 2 & 2 & 1 & 1,0 & 2,2 & 1,5 & 1,5 \\
\hline & D & 2 & 10 & 3 & 1 & 1,0 & 3,0 & 2,3 & 4,0 \\
\hline \multirow{3}{*}{ entos- } & IDG & 6 & 18 & 7 & 1 & 1,0 & 1,7 & 1,7 & 3,0 \\
\hline & IAG & 0 & 1 & 7 & 5 & 0 & 1,5 & 1,9 & 4,0 \\
\hline & $D$ & 0 & 4 & 9 & 5 & 0 & 1,0 & 2,0 & 6,0 \\
\hline \multirow{4}{*}{ do leite } & IDG & 0 & 3 & 2 & 5 & 0 & 2,7 & 3,0 & 3,5 \\
\hline & IAG & 0 & 1 & 3 & 5 & 0 & 1,0 & 1,0 & 4,2 \\
\hline & D & 0 & 2 & 7 & 9 & 0 & 1,0 & 1,3 & 2,7 \\
\hline & IDG & 0 & 3 & 12 & 10 & 0 & 1,0 & 1,4 & 4,2 \\
\hline \multirow{3}{*}{ Solos- } & IAG & 0 & 9 & 10 & 4 & 0 & 1,1 & 1,2 & 3,7 \\
\hline & $D$ & 0 & 20 & 11 & 3 & 0 & 1,5 & 1,5 & 3,7 \\
\hline & IDG & 0 & 31 & 34 & 21 & 0 & 1,8 & 1,5 & 3,6 \\
\hline \multirow[t]{3}{*}{ is } & IAG & 0 & 1 & 3 & 0 & 0 & 2,0 & 1,7 & 0 \\
\hline & D & 0 & 0 & 3 & 2 & 0 & 0 & 1,0 & 3,5 \\
\hline & IDG & 0 & 5 & 2 & 1 & 0 & 1,8 & 1,0 & 4,0 \\
\hline \multirow[t]{3}{*}{ undioca } & IAG & $\dot{0}$ & 0 & 0 & 4 & 0 & ${ }_{0}$ & 0 & 5,0 \\
\hline & D & 0 & 1 & 4 & 4 & 0 & 1,0 & 1,0 & 3,5 \\
\hline & IDG & 0 & 0 & 0 & 4 & 0 & 0 & 0 & 2,7 \\
\hline \multirow[t]{3}{*}{ trigo } & IAG & 4 & 23 & 2 & 0 & 1,0 & 2,6 & 1,5 & 0 \\
\hline & D & 2 & 22 & 4 & 1 & 1,0 & 2,7 & 2,0 & 5,5 \\
\hline & IDG & 10 & 66 & 8 & 0 & 1,0 & 2,4 & 1,9 & 0 \\
\hline \multirow[t]{3}{*}{ is } & IAG & 9 & 15 & 4 & 0 & 1,0 & 2,2 & 1,2 & 0 \\
\hline & D & 22 & 13 & 3 & 0 & 1,0 & 2,7 & 2,0 & 0 \\
\hline & IDG & 17 & 56 & 20 & 1 & 1,0 & 2,4 & 1,7 & 2,0 \\
\hline \multirow[t]{6}{*}{10} & IAG & 0 & 0 & 2 & 1 & 0 & 0 & 1,0 & 1,0 \\
\hline & $\mathrm{D}$ & 0 & 0 & 3 & 3 & 0 & 0 & 1,0 & 1,0 \\
\hline & IDG & 0 & 0 & 4 & 7 & 0 & 0 & 1,0 & 2,0 \\
\hline & IAG & 0 & 2 & 1 & 1 & 0 & $1 ; 5$ & 1,5 & 1,0 \\
\hline & D & 0 & 5 & 2 & 2 & 0 & 1,6 & 1,5 & 1,5 \\
\hline & IDG & 0 & 1 & 2 & 2 & 0 & 1,0 & 1,7 & 2,5 \\
\hline \multirow[t]{3}{*}{ me } & IAG & 1 & 2 & 4 & 1 & $i, 0$ & 1,0 & 2,7 & 6,0 \\
\hline & D & 1 & 10 & 10 & 4 & 1,0 & 1,3 & 1,8 & 4,2 \\
\hline & IDG & 1 & 15 & 15 & 5 & 1,0 & 1,5 & 2,5 & 3,0 \\
\hline \multirow{3}{*}{ Linosa- } & IAG & 0 & 0 & 1 & 0 & 0 & 0 & 1,0 & 0 \\
\hline & $D$ & 0 & 0 & 1 & 0 & 0 & 0 & 1,0 & 0 \\
\hline & $I D G$ & 0 & 0 & 0 & 0 & 0 & 0 & 0 & 0 \\
\hline a condersado & IAG & 1 & 2 & 7 & 6 & 1,0 & 1,5 & 2,0 & 4,2 \\
\hline & $D$ & 1 & 9 & 17 & 6 & 1,0 & 1,4 & 1,6 & 4,5 \\
\hline & IDG & 1 & 17 & 34 & 14 & 1,0 & 1,2 & 1,5 & 3,6 \\
\hline to fresco & IAG & 9 & 7 & 7 & 1 & 1,0 & 2,4 & 2,0 & 5,5 \\
\hline & $D$ & 10 & 10 & 5 & 3 & 1,0 & 2,2 & 1,6 & 4,0 \\
\hline & $I D G^{\prime}$ & 37 & 19 & 4 & 1 & 1,0 & 2,3 & 1,7 & 4,0 \\
\hline in ex pó & IAG & 8 & 5 & 1 & 1 & 1,0 & 1,9 & 2,0 & 5,0 \\
\hline & $D$ & 15 & 9 & 3 & 1 & 1,0 & 2,5 & 2,0 & 6,0 \\
\hline & $I D G$ & 24 & 17 & 7 & 1 & 1,0 & 2,0 & 1,3 & 5,0 \\
\hline
\end{tabular}




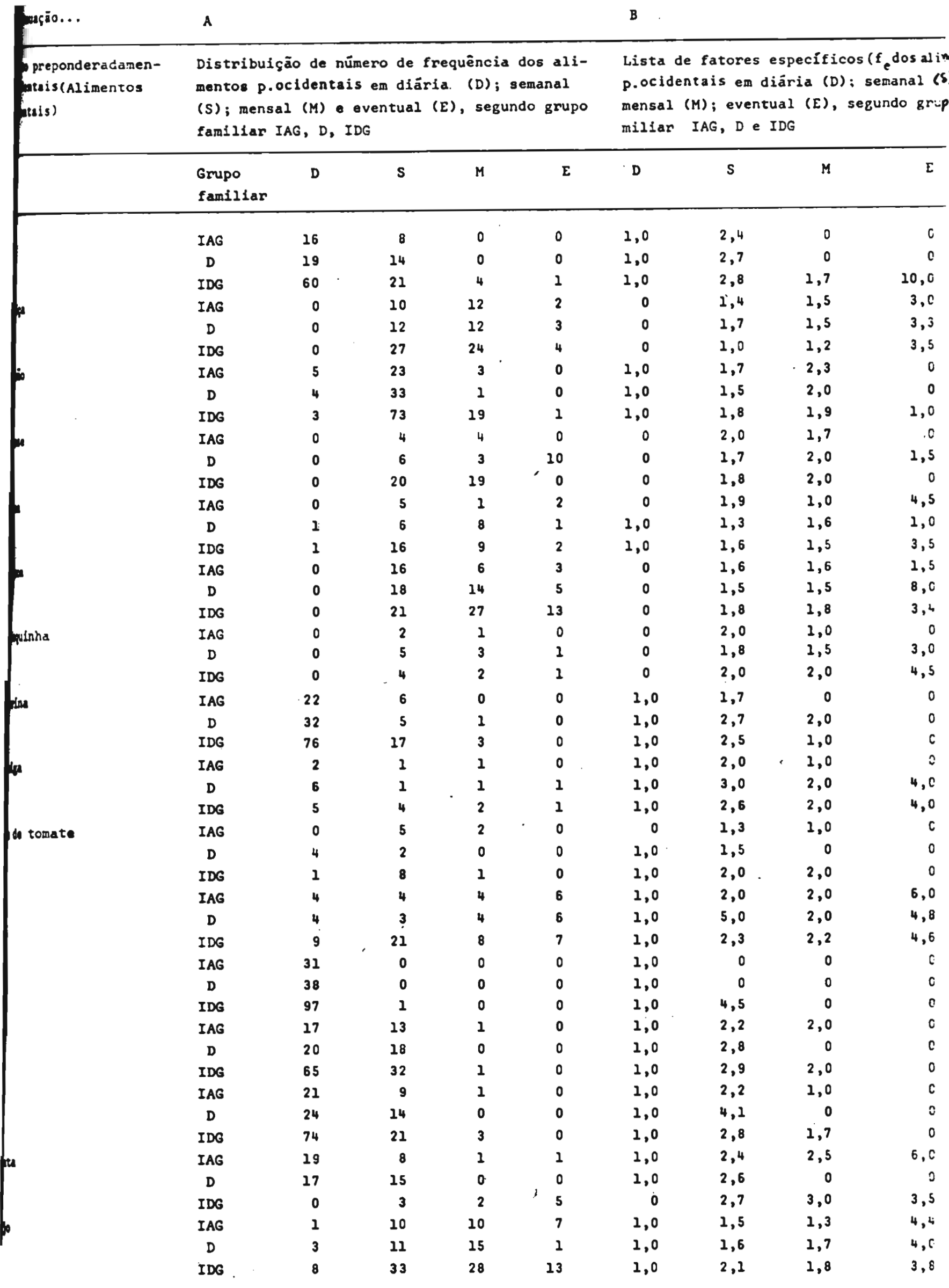




\begin{tabular}{|c|c|c|c|c|c|c|c|c|c|}
\hline dinuaçāo ... & A & & & & & B & & & \\
\hline \multirow[t]{2}{*}{$\begin{array}{l}\text { wto preponderadamen- } \\
\text { fdentais (Alimentos } \\
\text { didentais) }\end{array}$} & \multicolumn{5}{|c|}{$\begin{array}{l}\text { Distribuiçāo de número de frequência dos ali- } \\
\text { mentos p.ocidentais em diāria (D); semanal } \\
\text { (S); mensal (M) e eventual (E), segundo grupo } \\
\text { familiar IAG, D, IDG }\end{array}$} & \multicolumn{4}{|c|}{$\begin{array}{l}\text { Lista de fatores especificos ( } f_{e} \text { dos al } \\
\text { p. ocidentais em diária (D); semanal (s } \\
\text { mensal (M); eventual (E), segundo gru: } \\
\text { miliar IAG, D, IDG. }\end{array}$} \\
\hline & $\begin{array}{l}\text { Grupo } \\
\text { familiar }\end{array}$ & D & $\mathrm{s}$ & M & $\mathbf{E}$ & D & s & $M$ & E \\
\hline \multirow[t]{3}{*}{ igorante } & IAG & 3 & 6 & 10 & 9 & 1,0 & 1,5 & 1,9 & 3,8 \\
\hline & $\mathrm{D}$ & 2 & 13 & 16 & 5 & 1,0 & 1,8 & 1,3 & 4,4 \\
\hline & IDG & 10 & 29 & 24 & 12 & 1,0 & 2,3 & 1,5 & 3,7 \\
\hline \multirow[t]{3}{*}{ Heha } & IAG & 0 & 8 & 11 & 1 & 0 & 1,0 & 1,1 & 1,5 \\
\hline & D & 0 & 14 & 8 & 5 & 0 & 1,0 & 1,2 & 3,4 \\
\hline & IDG & 0 & 54 & 21 & 3 & 0 & 1,0 & 1,2 & 4,3 \\
\hline \multirow[t]{3}{*}{ de frutas } & IAG & 8 & 16 & 1 & 0 & 1,0 & 2,5 & 1,0 & 0 \\
\hline & D & 5 & 20 & 8 & 1 & 1,0 & 2,9 & 1,7 & 5,0 \\
\hline & IDG & 15 & 53 & 10 & 3 & 1,0 & 2,6 & 1,7 & 4,0 \\
\hline \multirow[t]{3}{*}{ pre } & IAG & 10 & 13 & 1 & 0 & 1,0 & 2,1 & 1,0 & 0 \\
\hline & D & 14 & 13 & 2 & 2 & 1,0 & 2,5 & 2,0 & 8,0 \\
\hline & IDG & 20 & 33 & 8 & 3 & 1,0 & 2,8 & 2,0 & 2,0 \\
\hline
\end{tabular}




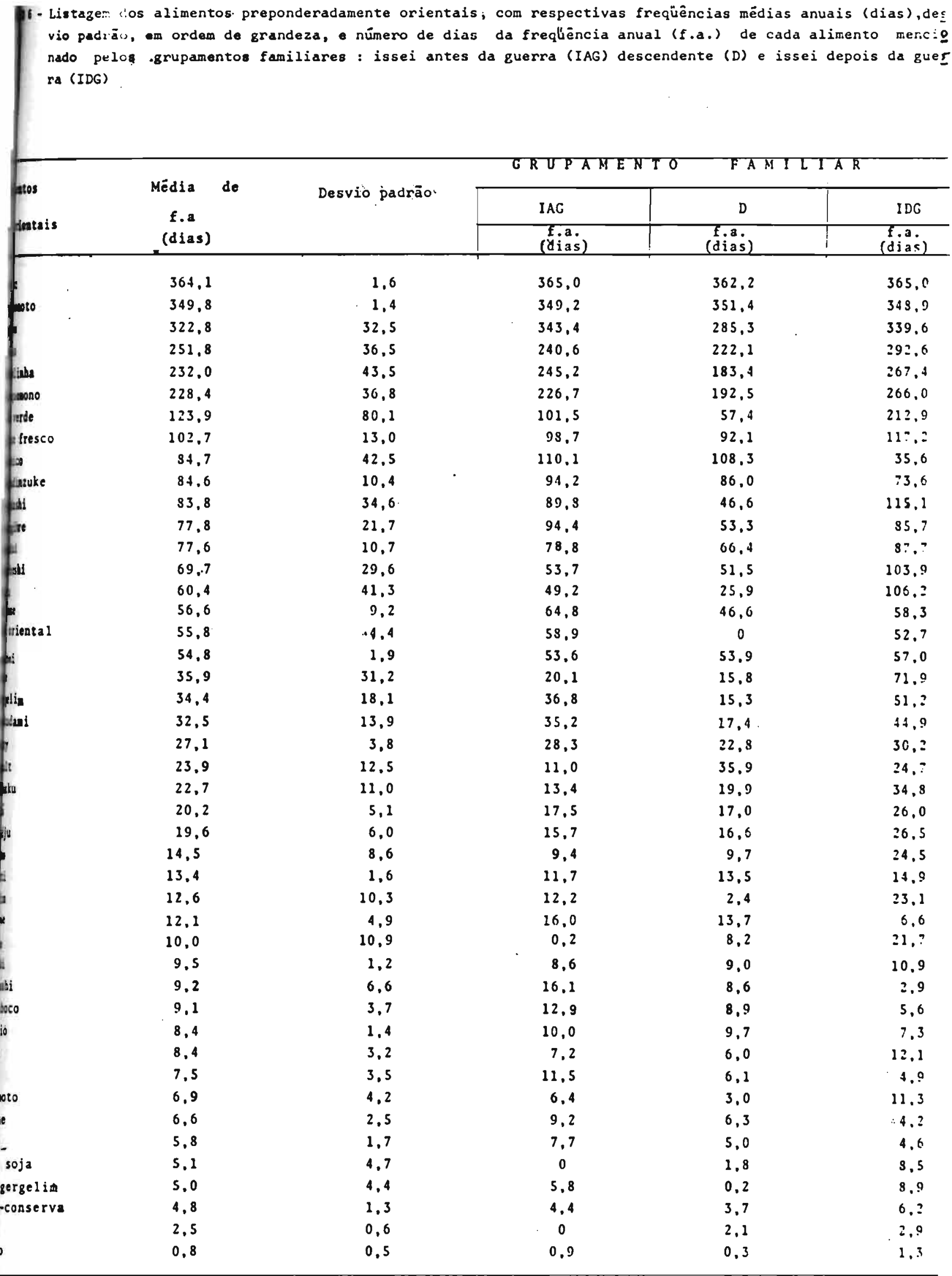




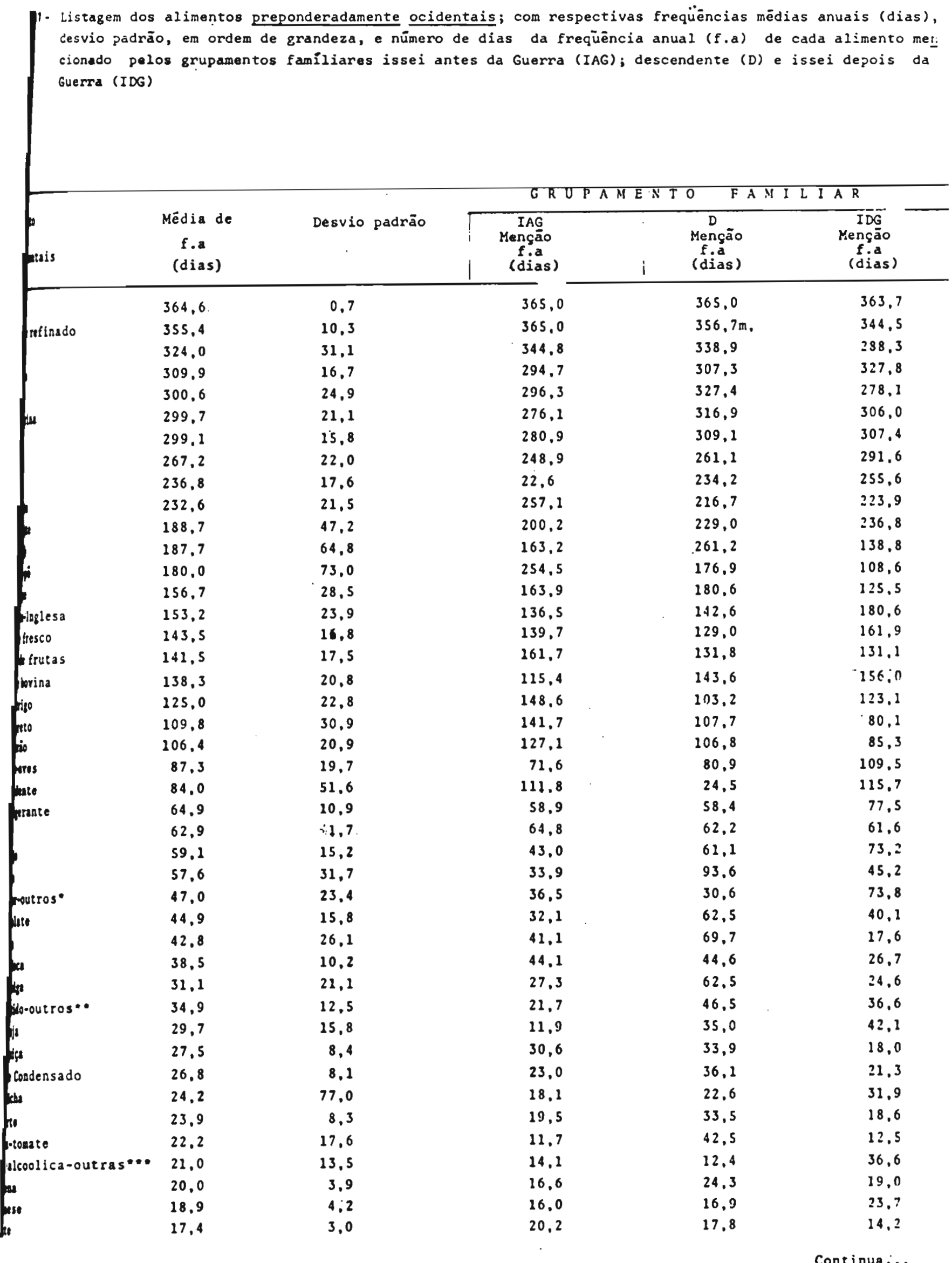




\begin{tabular}{|c|c|c|c|c|c|}
\hline toos & $\begin{array}{l}\text { Média de } \\
\text { f.a } \\
\text { (dias) }\end{array}$ & Desvio padrão & $\begin{array}{c}\text { IAG } \\
\text { Mençăo } \\
\text { f.a } \\
\text { (dias) }\end{array}$ & $\begin{array}{c}\text { D } \\
\text { Mençāo } \\
\text { f a } \\
\text { (dias) }\end{array}$ & $\begin{array}{c}\text { IDG } \\
\text { Menç̃̃o } \\
\text { f.a } \\
\text { (dias) }\end{array}$ \\
\hline doce & 17,4 & 9,0 & 25,9 & 7,9 & 18,5 \\
\hline stina & 14.4 & 4,6 & 9,7 & 18.8 & 14.8 \\
\hline puinha & 8,6 & 4,7 & 7.1 & 13.8 & 4.8 \\
\hline mato-outros $\cdots$ & 8,5 & 3,3 & 8.3 & 11.9 & $5,2=$ \\
\hline & 7,0 & 5,2 & 5,6 & 11.3 & 1.0 \\
\hline de leite & 4.6 & 1.4 & 3,5 & 6.2 & 4,1 \\
\hline H & 3.8 & 2.4 & 5.3 & 1,1 & 5,1 \\
\hline win & 3,4 & 3.1 & 0.2 & 6.4 & 3.7 \\
\hline seca & 3.2 & 4.3 & 0.8 & 8,2 & 0,6 \\
\hline undioca a & 1.2 & 1,5 & 0.6 & 3,0 & 0.1 \\
\hline & 0.8 & 0.2 & 0.8 & 1,0 & 0.6 \\
\hline Sosas-outras - * * & 0.3 & 0.1 & 0.4 & 0.3 & 0.0 \\
\hline
\end{tabular}

Afücar zoutros. (Eristal, mascavo z. glauçücar).

Eabutidos-outras (presunto, salame, mortadela, presuntada).

Beb. Alcool.-outras (wiski, vinho).

Condimento-outros (orëgano, salsa, hortelä).

- leguminosas-outras (grāo-de-bico, lentilha). 
ANEXO $\therefore 8$ - Idade méd1a dos chefes-de-famflia dos grupos fam1liares IAG, D e IDG

\begin{tabular}{|c|c|c|c|c|c|}
\hline \multirow{2}{*}{\multicolumn{2}{|c|}{ Falxa etária }} & \multicolumn{3}{|c|}{ Chefe-de-famflia } & \multirow{2}{*}{$\begin{array}{l}\text { TOTAL de } \\
\therefore \text {-1dades }\end{array}$} \\
\hline & & $n$ & $($ chefe-de-famflia:.x $n)+(\ldots)+$ & $\ldots$ & \\
\hline 40 & IAG $_{5}$ & 2 & $\therefore(41 \dot{x} 1)+(45 \times 1)$ & $=$ & 86 \\
\hline & -50 & $\therefore 3$ & $(47 \times 2)+(45 \times 1)$ & $=$ & 143 \\
\hline & -55 & 4 & $(51 \times 1)+(53 \times 1)+(54 \times 1)+(55 \times 1)$ & $=$ & 213 \\
\hline & -60 & 11 & $(56 \times 1)+(57 \times 4)+(58 \times 2)+(59 \times 3)+(60 \times 1)$ & $=$ & 637 \\
\hline \multirow[t]{3}{*}{61} & e mais & 11 & $(61 \times 2)+(64 \times 2)+(65 \times 1)+(66 \times 2)+(67 \times 1)+$ & & \\
\hline & & & $+(71 \times 1)+(72 \times 1)+(76 \times 1)$ & $=$ & 733 \\
\hline & & 31 & & & $1812 a$ \\
\hline
\end{tabular}

Idade média dos chefes-de-familia IAG 58,4 anos

\begin{tabular}{|c|c|c|c|c|}
\hline & $D$ & & & \\
\hline & -35 & 5 & $(31 \times 2)+(32 \times 1)+(34 \times 1)+(35 \times 1)$ & $=163$ \\
\hline 36 & -40 & 14 & $(35 \times 1)+(36 \times 4)+(37 \times 6)+(39 \times 3)+(35 \times 1)$ & $=523$ \\
\hline 41 & -45 & 8 & $(41 \times 1)+(42 \times 2)+(43 \times 3)+(44 \times 2)$ & $=342$ \\
\hline 46 & -50 & 8 & $(46 \times 2)+(47 \times 2)+(48 \times 2)+(49 \times 1)+(50 \times 1)$ & $=381$ \\
\hline \multirow[t]{3}{*}{51} & -55 & 3 & $(51 \times 1)+(52 \times 1)+(55 \times 1)$ & $=158$ \\
\hline & & 38 & . & 1567 anos \\
\hline & & Id & de média dos chefes-de-familia $D$ & 2 anos \\
\hline \multicolumn{2}{|c|}{ IDG } & & & \\
\hline 25 & -30 & 5 & $(28 \times 1)+(29 \times 3)+(30 \times 1)$ & $=145$ \\
\hline 31 & -35 & 8 & $(31 \times 2)+(32 \times 1)+(34 \times 2)+(35 \times 3)$ & $=267$ \\
\hline 36 & -40 & 16 & $(36 \times 2)+(37 \times 4)+(38 \times 3)+(39 \times 2)+(40 \times 5)$ & 612 \\
\hline 41 & -45 & 15 & $(41 \times 7)+(42 \times 1)+(43 \times 2)+(44 \times 2)+(45 \times 3)$ & $=638$ \\
\hline 46 & -50 & 17 & $(46 \times 2)+(47 \times 5)+(48 \times 4)+(49 \times 3)+(50 \times 3)$ & $=816$ \\
\hline 51 & $=55$ & 11 & $(51 \times 4)+(54 \times 4)+(53 \times 2)+(55 \times 1)$ & $=581$ \\
\hline 56 & -60 & 7 & $(56 \times 1)+(57 \times 3)+(58 \times 1)+(59 \times 2)$ & $=403$ \\
\hline & e mals & 19 & $(61 \times 2)+(62 \times 2)+(63 \times 3)+(64 \times 1)+(65 \times 1)+$ & \\
\hline & & & $+(66 \times 5)+(67 \times 1)+(68 \times 1)+71 \times 1)+73 \times 1)+$ & \\
\hline & & & $+(77 \times 1)$ & $=1250$ \\
\hline & & 98 & & 4712 anos \\
\hline
\end{tabular}

Idade média dos chefes-de-fam1lia IDQ 48,0 , anos 
ANEXo 9- Distribuição percentual do grau de escolaridade dos chefes-de-familia, estratificados em IAG,D e IDG

\begin{tabular}{|c|c|c|c|c|c|c|c|c|c|}
\hline \multirow[t]{2}{*}{ Chefes-de-famllia } & \multicolumn{2}{|c|}{$1 \&$ Grau } & $5-8$ & \multirow{2}{*}{$\frac{\text { séries }}{\%}$} & \multirow{2}{*}{$2^{29}$} & \multirow{2}{*}{$\begin{array}{c}\text { Grau } \\
\% \\
\%\end{array}$} & \multicolumn{2}{|c|}{$\begin{array}{l}\text { Grau } \\
\text { Superior }\end{array}$} & \multirow{2}{*}{ TOTAL } \\
\hline & $n$ & $\%$ & $n$ & & & & $n$ & $\%$ & \\
\hline & & & & & & & & & - \\
\hline IAG & 21 & 67.7 & 6 & 19.4 & 4 & 12,9 & 0 & - & 31 \\
\hline $\mathrm{D}$ & 27 & 71,1 & 8 & 21,0 & 3 & 7,9 & 0 & - & 38 \\
\hline IDG & 21 & 21,4 & 39 & 39,9 & 36 & 36.7 & 2 & 2,0 & 98 \\
\hline TOTAL & 69 & 41,4 & 53 & 31.7 & 43 & 25.7 & 2 & $1: 2^{-}$ & $167100 \%$ \\
\hline
\end{tabular}

NEXO 10 - Tempo de residência dos chefes-de-família, estratificados em grupos IAG.D. e. IDG, nos municípios em éstudo

\begin{tabular}{|c|c|c|c|c|c|c|c|c|c|}
\hline \multirow{2}{*}{$\begin{array}{l}\text { Tempo de } \\
\text { residência } \\
\text { (anos) }\end{array}$} & \multicolumn{3}{|c|}{ IAG } & \multicolumn{3}{|c|}{$\mathrm{D}$} & \multicolumn{3}{|c|}{ IDG } \\
\hline & $\mathrm{n}$ & $\%$ & $\% a c$. & $\mathrm{n}$ & $\%$ & $\% a c$. & $\mathrm{n}$ & $\%$ & $\% a c$. \\
\hline $5-9$ & 10 & 32,3 & 32,3 & 7 & 18,4 & 18,4 & 26 & 26,5 & 26.5 \\
\hline $10-14$ & 6 & 19.3 & 51.6 & 4 & 10.5 & 28,9 & 11 & 11,3 & 37.8 \\
\hline $15-19$ & 9 & 29.0 & 80,6 & 7 & 18,4 & 47.3 & 30 & 30.6 & 68,4 \\
\hline $20-24$ & 2 & 6.5 & 87,1 & 7 & 18.4 & 65.7 & 29 & 29.6 & 98.0 \\
\hline 25 e mais & 4 & 12,9 & 100,0 & 13 & 34,3 & 100.0 & 2 & 2.0 & 100.0 \\
\hline
\end{tabular}


ANEXO 11 - Distribuição da ārea total das propriedades em alqueire* e área utilizada para produção, segundo famílias, 1981

\section{Area em} alqueire

(a)
Area total de propriedade Familia

n
\&

Área utilizada para produção Familia \&

$\Omega$

\begin{tabular}{|c|c|c|c|c|}
\hline até 1 a & 9 & 5,3 & 28 & 16,6 \\
\hline $1+2 a$ & 11 & 6,5 & 50 & 29,6 \\
\hline $2+3 a$ & 46 & 27,3 & 37 & 22,0 \\
\hline $3 \vdash 4 a$ & 22 & 13,0 & 17 & 10,0 \\
\hline $41-5 a$ & 26 & 15,4 & 16 & 9,5 \\
\hline $5 \vdash 6$ a & 14 & 8,3 & 8 & 4,7 \\
\hline $6 \vdash 7 a$ & 7 & 4,1 & 4 & 2,4 \\
\hline $7 \vdash 8 a$ & 7 & 4,1 & 2 & 1,2 \\
\hline $8 \vdash 9 a$ & 9 & 5,3 & 2 & 1,2 \\
\hline $9 \vdash 10 a$ & 1 & 0,6 & - & - \\
\hline $10 \vdash 20 a$ & 15 & 8,9 & 4 & 2,4 \\
\hline $201-30 \mathrm{a}$ & 1 & 0,6 & - & - \\
\hline det 30 a & 1 & 0,6 & - & - \\
\hline sem informação & - & - & 1 & 0,6 \\
\hline
\end{tabular}

* Alqueire paulista, la $=24.200 \mathrm{~m}^{2}$. 
AIIIXO 12 - Tipos de produção agrícola, 1981

Tipo de Produção

Família

$n$

\begin{tabular}{lcc}
\hline Flores & 47 & 27,8 \\
frutas & 27 & 16,0 \\
flores e frutas & 22 & 13,0 \\
verduras & 8 & 4,7 \\
flores e verduras & 4 & 2,4 \\
frutas e verduras & 28 & 16,6 \\
flores, frutas e verduras & 6 & 3,6 \\
avicultura & 5 & 3,0 \\
avicultura e flores & 1 & 0,6 \\
avicultura e frutas & 3 & 1,8 \\
avicultura, flores e frutas & 2 & 1,2 \\
avicultura, frutas e verduras & 1 & 0,6 \\
outros* & 9 & 5,3 \\
sem produção (empregados) & 4 & 2,4 \\
sem informação & 2 & 1,2 \\
& & 100,0 \\
\hline
\end{tabular}

*outros -atividade comercial e agrícola. 
Arveyo 13 - Condições de posse da terra

Condiçōes de posse

Familia

$\%$

$\mathrm{n}$

própria pago

144

85,2

própria em aquisiçāo

3

1,8

parceiro

2

1,2

meeiro

8

4,7

empregado

4

2,4

arrendado

3

1,8

cedido

sem informação

4

2,4

1

0,6

ANEXO $14^{-}$Tipos de contrução de moradia das propriedades rurais estudadas

Tipos utilizadas para cons- Familia trução de moradia n

$$
\text { tijolo ou bloco }
$$

madeira

misto (tijolo e madeira)

149

88,2

19

11,2

1

0,6 
ANEXX 15 - Distribuição de número de cômodoš das residências segundo famillas

\begin{tabular}{lcc}
\hline $\begin{array}{c}\text { Cômodos } \\
n\end{array}$ & Familias & 8 \\
\hline 2 & $n$ & \\
3 & 1 & 0,6 \\
4 & 7 & 4,1 \\
5 & 15 & 8,9 \\
6 & 30 & 17,8 \\
7 & 29 & 17,2 \\
8 & 21 & 12,4 \\
9 & 17 & 10,1 \\
10 & 25 & 14,8 \\
11 & 7 & 4,1 \\
12 & 7 & 4,1 \\
14 & 5 & 3,0 \\
15 & 3 & 1,8 \\
sem informação & 1 & 0,6 \\
$\cdots$ & 1 & 0,6 \\
\hline ToTAL & 169 & 100,0 \\
\hline
\end{tabular}

OBS: Não houve famílias com 13 cômodos. * V1de ANexo 3. 


$$
\text { ANEXO - } 16
$$

Distribuição dos tipos de abastecimento d'água, revestimento do poço e instalação bomba-d.' água, 'segundó familias

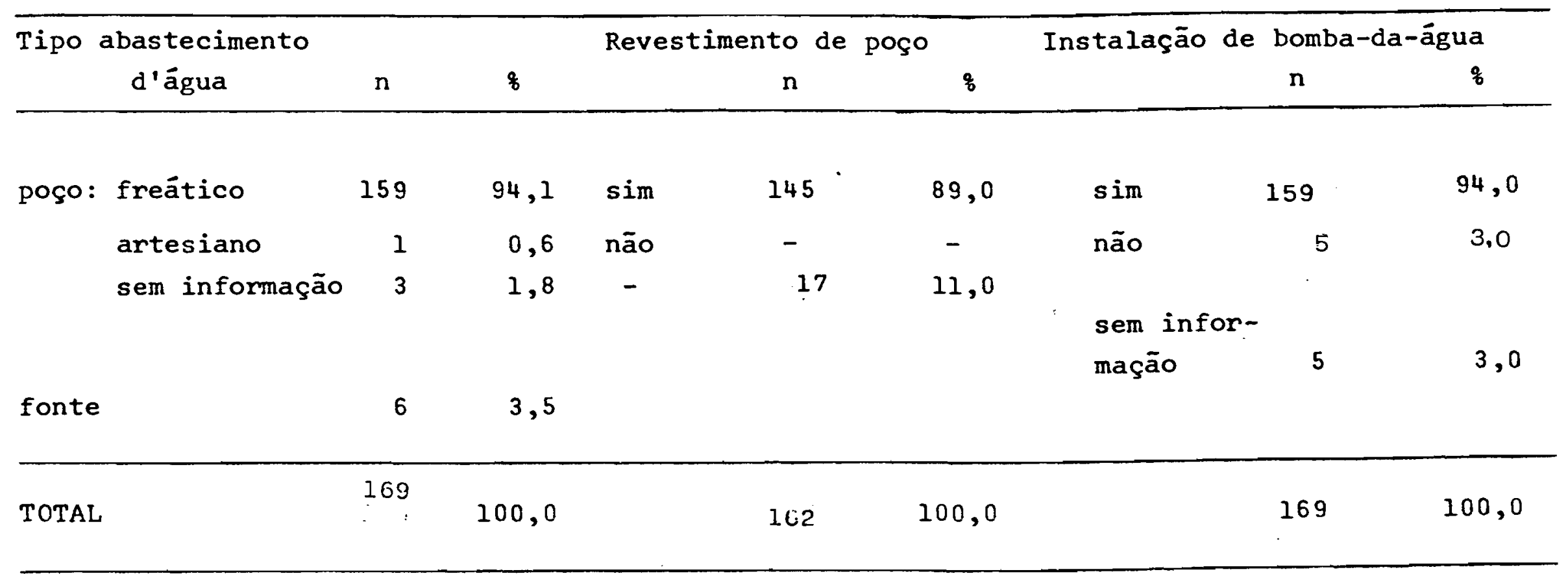


ANEXO 17 - Número de sanitários, com e sem descarga, segundo loca lização dentro e fora de casa, entre famílias estuda das

\begin{tabular}{|c|c|c|c|c|c|c|}
\hline \multirow[b]{2}{*}{ Sanitārios } & \multicolumn{2}{|c|}{ Sem descarga } & \multicolumn{4}{|c|}{ Com descarga } \\
\hline & Fora de & asa & Dentro de & casa & Fora de & casa \\
\hline & Famílias & & Familias & & Famílias & \\
\hline$n$ & $n$ & 8 & $n$ & 8 & $n$ & 8 \\
\hline 0 & 83 & 49,1 & 87 & 51,5 & 122 & 72,2 \\
\hline 1 & 84 & 49,7 & 67 & 39,6 & 41 & 24,3 \\
\hline 2 & 2 & 1,2 & 15 & 8,9 & 5 & 3,0 \\
\hline 3 & - & - & - & - & 1 & 0,6 \\
\hline TOTAL & 169 & 100,0 & 169 & 100,0 & 169 & 100,0 \\
\hline
\end{tabular}




\section{GLOSSARIO DE ALIMENTOS ORIENTAIS}

Agué

Ajinomoto

Azuki

Bardana

Broto de samambaia- Pteridium aquilinum KUHN var. latiusculion UNDERWOOD.

Chá oriental

Chã verde

Curry

Dashico

Fukundinzuke

Gengibre

Gergelim

Hondashi

Kamaboco

Kampio

- Queijo de soja, fatiado e frito.

- Glutamato monossödico.

- Leguminosa seca, Phaseolus Angularis(Willd) WIGTH.

- Raiz de Arctium Rappa L.

- Folhas desidratadas de Thea Sinensis L., mis turados com grão de cereal ou de flor de jasmim.

- Folha de chá (Thea sinensis L.), desidratada.

- Mistura de condimentos em pó (rizomas de familia de gengibre, mostarda, pimenta em pó, salsa, cuminho, canela, nóz moscada, cravo da India, pimenta vermelha).

- Peixe bem desidratado, utilizado na obtenção de extrato de peixe para preparar caldos.

- Conserva de hortaliças, salgada e curtida em shoyu.

- Rizoma de Zingiber officinale Rosc.

- Sementes de Sesamun indicum D.C.

- Glutamato de monossödio enriquecido com extrato de peixe Bonito.

- Preparado de massa de filé de peixes selecio nados; amido de milho, açúcar, sal, ajinomoto e água gelada, moldada sobre uma tira de madeira e cozida à vapor.

- Cucumis, fatiadas em forma de fita desidrata da. 
Kinaco

Kombu

Konhaku

Mandju

Menlui

Mesashi

Mirim

Misso

Motti

Natto

Nina

Nori

Okara
- Farinha de soja, tostada.

- Alga marinha Laminaria longissima MIYABE. .

- Amido extraido de Amorphophalus Konjack K. $\mathrm{KOCH}$.

- Doce japonēs, feito com uma massa de farinha de trigo recheada com duce de feijāo, cozida em banho-maria.

- Variedade de macarrōes (sarraceno, gluten de trigo, instântaneo (temperado).

- Sardinha inteira, salgada e dessecada.

- Variedade de sakê adoçado para o preparo de pratos japoneses.

- Pasta fermentada de soja que serve como extrato de caldos.

- Pasta de arroz cozido e macerado.

- Grão de soja inoculados com Bacillus subtilis (b.natto).

- Folha de Allium tuberosum ROTTLER.

- Alga marinha, Enteromorpha compressa GREV.

- Residuo dé soja, após a retirada do leite de soja.

Peixe em conserva - Paté de pescado, curtido com muito sal.

Sake

- Vinho japonès feito de arroz.

Sembei

- Bolacha japonêsa feita a base de farinha de arroz.

Shoyu

- Molho de soja obtido pela fermentaçäo por Aspergillus oryzae, e acrescidos de cloreto de sódio.

Sunomoto

- Acido acético diluido.

Tikua
- Semelhante à kamaboco,porém difere por usar na massa de peixe variedade maior de peixe. 
Tofu

Tsukudani

Tsuquemono

Umeboshi

Wakame

Yacult
- Queijo de soja obtido por meio de coágulo de leite de soja.

- Conserva de carne ou peixe cozido em shoyu e temperos.

- Conserva de verduras cruas, salgadas e/ou fermentadas em farelo de arroz e sal.

- Conserva de ameixa anã, Promus Mume SIEB. et ZUCC.

- Alga marinha, Undaria pinnatificada Sur. dessecada.

- Bebida láctea fermentada. 